


\section{DISCLAIMER}

This report was prepared as an account of work sponsored by an agency of the United States Government. Neither the United States Government nor any agency Thereof, nor any of their employees, makes any warranty, express or implied, or assumes any legal liability or responsibility for the accuracy, completeness, or usefulness of any information, apparatus, product, or process disclosed, or represents that its use would not infringe privately owned rights. Reference herein to any specific commercial product, process, or service by trade name, trademark, manufacturer, or otherwise does not necessarily constitute or imply its endorsement, recommendation, or favoring by the United States Government or any agency thereof. The views and opinions of authors expressed herein do not necessarily state or reflect those of the United States Government or any agency thereof. 


\section{DISCLAIMER}

Portions of this document may be illegible in electronic image products. Images are produced from the best available original document. 


\begin{tabular}{|c|}
\hline Printed in the United States of America. Available from \\
National Technical Information Service \\
U.S. Department of Commerce \\
5285 Port Royal Road, Springfield, Virginia 22161 \\
Price: Printed Copy $\$ 7.25 ;$ Microfiche $\$ 3.00$ \\
\hline
\end{tabular}

This report was prepared as an account of work sponsored by an agency of the United States Government. Neither the United States Government nor any agency thereof, nor any of their employees, contractors, subcontractors, or their employees, makes any warranty, express or implied, nor assumes any legal liability or responsibility for any third party's use or the results of such use of any information, apparatus, product or process disclosed in this report, nor represents that its use by such third party would not infringe privately owned rights. 
ORNL/TM-6191/V1

Dist. Category UCं-77

Contract No. W-7405-eng-26

Engineering Technology Division

HTGR BASE TECHNOLOGY PROGRAM

Prestressed Concrete Nuclear Pressure

Vessel Development (189a 01331)

Instrumentation Evaluation Studies - Milestone $7 \mathrm{~b}$

MONITORING OF PRESTRESSED CONCRETE PRESSURE VESSELS

1. AN OVERVIEW OF CONCRETE EMBEDMENT STRAIN INSTRUMENTATION

AND CALIBRATION TEST RESULTS FOR SELECTED

CONCRETE EMBEDMENT STRAIN METERS

D. J. Naus C. C. Hurtt

Manuscript Completed - May 8, 1978

Dace Published - June 1978

Prepared by the

OAK RIDGE NATIONAL LABORATORY

Oak Ridge, Tennessee 37830

operated by

UNION CARBIDE CORPORATION

for the

DEPARTMENT OF ENERGY

This report was prepared as an account of work sponsored by the United States Govermment. Neither the United States nor the United States Department of Energy, nor any of their employees, nor any of their contractors, subcontractors, or theis employees, makes liability or responsibility for the accuracy, completeness or use iuness oi any in forme or use laness ai any intormets

process disclosed, or represents
infringe privately owned rights. 
THIS PAGE

\section{WAS INTENTIONALLY \\ LEFT BLANK}


CONTENTS

$\underline{\text { Page }}$

ACKNOWLEDGMENTS . . . . . . . . . . . . . . . . . . . . . . . v v

ABSTRACT . . . . . . . . . . . . . . . . . . . . . . . 1

INTRODUCTION . . . . . . . . . . . . . . . . . . . . 2

STRAIN METERS FOR CONCRETE EMBEDMENT. . . . . . . . . . . . . 2

Performance Characteristics for PCPV Applications . . . . . 2

Design Considerations . . . . . . . . . . . . . . . . 4

Review of Measurement Techniques for Concrete

Embedment Strain Meters . . . . . . . . . . . . . . . . 7

EVALUATION OF STRAIN METERS FOR CONCRETE EMBEDMENT . . . . . . . 15

Calibration Test Specimen Geometry . . . . . . . . . . . . 15

Calibration Tests of Concrete Embedment Strain Meters . . . . 17

CONCLUSIONS . . . . . . . . . . . . . . . . . . 27

REFERENCES ....................... 113 
THIS PAGE

\section{WAS INTENTIONALLY LEFT BLANK}


ACKNOWLEDGMENTS

The planning and execution of this investigation required the assistance and cooperation of numerous people in the Solid Mechanics Section, Engineering Technology Division, and in the Y-12 Plant. The authors are indebted to those people for their cooperation and concern for the success of the investigation. A special note of appreciation is due $\mathrm{J}$. P. Callahan, T. M. Cate, H. D. Curtis, and J. E. Smith for substantial contributions during the investigation. Special thanks is also due Mrs. Ragena Foust for typing the manuscript. 


\title{
MONITORING OF PRESTRESSED CONCRETE PRESSURE VESSELS \\ 1. AN OVERVIEW OF CONCRETE EMBEDMENT STRAIN INSTRUMENTATION AND CALIBRATION TEST RESULTS FOR SELECTED CONCRETE EMBEDMENT STRAIN METERS
}
D. J. Naus
C. C. Hurtt

\begin{abstract}
Instrumentation for prestressed concrete pressure vessels (PCPVs) is required to determine strain distributions, deflections, stresses, temperature distributions, cracking magnitudes, forces in prestressing, and free moisture contents. These quantities are utilized to assess the safety and reliability of PCPVs for short- and long-term operation, the correctness of calculations and assumptions of analytical techniques, and the complex behavior of the vessels, especially their structural integrity for extended periods of time.
\end{abstract}

Numerous commercial concrete embedment instrumentation systems are available for indicating strains, stresses, loads, and moisture content. Since instrumentation is so vital in providing continuing assurance of the safe operation of the PCPVs, it is imperative that the information provided by these devices have a high degree of reliability. However, before manufacturer's claims for these systems can be accepted a priori, laboratory evaluations need to be conducted.

This report, the first of a series related to instrumentation embedded in concrete, presents results of calibration tests on strain meters. The approach was divided into two phases: (1) an overview of meter performance criteria for PCPV applications and techniques for strain measurements in concrete and (2) procurement of commercially available gages and their evaluation to assess the reliability of manufacturer-supplied calibration factors. Calibration test results for gages embedded in $15.2-\mathrm{cm}-\mathrm{diam}$ by $54-\mathrm{cm}$ cylindrical concrete specimens indicated that calibration factors should be determined (verified) by embedding samples of the gages in test specimens fabricated using a representative mix and that further research should be conducted on other measurement techniques based on inductance, capacitance, semiconductors, and fluidic principles. 


\section{INTRODUCTION}

Instrumentation of prestressed concrete pressure vessels (PCPVs) is required to determine strain distributions, deflections, stresses, temperature distributions, cracking magnitudes, forces in prestressing, and free moisture content. These quantities are utilized to assess the safety and reliability of PCPVs for short- and long-term operation, the correctness of calculations and assumptions of analytical techniques, and the complex behavior of the vessels, especially their structural integrity for exiended peiluds of Lime.

Numerous commercial concrete embedment instrumentation systems are available for indicating stresses, stralns, loads, and muisture content. Since instrumentation is so vital in providing a continuing reassurance of the safe operation of PCPVs, it is imperative that the information provided by these devices have a high degree of reliability. To provide insight into performance of these instruments, laboratory investigations are being conducted. These investigations have a twofold objective: to evaluate current commercially available systems and (2) to provide data for modification of existing designs and/or development of new syslellls.

This report, the first of two related to evaluations of commerclally available strain meters for concrete embedment, presents results of calibration tests conducted on selected meters. The approach was divided into two phases: (1) an overview of strain meters for concrete embedment and (2) an experimental evaluation to assess the reliability of manufacturersupplied calibration factors.

\section{STRAIN METERS FOR CONCRETE EMBEDMENT}

\section{Performance Characteristics for PCPV Applicaliuns}

The measurement of strain (or stress) in concrete structures is much more complex than it might appear. Concrete is a heterogeneous material composed of a hydrated portland cement paste matr1x which may contain unhydrated.cement particles, voids, water, and fine and coarse aggregate particles. Behavior of the concrete system is a function of the relative quantities of its constituents and their response to loading and 
environmental influences. Characteristics of concrete include a nonlinear stress-strain response, time-dependent deformation such as changing values of elastic modulus and strength properties, and differences in tensile and compressive behavior. To further complicate strain and stress measurements in concrete, the loadings are often biaxial or triaxial; measurement of one quantity can influence the results of another quantity; and the instrumentation system, which must be embedded in the concrete can disturb the continuity of the material if the instrument is not properly matched to the concrete properties. Instruments designed for PCPV applications must be able to operate in the alkallne-humid environment of concrete and also to survive elevated temperatures and low-level radiation for the design life of the PCPV, which is often 20 to 30 years.

Strain meters for embedment in concrete structures should incorporate as many as possible of the following desirable gage characteristics:

1. The gage length should be a minimum of eight to ten times the maximum aggregate size to provide an accuracy within $\pm 2.5 \%$ (Ref. 1) for average strains along the gage length.

2. The shape, size, and stiffness of the gage should be such that the gage minimizes the disturbance of the concrete it replaces.

3. The bond between gage and concrete should be such that slip is prevented and overall change in length along the gage length is the same for gage and concrete.

4. The gage should have long-term stability (one year or more) with maximum random drift of possibly $10 \mu \varepsilon$ at $66^{\circ} \mathrm{C}$ and $20 \mu \varepsilon$ at $150^{\circ} \mathrm{C}$ where measurement errors introduced are 1 to $3 \%$. Larger drift with time and temperature is acceptable if systematic and correctable. ${ }^{2}$

5. The gage should have a sensitivity of approximately $1 \mu \varepsilon$ with accuracy of $3 \mu \varepsilon$ and a repcatability of $6 \mu \varepsilon$ (Ref. 2).

6. The gage should have a range of $6000 \mu \varepsilon$ in compression to $2000 \mu \varepsilon$ tension. 2

7. Gage materials should be watertight and resistant to corrosion and should not creep with time.

*Where impractical due to space restrictions, a gage length four times the maximum aggregate size will provide an accuracy within $\pm 5 \%$. 
8. The gage should be easily installed and sufficiently rugged to withstand construction factors.

9. Linear gage response is desirable.

10. Gages within the same manufacturing batch should provide the same results.

11. The coefficient of thermal expansion of the gage should match that of the concrete within which it is to be embedded or the temperature sensitivity of gage should be defined so that corrections may be easily made.

12. The gages should be capable of prolonged operation at $66^{\circ} \mathrm{C}$ and a minimum of one week operation at $90^{\circ} \mathrm{C}$.

13. The gages should be capable of surviving low-level radiation.

14. The gages shall incorporate temperature measurement capability. with an accuracy of $\pm 1^{\circ} \mathrm{C}$.

15. The gages must have dynamic capability.

16. Gage costs and power requircments should not be excessive.

17. The gages should be amenable to remote monitoring and automated data acquisition systems.

In reality, all the above criteria cannot be met; the meters are generally designed to incorporate as many of the above desirable characteristics as possible.

\section{Design Considerations}

As noted above, a device for embedment in concrete to measure strains should precisely match the concrete's elastic and viscoelastic properties, coefficients of thermal expansion, and volume stability of the material it replaces. Since concrete properties are viscoelastic and time dependent, complete matching of the embedded meter and the concrete material it replaces presents an insurmountable task. As a result, the various meters are designed so that errors introduced by the physical property mismatch are as small as possible; that is, for strain measurements the deformation of the strain meter and the displaced concrete are as nearly equal as possible or have a constant ratio to each other. 
Hast, ${ }^{3}$ of Sweden, was one of the first to investigate the effect of gages (inclusions) embedded in concrete such as shown in Fig. 1 . In the figure, the inclusion is presented as a solid cylinder of radius $R$ and length $L$ with an equivalent modulus of elasticity $E_{m}$ embedded in concrete with a modulus $E_{C}$. Load was transmitted from the concrete normal to the plane rigid end surfaces of the meter. Assuming linear elasticity, Hooke's Law yields the following relationships:

$$
\varepsilon_{c} \equiv \sigma / E_{c} ; \varepsilon_{m}=p / E_{m}
$$

However, indicated strains, $\varepsilon_{m}$, were not equal to actual strains, $\varepsilon_{c}$, due to physical property mismatch. Hast derived equations based upon the work of Boussinesq ${ }^{4}$ in the field of stress concentrations, relating stresses in an embedded gage and the surrounding concrete to the modular ratio of the meter to concrete $\left(E_{m} / E_{c}\right)$, meter slenderness ratio $\left(L / r^{\prime}\right)$, and concrete Poisson's ratio $(v)$. Loh ${ }^{5}$ modified Hast's approximate relationship to produce the following relation for calculating the theoretical error in strain indicated by long, slender, cylindrical meters embedded in an infinitel.y l.arge homogenenus, linear elastic body where $L>\pi\left(1-v^{2}\right) R$ :*

$$
\text { Error }=\frac{\varepsilon_{m}-\varepsilon_{c}}{\varepsilon_{c}}=\frac{\left(1-\frac{E_{m}}{E_{c}}\right) \frac{\pi R}{L} \frac{1-v^{2}}{2-\frac{R}{L}\left(1-v^{2}\right)}}{1+\frac{\pi R \cdot E_{m}}{L} \frac{1-v^{2}}{E_{c}} \frac{\pi \Gamma}{L}\left(1-v^{2}\right)} \text {. }
$$

Equation (2) is presented graphically in Fig. 2 for a concrete with a typical Poisson's ratio (0.2) and for modular ratios $\left(E_{m} / E_{c}\right)$ and slenderness ratios $(L / R)$ representative of most commercially available strain meters.

*Reference 5 also presents a similar expression for meters with $L<\pi\left(1-v^{2}\right) R$. 
Error introduced by dissimilar moduli

Most solutions to the problem of an inclusion embedded in a solid body such as presented in Fig. 1 utilize linear elastic solutions such as was done by Hast. Loh's modification to Hast's approximate relationship, Eq. (2), indicates the effects of a modular ratio $\left(E_{m} / E_{c}\right)$ other than 1. As noted from the equation or Fig. 2, the error in indicated strain is negative whenever the ratio is greater than 1 and positive when less than 1. Optimum design of a meter would minimize differences in the modular ratio, which, due to the nonlinearity and time dependence of the concrete stress-strain curve, changes with time. Figure 2 indicates that this occurs when $E_{m} / E_{c}$ is low; however, as noted, errors of $4 \%$ or greater may still be obtained depending on the $L / R$ ratio.

\section{Error resulting from meter geometry}

Equation (2) and Fig. 2 present the effect of the $L / R$ ratio on indicated strain error. The figure shows that to minimize the strain error, the $L / R$ ratio should be as high as possible when the modular ratio. $\left(E_{m} / E_{C}\right)$ is other than 1 .

A related study by Cooke and Seddon ${ }^{1}$ was conducted to determine the effect of the ratio of meter-gage length to maximum aggregate size on errors in indicated strain. Well-graded concretes with maximum aggregate sizes from 0.95 to $0.13 \mathrm{~cm}$ were used for specimen fabrication. Bonded wire resistance strain gages with gage lengths of 2.5 and $1.27 \mathrm{~cm}$ were used for measuring strains, and a $7.62-\mathrm{cm}$ optical extensometer was used as the standard for strain values. Results indicate that to keep strain errors less than $5 \%$, the gage length to maximum aggregate size ratio should be at least 4 . To reduce errors to less than $2.5 \%$, the ratio should be 8 to 10 .

Errors resulting from coefficient of thermal expansion mismatch

Wherever possible, a meter for embedment in concrete is designed so that its coefficient of thermal expansion and that of concrete are as nearly identical as possible. Generally, it is unlikely that the coefficient of thermal expansion for the concrete is known prior to placement. 
Since concrete coefficients can range from as $10 \mathrm{w}$ as $6.7 \mu \mathrm{m} / \mathrm{m} /{ }^{\circ} \mathrm{C}$ to as high as $10.8 \mu \mathrm{m} / \mathrm{m} /{ }^{\circ} \mathrm{C}$, close matching of coefficients of the meter and concrete is difficult and significant errors in strain can occur as temperature changes. Thermal strains generally are considered as a linear function of temperature over the temperature range of interest; therefore, If the average coefficients for both the meter and the concrete and the temperature at the meter location are known, corrections can be easily made. However, it is generally desirable that the meter and concrete coefficients be reasonably close to reduce thermal incompatibility.

Errors resulting from mismatch of Poisson's ratio

Differences in Poisson's ratto between the meter and the concrete matrix within which it is embedded influences the state of stress and deformations in the region of the meter. . Loh ${ }^{5}$ derived equations for stress measurement errors and concluded that errors resulting from Poisson's ratio mismatch were insignificant. Simflarly, the influence of Poisson's ratio mismatch does not significantly influence the strain response of the meter (low transverse sensitivity).

Review of Measurement Techniques for Concrete Embedment Strain Meters

Strain measurements provide data to assess the distribution of stress, creep, and shrinkage of concrete and their effect on prestressing and penetrations and data for design refinement. Problems of strain measurements in PCPVs arise from the concrete environment and reactor operation which involves highly alkaline and humid conditions coupled with elevated temperatures and relatively low radiation levels.

Essentially six basic methods have been utilized for measurement of strains in concrete: (1) electrical resistance, (2) vibrating wire, (3) electrical inductance, (4) electrical capacitance, (5) fluidic principles, and (6) mechanical methods. An overview of these methods is presented in the following sections, and information on several of the more commonly available gages for concrete embedment is presented in Table 1 . For more detalled Informatlon ori the above methods, see Ref. 6 . 
Table 1. Ccncrete embedment strain gages

\begin{tabular}{|c|c|c|c|c|c|c|c|c|c|}
\hline Type & $\begin{array}{l}\text { Gage } \\
\text { length } \\
(\mathrm{cm})\end{array}$ & & $\begin{array}{l}\text { Strein } \\
\text { range } \\
(\mu m, m)\end{array}$ & $\begin{array}{l}\text { Temperature } \\
\text { range } \\
\left({ }^{\circ} \mathrm{C}\right)\end{array}$ & $\begin{array}{l}\text { Sensitivity } \\
(\mu \mathrm{m} / \mathrm{m})\end{array}$ & $\begin{array}{l}\text { Calibration } \\
\text { factor }\end{array}$ & $\begin{array}{l}\text { Feadout } \\
\text { requirements }\end{array}$ & $\begin{array}{l}\text { Approsimate } \\
\text { cost'gage } \\
\text { (0.S. S) }\end{array}$ & Comments \\
\hline \multicolumn{10}{|l|}{ Electrical resistance } \\
\hline $\begin{array}{l}\text { Plastic encapsulated } \\
\text { Type A }\end{array}$ & $1-13$ & $-20,000$ & $00 \mathrm{tcc}+15,00 \mathrm{c}$ & -20 to +80 & 10 & 2.11 & Strain indicato= & $s-23$ & $\begin{array}{l}\text { Stability in moist envircn- } \\
\text { ment quest } 1 \text { mable, volume } \\
\text { change of plastic }\end{array}$ \\
\hline $\begin{array}{l}\text { Plastic encapsulated } \\
\text { Type B }\end{array}$ & 25 & 50,000 & & -100 to $\div 121$ & $5-10$ & 2 & Strain Indicator & 30 & $\begin{array}{l}\text { Good resistance to grease and } \\
\text { ac1ds; sability in moist } \\
\text { environment questionable }\end{array}$ \\
\hline Single wire & $5-15$ & $\pm 20,000$ & & -200 to $>315$ & $5-10$ & 2 & Straia indicator & $5-150$ & $\begin{array}{l}\text { High-temperature use, small } \\
\text { cross section requires } \\
\text { careful placement }\end{array}$ \\
\hline $\begin{array}{l}\text { Unbonded wire Type A } \\
\text { Unbonded wire Type B } \\
\text { Unbonded wire Type C }\end{array}$ & $\begin{array}{l}10-15 \\
10-25 \\
5-10\end{array}$ & $\begin{array}{l}3900 \\
+500 \mathrm{tc} \\
\pm 5000\end{array}$ & $-\vdots 000$ & $\begin{array}{l}65 \\
-30 \text { to }+70 \\
-20 \text { to }+100\end{array}$ & $\begin{array}{l} \pm 5 \\
\pm 6 \\
5-12\end{array}$ & 22.5 & $\begin{array}{l}\text { Bridge circuit } \\
\text { Bridge c1rcuit } \\
\text { Strain indicator }\end{array}$ & $\begin{array}{l}35-75 \\
35-40 \\
50-70\end{array}$ & $\begin{array}{l}\text { Proven reliatility } \\
\text { Proven reliatility } \\
\text { Temperature compensated }\end{array}$ \\
\hline Semiconductor ${ }^{a}$ & $0.16-1.3$ & +3000 & to $-10,000$ & -16 to +800 & & $50-250$ & Bridg circult & $18-25$ & $\begin{array}{l}\text { Very limited concrete appli- } \\
\text { cations, stable, high- } \\
\text { temperature use, sensitive }\end{array}$ \\
\hline \multicolumn{10}{|l|}{ Vibrating wire } \\
\hline VwSG Type A & $7-14$ & $>1000$ & & 80 & 0.5 & $0.96 \times 10^{-3}$ & $\begin{array}{l}\text { Pertod or } \\
\text { frequency meter }\end{array}$ & $3 \leq-75$ & $\begin{array}{l}\text { Used extensively, additional } \\
\text { sealing recommended }\end{array}$ \\
\hline VWSG Iype B & 14 & $>1000$ & & 80 & 0.5 & $3.00 \times 10^{-3}$ & $\begin{array}{l}\text { Perlod or } \\
\text { frequency meter }\end{array}$ & 75 & $\begin{array}{l}\text { Used extensively, additional } \\
\text { sealing recommended }\end{array}$ \\
\hline VWSG Type C & 12.7 & 4000 & & -40 to +66 & 1.0 & $b$ & $\begin{array}{l}\text { Periof or } \\
\text { frequency meter }\end{array}$ & 150 & $\begin{array}{l}\text { Wire tension easily adjusted } \\
\text { temperature measurement } \\
\text { capability }\end{array}$ \\
\hline VWSG Type D & 13 & 3000 & & & 0.5 & $2.60 \times 10^{-3}$ & $\begin{array}{l}\text { Period or } \\
\text { frequency meter }\end{array}$ & 160 & $\begin{array}{l}\text { Temperature, measurement } \\
\text { capability, stability poor } \\
\text { in moist envirorment }\end{array}$ \\
\hline VWSG Type E & 10 & 3000 & & -40 to +80 & 0.1 & $2.01 \times 10^{-3}$ & $\begin{array}{l}\text { Period or } \\
\text { frequency meter }\end{array}$ & Lsa & $\begin{array}{l}\text { Temperature measurement } \\
\text { capabflity }\end{array}$ \\
\hline VWSG Type F & $3 . \varepsilon$ & 1000 & & -10 to +70 & 1 & $1.20 \times 10^{-3}$ & $\begin{array}{l}\text { Perlod or } \\
\text { frequency meter }\end{array}$ & 125 & $\begin{array}{l}\text { Temperature measurement } \\
\text { capabilitiy }\end{array}$ \\
\hline WWSG Type G & 13.3 & 2000 & & -10 to $+70^{c}$ & 1 & $3.00 \times 10^{-3}$ & $\begin{array}{l}\text { Period or } \\
\text { frequency meter }\end{array}$ & $125-200$ & $\begin{array}{l}\text { Temperature measurement } \\
\text { capablifty }\end{array}$ \\
\hline \multicolumn{10}{|l|}{ Inductance } \\
\hline WES $\operatorname{gage}^{a}$ & 10.2 & 30,000 & & & \pm 10 & & Carrier amplifier & $200-300$ & $\begin{array}{l}\text { Stable, low gage modulus } \\
\text { limited number of gages } \\
\text { fabricated }\end{array}$ \\
\hline
\end{tabular}

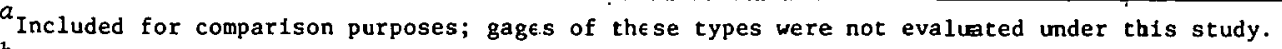

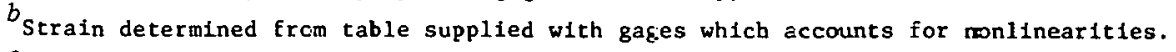

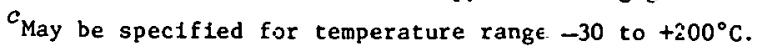


Electrical resistance methods

Strains are indicated by length changes of a small-diameter elastic wire or thin foil. The length changes are sensed as changes in resistance in an electrical circuit. Devices which ut1lize this principle include bonded encapsulated or enclosed metal resistance meters, unbonded metal resistance meters, and semiconductor meters.

Bonded encapsulated or enclosed strain meters are based on the same wire resistance-deformation principle as the unbonded meters. The two basic gage types are (I) a standard electrical resistance strain gage such as an SR-4 or foil gage encapsulated in a plastic material or enclosed in a metal envelope and (2) a strain-sensitive wire filament insulated by a highly compacted magnesium oxide powder and enclosed in a. small-diameter stainless steel tube. Standard strain gage signal conditioning equipment is used to convert the small deformations (resistance changes) to strains. Advantages and limitations for each type of gage are listed below.

Plastic encapsulated

Advantages

- low cost

- wide range

- ease of placement

Limitations

- limited ability of the encapsulant to provide a good moisture barrier

- volume changes of the encapsulant due to water absorption and high thermal expansion

- self-heating effects produced by low thermal conductivity of plastic encapsulant

- strain gradients caused by a relatively thick encapsulant

- creep of the encapsulant 


\section{Metal encapsulated}

\section{Advantages}

- high length-to-equivalent diameter ratio

- good moisture resistance

\section{Limitations}

- high coefficient of thermal expansion

- difficulty in achieving proper embedment and alignment

- fragility of the meter

- possible deterioration of bond between meter and concrete under cyclic loading

Wire filament

Advantages

- high length-to-diameter ratio

- wide strain range

- use to temperatures greater than $300^{\circ} \mathrm{C}$

\section{Limitations}

- difficulty in determining the gage factor

- apparent strain differences during temperature cycles

Examples of bonded encapsulated or enclosed strain meters include the Japanese polyester mold gage, the BLH encapsulated gage, the Valore gage, and the Ailtech integral lead gage.

To protect the gaging system, the unbonded electrical resistance. meters consist of a casing which contains either a small-diameter elastic wire or a thin metal strip to which are attached conventional strain gages. Length changes due to small casing deformations are sensed as changes in resistance. These small changes in resistance are measured by using a Wheatstone bridge for the elastic wire and a conventional. strain gage signal conditioning circuit for the thin metal strip. Advantages and limitations of the gages are listed below.

\section{Advantages}

- relatively low cost

- ease of readout by simple electronic equipment or automated data logging system 
- ease of placement

- availability of a large number of gage lengths

- built-in temperature compensation in some cases

- temperature measurement capability

Limitations

- sensitivity to changes in electrical resistance of leads and contact points

- limited temperature and strain ranges

- sensitivity to temperature changes in some cases

- requirement of an air-pressure line for some gages

Unbonded metal resistance meters include the Carlson strain meter, Kyowa strain meter, Texas Measurements strain meter, and the Monfore standardizing strain gage.

Applications of semiconductor strain gages for measurement of strains in concrete àre very limited. They offer advantages and limitations as listed.

\section{Advantages}

- high strain sensitivity

- good stability

- increased tolerance to leakage

- meter miniaturization

\section{Limitations}

- poor linearity (especially at elevated temperatures)

- relatively high cost

- requirement of expensive and sophisticated readout circuits

Vibrating wire methods

Acoustic methods relate resonant frequency measurement to deformation changes. The most common type of acoustic gage is the vibratingwire strain meter, which consists of a tensioned steel wire housed within a cylindrical tube and clamped between two end flanges. Also contained in the gage adjacent to the wire is an electromagnetic plucking coil. A pulse of current supplied to the coil causes the wire to oscillate, thus 
inducing an alternating current in the plucking coil which varies at the same frequency as the wire. Strains are obtained from the natural frequency reading of the wire, which is proportional to the square of the distance between the end flanges. Temperature measurement capability is also genera1ly incorporated into the gages so that the readings may be corrected for temperature effects. Advantages and limitations are included below.

\section{Advantages}

- long-term stability and reliability

- high accuracy

- strains not affected by lead length

- readings taken by portable period (or frequency) or automatic data logging systems

\section{Limitations}

- limited strain and temperature range

- careful sealing of meter required to prevent ingress of water

- results influenced by vibrations in vicinlty of gage

- relativcly crponeive

- size is too large for small model tests

- temperature compensation required

Numerous vibrating-wire strain meters are commercially available for concrete embedment.

Electrical inductance methods

Electrical inductance meters use electromagnetic and electrostacte fields as displacement sensors; that is, mechanical movement varies the reluctance of a magnetic circuit. Listed below are the advantages and limitations associated with these gages.

\section{Advantages}

- long-term stability

- parts unstressed so creep is negligible

- wide strain range

- high output with good resolution

- low stiffness which permits monitoring of concrete strains at early concrete ages 


\section{Limitations}

- relatively high cost

- difficulty in making temperature corrections

- possible temperature dependence of the ferromagnetic properties Applications of inductance meters to concrete strain determinations are quite limited. One of the few known inductance meters for concrete embedment has been recently developed in Vicksburg, Mississippi. ${ }^{7}$

\section{Electrical capacitance methods}

Electrical capacitance strain meters relate changes in capacitance, as sensed by changes of separation or area between elements, to displacements. Advantages and limitations are listed below.

Advantages

- operation under adverse environments

- high sensitivity and output

- linearity

- wide strain range

- rapid data acquisition permitted by automatic self-balancing bridges Limitations

- relatively expensive

- questionable long-term stability

- problems presented by long cable lengths and temperature compensation

Only one documented application of electrical capacitance for a concrete embedment gage has been identified; ${ }^{8}$ however, this was over 20 years ago and temperature compensation, long-term stability, and measurement circuits presented major problems.

Fluidir: methods

Fluidic metering methods for strain measurements utilize a liquid or gaseous fluid as the signal medium and pressures and flows as the signal quantities. In a typical application a fluid passes through a nozzle to a closely adjusted plate and then returns to the supply. If the distance 
between the nozzle and deflecting plate changes; the resistance (pressure) to flow changes. Circuiting of the meters is analogous to a wheatstone bridge circuit for wire resistance strain gages. Associated advantages and limitations are included below.

\section{Advantages}

- good accuracy and sensitivity

- heat and radiation resistance

- capability for self-temperature compensation

- ease of operation

\section{Limitations}

- unproven long-term stability

- requirement of highly skilled craftsmen for fabrication

- additional transducing devices (electrical) required for automatic data acquistion systems

Fluidic meters for concrete embedment such as an air-operated needlenozzle system ${ }^{9}$ are presently being developed in Europe for PCPV application.

Mechanical methods

Conventional mechanical and optical-mechanical merhods such as the Huggenberger gage, Tuckerman optical extensometer, or the Whittemore gage are not suitable for internal concrete strain measurements. However, one such system under development in Germany, the Bowden-w1re system, 10 may have potential PCPV applications. One such device consists of a 2.5-mm-diam thick-walled annealed stainless steel tube containing a single hardened steel wire coupled to a transducer which converts the mechanical displacements into electrical signals. Advantages and limitations are included below.

\section{Advantages}

- displacements and 1ntegrated strains may be transmitted along arbitrary curves on the surface as well as inside concrete

- relatively independent of radiation effects 
Limitations

- low sensitivity

- temperature-induced errors if coefficients of expansion of wire, tube, and concrete are not matched

As with the fluidic method, mechanical concrete embedment gages are in the developmental stage.

\section{EVALUATION OF STRAIN METERS FOR CONCRETE EMBEDMENT}

Numerous commercial strain meters are available for measurement of strains in concrete. To demonstrate the continuing safety of PCPVs, it is imperative that the values obtained from these meters be extremely re1iable. Rather than accept manufacturer's performance claims without question, it is desirable that the accuracy of these meters be evaluated experimentally. To establish performance reliability trends for available strain meters, a representative sample of strain meter types was obtained for evaluation.* These meters are noted in Table.I along with manufacturer-supplied general gage characteristics such as gage length, strain range, sensitivity, calibration factor, readout requirements, and cost factors. Accuracy of the meters, identified by the reliability of the manufacturer's calibration factor, was established by means of calibration tests. Related studies were also conducted to establish a calibration test specimen geometry and to identify, if posstble, the influence of maximum size aggregate and modular ratio.

\section{Calibration Test Specimen Geometry}

Prior to conduction of the main calibration test series, a limited laboratory study was conducted to select a test specimen geometry. Three sets of specimens were cast using the same mix design (gravel/cement ratio $=2.64$, sand/cement ratio $=2.04)$ except for water/cement ratio $(0.42$,

*The large number of different types and brands of strain meters available necessitated that the study restrict itself to meters readily obtainable in the United States. 
$0.50,0.58)$, which was varied to produce different strength concretes.* Each specimen set consisted of cylinders having diameters of $0.05,0.08$, 0.10 ; and $0.15 \mathrm{~m}$ and constant length-to-diameter ratios of 3.54. Embedded in each specimen was an unbonded wire Type A gage aligned with the specimen axis. After curing in a laboratory environment for approximately six months, two $0.1-\mathrm{m}$ surface strain gages were applied to each concrete specimen at $180^{\circ}$ intervals and connected in series to compensate for specimen bending if it should occur. The specimens were loaded in uniaxial compression to failure with surface and embedded strain gage readings obtained at specified intervals.

Figure 3 presents stress-strain plots obtained from the surface strain gages and embedded gages. It can be noted from the figure that the strains from surface gages were always less than strains from the embedded gages at the same stress level. No significant difference between embedded and surface strain gage results was noted when strength effects were compared between data sets; however, the difference between low and high strengths for the test series ( 31.9 vs $41.2 \mathrm{MPa}$ ) was probably not significant enough to show a data trend. This effect will be investigated later. The important thing to note is that as the specimen diameter increased there was a trend toward better agreement between surface and embedded gage results. This is more obvious in Table 2, which presents a summary of test results for the callbration specimen size test series. Figures 4 to 6 are plots of ratio difference vs surface strain for mixes 5,6 , and 7, respectively. A comparison of differences between manufacturer-supplied and actual calibration factors obtained from the slopes of "best-fit" straight lines of surface gage strain vs embedded gage ratio difference shows that the $0.05-$ and the $0.15-\mathrm{m}$-diam cylinders averaged 39.5 and $14.5 \%$, respectively. Based on these results, a $0.15-\mathrm{m}-$ diam by $0.54-m-10 n g$ test specimen was selected for the calibration test series.

*Properties of the mixes for the water/cement ratios of $0.42,0.50$, and 0.58 are presented in Table 4 as mixes 5, 6, and 7 , respectively. 
Table 2. Calibration specimen size test series (unbonded wire Type A gages)

\begin{tabular}{lcccccc}
\hline $\begin{array}{l}\text { Mix } \\
\text { No. }\end{array}$ & $\begin{array}{c}\text { Cylinder } \\
\text { diameter } \\
(\mathrm{cm})\end{array}$ & $\begin{array}{c}\text { Calibration } \\
\text { factor } \\
\text { supplied }\end{array}$ & $\begin{array}{c}\text { Cylinder } \\
\text { failure } \\
\text { stress } \\
(\mathrm{MPa})\end{array}$ & $\begin{array}{c}\text { Elastic } \\
\text { modulus } \\
\text { (GPa) }\end{array}$ & $\begin{array}{c}\text { Calculated } \\
\text { calibration } \\
\text { factor }\end{array}$ & $\begin{array}{c}\text { Calibration } \\
\text { factor } \\
\text { difference } \\
(\%)\end{array}$ \\
\hline 5 & 5.1 & 532 & 26.4 & 26.7 & 294 & +44.7 \\
5 & 7.6 & 537 & 21.7 & 27.1 & 274 & +49.0 \\
5 & 10.2 & 530 & 29.2 & 33.9 & 407 & +23.2 \\
5 & 15.2 & 532 & 41.2 & 30.8 & 492 & +7.5 \\
6 & 5.1 & 538 & 21.8 & 20.1 & 407 & +24.3 \\
6 & 7.6 & 529 & 24.1 & 30.9 & 238 & +55.1 \\
6 & 10.2 & 533 & 29.4 & 31.6 & 374 & +29.9 \\
6 & 15.2 & 538 & 34.4 & 29.9 & 443 & +17.7 \\
7 & 5.1 & 534 & 19.6 & 18.4 & 269 & +49.6 \\
7 & 7.6 & $c$ & 24.3 & 25.2 & $c$ & + \\
7 & 10.2 & 529 & 26.5 & 23.9 & 444 & +16.0 \\
7 & 15.2 & 531 & 31.9 & 30.8 & 434 & +18.2 \\
\hline
\end{tabular}

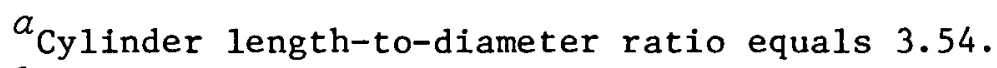

$b_{\text {Percent difference }}=$ [ (gage factor supplied - gage factor calculated)/gage factor supplied] $\times 100 \%$.

$c_{\text {Bad embedment gage. }}$

\section{Cal1bration Tests of Concrete Embedment Strain Meters}

Calibration factors were determined for the strain meters noted in Table 1. Type II portland cement was used throughout the investigation. Crushed limestone coarse and fine aggregates used were obtained from a local supplier. Aggregate gradations for the various mixes are presented in Table 3, and mix designs and plastic and hardened concrete properties are presented in Table 4.

The $0.15-\mathrm{m}$-diam by $0.54-\mathrm{m}-1$ ong calibration test specimens were cast in molds fabricated from standard polyvinyl chloride water pipe which had been cut to length and the ends milled so that they were plane. Contained within each specimen was an embedment strain meter aligned with the cylinder axis. Alignment of the gage was maintained by small-diameter wires extending radially from the gage. The molds were meticulously filled with concrete, and the gage was protected so that concrete was not permitted 
Table 3. Aggregate gradations

(cumulative weight percent retained)

\begin{tabular}{|c|c|c|c|c|c|c|c|c|}
\hline \multirow{2}{*}{$\begin{array}{c}\text { Sieve } \\
\text { designation }\end{array}$} & \multirow{2}{*}{$\begin{array}{c}\text { Fine } \\
\text { aggregate }\end{array}$} & \multicolumn{3}{|c|}{ Coarse aggregate } & \multicolumn{4}{|c|}{ Combined fine and coarse aggregate } \\
\hline & & No. 1 & No. 2 & No. 3 & $\begin{array}{l}\text { Series A } \\
\text { mixes }^{a}\end{array}$ & $\begin{array}{l}\text { Series }_{b} B \\
\text { mixes }\end{array}$ & $\begin{array}{l}\text { Series } C \\
\text { mixes }\end{array}$ & $\underset{\text { mixes }}{\operatorname{Series}} d$ \\
\hline \multicolumn{9}{|l|}{$3.81 \mathrm{~cm}$} \\
\hline $1.91 \mathrm{~cm}$ & & & 1.05 & 95.11 & 1.44 & 2.07 & & 23.93 \\
\hline $0.95 \mathrm{~cm}$ & & & 46.11 & 99.90 & 29.54 & 42.34 & & 31.63 \\
\hline No. $C$ & 0.22 & 97.53 & 92.71 & 100.00 & 39.12 & 55.98 & 38.59 & 38.51 \\
\hline No. 8 & 7.95 & 100.00 & 100.00 & 100.00 & 44.17 & 59.88 & 44.25 & 44.25 \\
\hline No. 16 & 43.64 & 100.00 & 100.00 & 100.00 & 65.82 & $75.44^{\prime}$ & 65.86 & 65.87 \\
\hline No. 30 & 64.26 & 100.00 & 100.00 & 100.00 & 78.32 & 84.43 & 78.35 & 78.35 \\
\hline No. 50 & 78.00 & 100.00 & 100.00 & 100.00 & 86.65 & 90.42 & 86.67 & 86.68 \\
\hline No. 100 & 89.59 & 100.00 & 100.00 & 100.00 & 93.68 & 95.47 & 93.69 & 93.75 \\
\hline No. 200 & 95.64 & 100.00 & 100.00 & 100.00 & 97.35 & 98.11. & 97.36 & 97.41 \\
\hline Minus No. 200 & 100.00 & 100.00 & 100.00 & 100.00 & 100.00 & 100.00 & 100.00 & 100.00 \\
\hline Fineness modulus & 2.84 & 5.98 & 7.40 & 7.95 & 4.39 & 5.06 & 4.07 & 4.63 \\
\hline
\end{tabular}

$G_{\text {Series }} \mathrm{A}$ mixes included mixes $1,2,3,4$, and 14 of Table 4.

$b_{\text {Series } B}$ mixes included mixes $5-8$ anc $15-21$ of Table 4.

${ }^{c}$ Series $\mathrm{C}$ mixes included $\mathrm{mix} 12$ of Tat.le 4 .

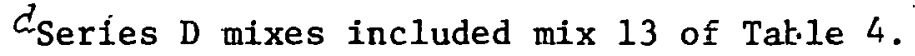


Table 4. Properties of concrete mixes

\begin{tabular}{|c|c|c|c|c|c|c|c|c|c|c|}
\hline \multirow{3}{*}{$\begin{array}{l}\text { Mix. } \\
\text { No. }\end{array}$} & \multirow{2}{*}{\multicolumn{4}{|c|}{ Relative weight, SSD basis }} & \multicolumn{3}{|c|}{ Plastic concrete properties } & \multicolumn{3}{|c|}{ Hardened concrete properties } \\
\hline & & & & & \multirow{2}{*}{$\begin{array}{l}\text { Unit } \\
\text { "weight } \\
\left(\mathrm{kg} / \mathrm{m}^{3}\right)\end{array}$} & \multirow[b]{2}{*}{$\begin{array}{l}\text { Slump } \\
(\mathrm{cm})\end{array}$} & \multirow{2}{*}{$\begin{array}{l}\text { Air } \\
\text { content } \\
(\%)\end{array}$} & \multirow{2}{*}{$\begin{array}{c}\text { Elastic modulus } \\
\text { initial cycle } \\
(\mathrm{GPa})\end{array}$} & \multirow{2}{*}{$\begin{array}{c}\text { Elastic modulus } \\
\text { failure cycle } \\
(\mathrm{GPa})\end{array}$} & \multirow{2}{*}{$\begin{array}{l}\text { Failure } \\
\text { stress } \\
\text { (MPa) }\end{array}$} \\
\hline & Cement & Sand & Gravel & Water & & & & & & \\
\hline 1 & 1.00 & 2.84 & 1.85 & 0.56 & 2410 & 15.2 & 1.8 & 33.1 & 31.4 & 34.0 \\
\hline 2 & 1.00 & 2.84 & 1.85 & 0.56 & 2420 & 10.8 & 2.2 & 26.7 & 22.5 & 24.9 \\
\hline 3. & 1.00 & 2.84 & 1.85 & 0.56 & 2430 & 8.9 & 2.0 & 26.3 & 23.3 & .24 .9 \\
\hline 4 & 1.00 & 2.84 & 1.85 & 0.56 & 2410 & 14.0 & 2.3 & 30.4 & 28.2 & 33.4 \\
\hline 5 & 1.00 & 2.04 & 2.64 & 0.42 & & & & & 31.8 & 41.2 \\
\hline 6 & 1.00 & 2.04 & 2.64 & 0.50 & & & & & 30.6 & 34.4 \\
\hline 7 & 1.00 & 2.04 & 2.64 & 0.58 & & & & & 30.0 & 31.9 \\
\hline 8 & 1.00 & 2.02 & 2.60 & 0.49 & & & & 30.5 & 29.9 & 38.5 \\
\hline 12 & 1.00 & 2.83 & 1.85 & 0.56 & 2350 & 1.9 & 3.8 & 27.9 & 25.9 & 30.0 \\
\hline 13 & 1.00 & 2.83 & 1.85 & 0.56 & 2410 & & 0.8 & 24.6 & 25.8 & 24.9 \\
\hline 14 & 1.00 & 2.85 & 1.86 & 0.56 & 2370 & 3.8 & 3.6 & 30.4 & 28.7 & 31.2 \\
\hline 15 & 1.00 & 2.04 & 2.64 & 0.40 & 2440 & 1.3 & 2.6 & 36.3 & 36.1 & 41.8 \\
\hline 16 & 1.00 & 2.04 & 2.64 & 0.60 & 2370 & $>15.0$ & 1.4 & 23.7 & 22.9 & 20.2 \\
\hline 17 & 1.00 & 2.04 & 2.64 & 0.50 & 2400 & 15.2 & 2.0 & 27.7 & 26.7 & 28.0 \\
\hline 18 & 1.00 & 2.04 & 2.64 & 0.50 & 2380 & 8.3 & 3.0 & 27.7 & 26.4 & 27.0 \\
\hline 19 & 1.00 & 2.04 & 2.64 & 0.50 & 2400 & 10.2 & 2.1 & 28.2 & 27.3 & 31.4 \\
\hline 20 & 1.00 & 2.02 & 2.60 & 0.49 & 2450 & 2.5 & 2.2 & 30.3 & 31.1 & 38.3 \\
\hline 21 & 1.00 & 2.00 & 2.57 & 0.48 & 2420 & 2.5 & 2.3 & 30.4 & 31.0 & 30.9 \\
\hline
\end{tabular}


to fall directly on the gage and alter its alignment. Compaction of the concrete was done externally with a vibrating table. Approximately $4 \mathrm{hr}$ after casting, the cylinders were capped with a neat cement paste (water/ cement ratio $=0.30$ ) which had been mixed $1 \mathrm{hr}$, allowed to set $1 \mathrm{hr}$, and remixed 3 min prior to use. After the concrete was cured ( $>28$ days), three sets of mechanical gage points with $0.20-\mathrm{m}$ gage lengths were placed at $120^{\circ}$ intervals around the circumference of each specimen, and two $0.1-$ $m$ electrical resistance strain gages were placed at $180^{\circ}$ intervals on the circumference of the cylinder and connected in series to average bending effects which might occur. Strains obtained from the mechanical gage points and surface strain gages were used as reference values for the embedded gage strains.

At least two calibration specimens were tested for each of the 14 strain meters noted in Table 1 . The test procedure consisted of

1. calibrating load and strain gage response,

2. taking zero readings,

3. loading the specimen in compression to approximately $50 \%$ of its ultimate load in 22.2-kN increments with readings (mechanical, surface, and embedded gages) taken at each load increment,

4. unloading in $22.2-\mathrm{kN}$ increments with readings taken at each increment, 5. rechecking and rezeroing load and strain calibrations,

6. reloading the specimen in compression to specimen failure with surface and embedded gage readings taken at each $22.2-\mathrm{kN}$ increment.

Figure 7 presents the calibration test setup.

Gage calibration factors were determined from surface gage strains for each of the embedded gages tested. Mechanical gage strain values obtained during the initial load cycle were used as a check for surface strain gage results. Calibration factors for the bonded-wire resistance gages and the unbonded-wire Type $C$ gage were calculated by multiplying the manufacturer-supplied calibration factor by the reciprocal of the slope of the "best-fit" straight line through the surface gage strain vs embedded gage strain data. Unbonded-wire calibration factors were calculated by determining the slope of the "best-fit" straight line through the surface gage strain vs gage ratio difference data. Vibrating wire-type 
strain meter calibration factors were calculated by determining the slope of the "best-fit" straight line through the surface gage strain vs the difference in frequency squared of the vibrating wire gage. Test data for the bonded-wire gages are presented in Figs. 8 to 12,13 to 16, and 17 to 27 for the plastic encapsulated Type A, plastic encapsulated Type $B$, and single-wire gages, respectively. Figures 28 to 44,45 to 48 , and 49 to 52 present test data for the unbonded-wire gages Types A, B, and C, respectively. Test data for the vibrating wire gage Types A to $G$ are presented in Figs. 53 to 55, 56 to 57,58 to 62,63 to 64,65 to 66,67 to 71 , and 72 to 83 , respectively. Table 5 presents a summary of results for the calibration test series. Variations in gage factor for a particular gage may be attributable to the concrete mix; that is, since all gages of one type may not have been embedded in concrete from the same mix, there may be different degrees of bleeding at the upper flange of the gage and this has been shown to influence calibration results.ll These results show that differences between manufacturer-supplied and experimentally determined calibration factors were significant enough in all cases that calibration tests should be conducted prior to the use of a particular gage. These tests should be conducted by embedding samples of the gages from the specific batch in test specimens appropriately sized and fabricated from a representative concrete mix.

Effect of maximum aggregate size on embedded strain meter performance

It is generally recommended that the gage length of embedded gages be at least three to five times the size of the largest maximum aggregate size. These conclusions are derived largely from the work of Cooke and Seddon ${ }^{1}$ in which bonded-wire resistance gages with gage lengths of either 1.27 or $2.3 \mathrm{~cm}$ were altached to the surfaces of specimens fabricated from concretes with maximum aggregate sizes ranging from 0.13 to $0.95 \mathrm{~cm}$. To substantiate that this is also true for strain meters embedded in concrete, a limited test series was cunducted.

Specimens with the same geometry as the standard calibration test specimens were used in the study. Either unbonded-wire Type A or VWSG Type $G$ strain meters were cast in concretes having e1ther $0.95,1.91$, or 
Table 5. Summary of test resnlts for $15.2-\mathrm{cm}-\mathrm{diam}$ by $54-\mathrm{cn}$ calfbraticr. țest cylinders

\begin{tabular}{|c|c|c|c|c|c|c|c|c|c|c|c|}
\hline \multirow[b]{2}{*}{ Gage type } & \multirow[b]{2}{*}{$\begin{array}{l}\text { Gage } \\
\text { No. }\end{array}$} & \multirow[b]{2}{*}{$\begin{array}{l}\text { Mix } \\
\text { No. }\end{array}$} & \multirow[b]{2}{*}{$\begin{array}{l}\text { Calibration } \\
\text { factor } \\
\text { supplied }\end{array}$} & \multicolumn{4}{|c|}{ Initial load cycle } & \multicolumn{4}{|c|}{ Failure load cycle } \\
\hline & & & & $\begin{array}{l}\text { Maximun } \\
\text { stress } \\
\text { jevel } \\
\text { (MPy) }\end{array}$ & $\begin{array}{l}\text { Elas:ic } \\
\text { modulus } \\
\quad(\mathrm{GPa})\end{array}$ & $\begin{array}{l}\text { Calcilated } \\
\text { calibration } \\
\text { factor }\end{array}$ & $\begin{array}{c}\text { Calibration } \\
\text { factor } \\
\text { difference } \\
(\%)\end{array}$ & $\begin{array}{l}\text { Cylinder } \\
\text { fai.iure. } \\
\text { stzess } \\
\text { (MPa) }\end{array}$ & $\begin{array}{l}\text { Elastic } \\
\text { modulus } \\
\text { (GPa) }\end{array}$ & $\begin{array}{l}\text { Calculated } \\
\text { calibration } \\
\text { factor }\end{array}$ & $\begin{array}{c}\text { Calibration } \\
\text { factor } \\
\text { difference } \\
(\%)\end{array}$ \\
\hline Electrical resistance & & & & & & . & & & & & \\
\hline Plastic encapsulated Type A & $\begin{array}{l}1 \\
2 \\
3 \\
4 \\
5\end{array}$ & $\begin{array}{r}1 \\
3 \\
3 \\
19 \\
21\end{array}$ & $\begin{array}{l}2.11 \\
2.11 \\
2.11 \\
2.11 \\
2.11\end{array}$ & $\begin{array}{l}14.5 \\
17.1 \\
17.1 \\
14.5 \\
14.5\end{array}$ & $\begin{array}{l}32.1 \\
24.4 \\
28.2 \\
30.6 \\
29.0\end{array}$ & $\begin{array}{l}2.27 \\
1.56 \\
2.18 \\
1.95 \\
2.09\end{array}$ & $\begin{array}{r}-7.6 \\
+26.1 \\
-3.3 \\
+7.6 \\
+1.0\end{array}$ & $\begin{array}{l}33.9 \\
23.4 \\
23.4 \\
32.1 \\
32.8\end{array}$ & $\begin{array}{l}31.7 \\
20.5 \\
23.9 \\
27.9 \\
29.5\end{array}$ & $\begin{array}{l}2.36 \\
1.55 \\
2.14 \\
1.88 \\
2.11\end{array}$ & $\begin{array}{r}-11.8 \\
+26.5 \\
-1.4 \\
+10.9 \\
0\end{array}$ \\
\hline Plastic encapsulated Type B & $\begin{array}{l}1 \\
2 \\
3 \\
4\end{array}$ & $\begin{array}{l}18 \\
19 \\
18 \\
19\end{array}$ & $\begin{array}{l}2.00 \\
2.00 \\
2.00 \\
2.00\end{array}$ & $\begin{array}{l}14.5 \\
14.5 \\
14.5 \\
14.5\end{array}$ & $\begin{array}{l}29.8 \\
26.5 \\
27.5 \\
28.1\end{array}$ & $\begin{array}{l}1.92 \\
1.96 \\
1.79 \\
2.07\end{array}$ & $\begin{array}{r}+4.0 \\
+2.0 \\
+10.5 \\
-3.5\end{array}$ & $\begin{array}{l}2: .3 \\
28.7 \\
2 \vdots .9 \\
31.4\end{array}$ & $\begin{array}{l}28.0 \\
27.4 \\
26.5 \\
28.5\end{array}$ & $\begin{array}{l}1.83 \\
1.84 \\
1.78 \\
2.02\end{array}$ & $\begin{array}{r}+8.5 \\
+8.0 \\
+11.0 \\
-1.0\end{array}$ \\
\hline Single wire & $\begin{array}{r}1 \\
2 \\
3 \\
4 \\
5 \\
6 \\
7 \\
8 \\
9 \\
10 \\
11\end{array}$ & $\begin{array}{c}3 \\
4 \\
4 \\
21 \\
21 \\
16 \\
17 \\
15 \\
15 \\
12^{b} \\
13^{c}\end{array}$ & $\begin{array}{l}2.00 \\
2.00 \\
2.00 \\
2.00 \\
2.00 \\
2.00 \\
2.00 \\
2.00 \\
2.00 \\
2.00 \\
2.00\end{array}$ & $\begin{array}{r}17.2 \\
17.2 \\
17.2 \\
14.6 \\
14.6 \\
7.8 \\
14.6 \\
17.2 \\
17.2 \\
17.1 \\
12.5\end{array}$ & $\begin{array}{l}24.8 \\
30.5 \\
32.3 \\
30.3 \\
31.8 \\
22.2 \\
28.9 \\
35.1 \\
35.1 \\
28.7 \\
20.8\end{array}$ & $\begin{array}{l}1.63 \\
1.65 \\
1.94 \\
1.54 \\
1.98 \\
1.54 \\
1.82 \\
1.38 \\
1.41 \\
1.63 \\
1.31\end{array}$ & $\begin{array}{r}+18.6 \\
+17.5 \\
+3.0 \\
+23.0 \\
+1.0 \\
+23.0 \\
+9.0 \\
+31.0 \\
+29.5 \\
+18.5 \\
+34.5\end{array}$ & $\begin{array}{l}2 C .1 \\
35.6 \\
3 E .1 \\
3 C .6 \\
25.2 \\
2 Z .3 \\
3 C .3 \\
43.3 \\
41.4 \\
29.9 \\
22.4\end{array}$ & $\begin{array}{l}20.2 \\
29.2 \\
31.6 \\
31.9 \\
31.7 \\
21.6 \\
27.4 \\
34.1 \\
35.0 \\
25.0 \\
22.0\end{array}$ & $\begin{array}{l}1.74 \\
1.71 \\
2.02 \\
1.63 \\
2.20 \\
1.51 \\
1.75 \\
1.52 \\
1.50 \\
1.73 \\
1.45\end{array}$ & $\begin{array}{r}+13.0 \\
+14.5 \\
-1.0 \\
+18.5 \\
-10.0 \\
+24.5 \\
+12.5 \\
+24.0 \\
+25.0 \\
+13.5 \\
+27.5\end{array}$ \\
\hline Unbonded wire Jype A & $\begin{array}{r}1 \\
2 \\
3 \\
4 \\
5 \\
6 \\
7 \\
8 \\
9 \\
10 \\
11\end{array}$ & $\begin{array}{r}2 \\
2 \\
4 \\
20 \\
16 \\
16 \\
17 \\
17 \\
15 \\
15 \\
5\end{array}$ & $\begin{array}{l}528 \\
532 \\
536 \\
5 \approx 7 \\
5 \approx 7 \\
5 \approx 9 \\
5 \vdots 6 \\
5 \vdots 6 \\
541 \\
5 \vdots 5 \\
5 \vdots 2\end{array}$ & $\begin{array}{r}17.1 \\
17.1 \\
1 \% .1 \\
14 . \epsilon \\
1.11 \\
9 . \varepsilon \\
14.6 \\
1 . .6 \\
1: .1 \\
1: .1\end{array}$ & $\begin{array}{l}25.8 \\
26.3 \\
29.7 \\
24.9 \\
23.4 \\
24.4 \\
28.8 \\
28.8 \\
34.4 \\
36.2\end{array}$ & $\begin{array}{l}422 \\
451 \\
449 \\
526 \\
444 \\
487 \\
433 \\
468 \\
503 \\
520\end{array}$ & $\begin{array}{r}\div 20.1 \\
+15.2 \\
+16.2 \\
0 \\
+15.7 \\
+7.9 \\
+19.2 \\
+12.7 \\
+7.0 \\
+2.8\end{array}$ & $\begin{array}{l}24.9 \\
25.0 \\
33.0 \\
38.0 \\
24.1 \\
19.1 \\
27.0 \\
30.3 \\
41.4 \\
41.0 \\
41.2\end{array}$ & $\begin{array}{l}20.8 \\
21.8 \\
26.3 \\
27.0 \\
21.1 \\
25.5 \\
26.7 \\
27.5 \\
35.8 \\
35.5 \\
31.8\end{array}$ & $\begin{array}{l}429 \\
469 \\
433 \\
520 \\
440 \\
474 \\
431 \\
463 \\
515 \\
519 \\
492\end{array}$ & $\begin{array}{r}+18.8 \\
+11.8 \\
+19.2 \\
+1.3 \\
+16.5 \\
+10.4 \\
+19.6 \\
+13.6 \\
+4.8 \\
+3.0 \\
+7.5\end{array}$ \\
\hline & $\begin{array}{l}12 \\
13\end{array}$ & $\begin{array}{l}6 \\
7\end{array}$ & $\begin{array}{l}5 \equiv 8 \\
5 \equiv 1\end{array}$ & & & & & $\begin{array}{l}34.4 \\
31.9\end{array}$ & $\begin{array}{l}30.6 \\
30.0\end{array}$ & $\begin{array}{l}443 \\
434\end{array}$ & $\begin{array}{r}+17.7 \\
+18.2\end{array}$ \\
\hline
\end{tabular}


Table 5 (zontinued)

\begin{tabular}{|c|c|c|c|c|c|c|c|c|c|c|c|c|}
\hline \multirow[b]{2}{*}{ Gage } & \multirow[b]{2}{*}{ type } & \multirow[b]{2}{*}{$\begin{array}{l}\text { Gage } \\
\text { No. }\end{array}$} & \multirow[b]{2}{*}{$\begin{array}{l}\text { Mix } \\
\text { No. }\end{array}$} & \multirow[b]{2}{*}{$\begin{array}{l}\text { Calitration } \\
\text { factor } \\
\text { supflied }\end{array}$} & \multicolumn{4}{|c|}{ Initial load cycle } & \multicolumn{4}{|c|}{ Failure load cycle } \\
\hline & & & & & $\begin{array}{l}\text { Maximum } \\
\text { stress } \\
\text { level } \\
(\mathrm{MPa})\end{array}$ & $\begin{array}{l}\text { Elastic } \\
\text { modulus } \\
(\mathrm{GPa})\end{array}$ & $\begin{array}{l}\text { Calculated } \\
\text { calibration } \\
\text { factor }\end{array}$ & $\begin{array}{c}\text { Calibration } \\
\text { factor } \\
\text { difference } \\
(\%)\end{array}$ & $\begin{array}{l}\text { Cylinder } \\
\text { failure } \\
\text { scress } \\
(\mathrm{MPa})\end{array}$ & $\begin{array}{c}\text { Elastic } \\
\text { modulus } \\
(\mathrm{GPa})\end{array}$ & $\begin{array}{l}\text { Calculated } \\
\text { calibration } \\
\text { factor }\end{array}$ & $\begin{array}{c}\text { Calibration } \\
\text { factor } \\
\text { difference } \\
(\%)\end{array}$ \\
\hline $\begin{array}{l}\text { Unbonded wire } \\
\text { (continued) }\end{array}$ & Type A & $\begin{array}{l}14 \\
15 \\
16 \\
17\end{array}$ & $\begin{array}{l}12^{b} \\
12^{b} \\
13^{c} \\
13^{c}\end{array}$ & $\begin{array}{l}539 \\
533 \\
544 \\
532\end{array}$ & $\begin{array}{l}17.1 \\
17.1 \\
12.2 \\
12.2\end{array}$ & $\begin{array}{l}25.0 \\
27.4 \\
28.7 \\
28.3\end{array}$ & $\begin{array}{l}507 \\
474 \\
453 \\
361\end{array}$ & $\begin{array}{r}+5.9 \\
+11.1 \\
+16.7 \\
+32.1\end{array}$ & $\begin{array}{l}27.9 \\
28.2 \\
29.2 \\
25.6\end{array}$ & $\begin{array}{l}23.8 \\
26.1 \\
30.3 \\
28.8\end{array}$ & $\begin{array}{l}504 \\
471 \\
454 \\
356\end{array}$ & $\begin{array}{r}+6.5 \\
+11.6 \\
+16.5 \\
+33.1\end{array}$ \\
\hline Unsonded wire & Type $\mathrm{E}$ & $\begin{array}{l}1 \\
2 \\
3 \\
4\end{array}$ & $\begin{array}{r}3 \\
17 \\
20 \\
20\end{array}$ & $\begin{array}{l}636 \\
655 \\
617 \\
638\end{array}$ & $\begin{array}{l}17.1 \\
14.6 \\
14.6 \\
14.6\end{array}$ & $\begin{array}{l}26.8 \\
24.4 \\
30.5 \\
31.2\end{array}$ & $\begin{array}{l}504 \\
551 \\
573 \\
579\end{array}$ & $\begin{array}{r}+20.8 \\
+15.9 \\
+7.1 \\
+9.2\end{array}$ & $\begin{array}{l}26.0 \\
25.9 \\
37.0 \\
36.6\end{array}$ & $\begin{array}{l}23.9 \\
24.4 \\
30.5 \\
30.3\end{array}$ & $\begin{array}{l}515 \\
566 \\
545 \\
581\end{array}$ & $\begin{array}{r}+19.0 \\
+13.6 \\
+11.7 \\
+8.9\end{array}$ \\
\hline U.tonded wire & Type C & $\begin{array}{l}1 \\
2 \\
3 \\
4\end{array}$ & $\begin{array}{l}20 \\
20 \\
20 \\
14\end{array}$ & $\begin{array}{l}2.43 \\
2.34 \\
2.44 \\
2.52\end{array}$ & $\begin{array}{l}14.6 \\
14.6 \\
14.6 \\
17.1\end{array}$ & $\begin{array}{l}30.9 \\
29.2 \\
33.1 \\
32.3\end{array}$ & $\begin{array}{l}2.33 \\
2.46 \\
2.85 \\
2.84\end{array}$ & $\begin{array}{r}+4.1 \\
-5.1 \\
-16.8 \\
-12.7\end{array}$ & $\begin{array}{l}41.1 \\
38.3 \\
38.7 \\
31.4\end{array}$ & $\begin{array}{l}31.5 \\
31.4 \\
33.5 \\
30.9\end{array}$ & $\begin{array}{l}2.60 \\
2.55 \\
3.05 \\
2.80\end{array}$ & $\begin{array}{r}-7.0 \\
-9.0 \\
-25.0 \\
-13.5\end{array}$ \\
\hline \multicolumn{13}{|l|}{ Vibrating wire } \\
\hline Wisg Type $A$ & & $\begin{array}{l}1 \\
2 \\
3\end{array}$ & $\begin{array}{l}1 \\
3 \\
3\end{array}$ & $\begin{array}{l}0.96 \times 10^{-3} \\
0.96 \times 10^{-3} \\
0.96 \times 10^{-3}\end{array}$ & $\begin{array}{l}17.1 \\
17.1 \\
17.1\end{array}$ & $\begin{array}{l}36.0 \\
25.7 \\
27.7\end{array}$ & $\begin{array}{l}0.60 \times 10^{-3} \\
0.75 \times 10^{-3} \\
0.77 \times 10^{-3}\end{array}$ & $\begin{array}{l}+37.5 \\
+21.9 \\
+19.8\end{array}$ & $\begin{array}{l}34.1 \\
25.9 \\
26.8\end{array}$ & $\begin{array}{l}34.8 \\
27.6 \\
23.5\end{array}$ & $\begin{array}{l}0.64 \times 10^{-3} \\
0.78 \times 10^{-3} \\
0.72 \times 10^{-3}\end{array}$ & $\begin{array}{l}+33.3 \\
+18.8 \\
+25.0\end{array}$ \\
\hline WWSG Type B & & $\begin{array}{l}1 \\
2\end{array}$ & $\begin{array}{l}1 \\
2\end{array}$ & $\begin{array}{l}3.00 \times 10^{-3} \\
3.00 \times 10^{-3}\end{array}$ & $\begin{array}{l}17.1 \\
17.1\end{array}$ & $\begin{array}{l}34.8 \\
28.0\end{array}$ & $\begin{array}{l}2.75 \times 10^{-3} \\
2.44 \times 10^{-3}\end{array}$ & $\begin{array}{r}+8.3 \\
+18.7\end{array}$ & $\begin{array}{l}34.1 \\
23.9\end{array}$ & $\begin{array}{l}32.9 \\
25.1\end{array}$ & $\begin{array}{l}2.58 \times 10^{-3} \\
2.71 \times 10^{-3}\end{array}$ & $\begin{array}{r}+14.0 \\
+9.7\end{array}$ \\
\hline IW'SG Type C & & $\begin{array}{l}1 \\
2 \\
3 \\
4 \\
5\end{array}$ & $\begin{array}{l}14 \\
14 \\
18 \\
20 \\
20\end{array}$ & $\begin{array}{l}\text { NA } \\
\text { NA } \\
\text { NA } \\
\text { NA } \\
\text { NA }\end{array}$ & $\begin{array}{l}17.1 \\
17.1 \\
14.6 \\
14.6 \\
14.6\end{array}$ & $\begin{array}{l}30.6 \\
28.3 \\
27.3 \\
30.5 \\
32.8\end{array}$ & $\begin{array}{l}3.17 \times 10^{-3} \\
3.64 \times 10^{-3} \\
3.35 \times 10^{-3} \\
3.68 \times 10^{-3} \\
3.35 \times 10^{-3}\end{array}$ & $\begin{array}{l}+41.0^{d} \\
+19.7^{d} \\
+27.5 d \\
+19.7^{d} \\
+28.9 d\end{array}$ & $\begin{array}{l}30.3 \\
31.9 \\
29.9 \\
39.2 \\
37.8\end{array}$ & $\begin{array}{l}28.7 \\
26.4 \\
26.7 \\
31.9 \\
33.4\end{array}$ & $\begin{array}{l}3.37 \times 10^{-3} \\
3.76 \times 10^{-3} \\
3.59 \times 10^{-3} \\
3.68 \times 10^{-3} \\
3.49 \times 10^{-3}\end{array}$ & $\begin{array}{l}+27.6^{d} \\
+17.4^{d} \\
+29.4 d \\
+25.4 d \\
+30.5^{d}\end{array}$ \\
\hline WWSG Type D & & $\begin{array}{l}1 \\
2\end{array}$ & $\begin{array}{r}1 \\
17\end{array}$ & $\begin{array}{l}2.60 \times 10^{-3} \\
2.60 \times 10^{-3}\end{array}$ & $\begin{array}{l}17.1 \\
14.6\end{array}$ & $\begin{array}{l}32.9 \\
27.4\end{array}$ & $\begin{array}{l}3.00 \times 10^{-3} \\
2.82 \times 10^{-3}\end{array}$ & $\begin{array}{r}-15.4 \\
-8.5\end{array}$ & $\begin{array}{l}34.0 \\
26.0\end{array}$ & $\begin{array}{l}29.9 \\
27.7\end{array}$ & $\begin{array}{l}3.03 \times 10^{-3} \\
2.89 \times 10^{-3}\end{array}$ & $\begin{array}{l}-16.5 \\
-11.2\end{array}$ \\
\hline VWSG Type E & & $\frac{1}{2}$ & $\begin{array}{l}1 \\
2\end{array}$ & $\begin{array}{l}2.0 \equiv \times 10^{-3} \\
2.0=\times 10^{-3}\end{array}$ & $\begin{array}{l}17.1 \\
17.1\end{array}$ & $\begin{array}{l}31.9 \\
26.1\end{array}$ & $\begin{array}{l}1.75 \times 10^{-3} \\
1.83 \times 10^{-3}\end{array}$ & $\begin{array}{r}+12.9 \\
+9.0\end{array}$ & $\begin{array}{l}33.2 \\
24.4\end{array}$ & $\begin{array}{l}30.1 \\
21.8\end{array}$ & $\begin{array}{l}1.68 \times 10^{-3} \\
1.90 \times 10^{-3}\end{array}$ & $\begin{array}{r}+16.4 \\
+5.5\end{array}$ \\
\hline DNSG Type $F$ & & $\begin{array}{l}1 \\
2 \\
3 \\
4 \\
5\end{array}$ & $\begin{array}{r}8 \\
18 \\
19 \\
1 \\
2\end{array}$ & $\begin{array}{l}1.20 \times 10^{-3} \\
1.20 \times 10^{-3} \\
1.20 \times 10^{-3} \\
1.24 \times 10^{-3} \\
1.24 \times 10^{-3}\end{array}$ & $\begin{array}{l}17.1 \\
14.6 \\
14.6 \\
17.1 \\
17.1\end{array}$ & $\begin{array}{l}30.5 \\
26.1 \\
27.7 \\
30.9 \\
27.4\end{array}$ & $\begin{array}{l}1.15 \times 10^{-3} \\
1.00 \times 10^{-3} \\
1.07 \times 10^{-3} \\
0.98 \times 10^{-3} \\
1.08 \times 10^{-3}\end{array}$ & $\begin{array}{r}+4.2 \\
+16.7 \\
+10.8 \\
+21.0 \\
+12.9\end{array}$ & $\begin{array}{l}38.5 \\
26.7 \\
33.2 \\
34.5 \\
25.9\end{array}$ & $\begin{array}{l}29.6 \\
24.4 \\
25.6 \\
28.8 \\
23.5\end{array}$ & $\begin{array}{l}1.10 \times 10^{-3} \\
0.95 \times 10^{-3} \\
1.07 \times 10^{-3} \\
1.00 \times 10^{-3} \\
1.09 \times 10^{-3}\end{array}$ & $\begin{array}{r}+8.3 \\
+20.8 \\
+10.8 \\
+19.4 \\
+12.1\end{array}$ \\
\hline
\end{tabular}


Table. 5 (continued)

\begin{tabular}{|c|c|c|c|c|c|c|c|c|c|c|c|}
\hline \multirow[b]{2}{*}{ Gage type } & \multirow[b]{2}{*}{$\begin{array}{l}\text { Gage } \\
\text { No. }\end{array}$} & \multirow[b]{2}{*}{$\begin{array}{l}\text { Mix } \\
\text { No. }\end{array}$} & \multirow[b]{2}{*}{$\begin{array}{l}\text { Calibration } \\
\text { factor } \\
\text { supplied }\end{array}$} & \multicolumn{4}{|c|}{ Initial load cycle } & \multicolumn{4}{|c|}{ Failure load sycle } \\
\hline & & & & $\begin{array}{l}\text { Mayimum } \\
\text { stress } \\
\text { level } \\
\text { (MFa) }\end{array}$ & $\begin{array}{l}\text { Elestic } \\
\text { močulus } \\
(\mathrm{CPa})\end{array}$ & $\begin{array}{l}\text { Calculated } \\
\text { calibration } \\
\text { factor }\end{array}$ & $\begin{array}{l}\text { Calibration } \\
\text { factor } \\
\text { difference } \\
(\%)\end{array}$ & $\begin{array}{c}\text { Cylinder } \\
\text { faildre } \\
\text { stræse } \\
\text { (MP.a) }\end{array}$ & $\begin{array}{l}\text { Elastic } \\
\text { modulus } \\
(\mathrm{GPa})\end{array}$ & $\begin{array}{l}\text { Calculated } \\
\text { calibration } \\
\text { factor }\end{array}$ & $\begin{array}{c}\text { Calibration } \\
\text { factor } \\
\text { difference } \\
(\%)\end{array}$ \\
\hline VWSG Type G & $\begin{array}{r}1 \\
2 \\
3 \\
4 \\
5 \\
5 \\
7 \\
3 \\
9 \\
10 \\
11 \\
12\end{array}$ & $\begin{array}{l}4 \\
4 \\
4 \\
2 C \\
16 \\
16 \\
15 \\
15 \\
12^{b} \\
12^{b} \\
13^{c} \\
13^{c}\end{array}$ & $\begin{array}{l}3.00 \times 10^{-3} \\
3.00 \times 10^{-3} \\
3.00 \times 10^{-3} \\
3.00 \times 10^{-3} \\
3.00 \times 10^{-3} \\
3.00 \times 10^{-3} \\
3.00 \times 10^{-3} \\
3.00 \times 10^{-3} \\
3.00 \times 10^{-3} \\
3.00 \times 10^{-3} \\
3.00 \times 10^{-3} \\
3.00 \times 10^{-3}\end{array}$ & $\begin{array}{r}17.1 \\
17.1 \\
17.1 \\
14.6 \\
9.8 \\
9.8 \\
17.1 \\
17.1 \\
17.1 \\
17.1 \\
12.2 \\
12.2\end{array}$ & $\begin{array}{l}3 \text { C. } 2 \\
28.7 \\
3 a .9 \\
29.3 \\
23.5 \\
25.2 \\
39.9 \\
37.0 \\
25.8 \\
29.8 \\
21.8 \\
23.2\end{array}$ & $\begin{array}{l}2.37 \times 10^{-3} \\
2.26 \times 10^{-3} \\
2.25 \times 10^{-3} \\
2.65 \times 10^{-3} \\
2.63 \times 10^{-3} \\
2.16 \times 10^{-3} \\
2.19 \times 10^{-3} \\
2.22 \times 10^{-3} \\
2.22 \times 10^{-3} \\
2.27 \times 10^{-3} \\
2.25 \times 10^{-3} \\
2.36 \times 10^{-3}\end{array}$ & $\begin{array}{l}+21.0 \\
+24.7 \\
+25.0 \\
+11.7 \\
+12.3 \\
+28.0 \\
+27.0 \\
+26.0 \\
+26.0 \\
+24.3 \\
+25.0 \\
+21.3\end{array}$ & $\begin{array}{l}33.0 \\
28.1 \\
34.3 \\
38.3 \\
19.0 \\
16.6 \\
41.5 \\
41.6 \\
325 \\
31.7 \\
24.2 \\
23.3\end{array}$ & $\begin{array}{l}27.8 \\
24.8 \\
29.2 \\
30.3 \\
21.4 \\
24.9 \\
39.2 \\
37.0 \\
27.1 \\
27.3 \\
23.4 \\
24.4\end{array}$ & $\begin{array}{l}2.33 \times 10^{-3} \\
2.14 \times 10^{-3} \\
2.24 \times 10^{-3} \\
2.50 \times 10^{-3} \\
2.63 \times 10^{-3} \\
1.82 \times 10^{-3} \\
2.14 \times 10^{-3} \\
2.23 \times 10^{-3} \\
2.23 \times 10^{-3} \\
2.31 \times 10^{-3} \\
2.52 \times 10^{-3} \\
2.24 \times 10^{-3}\end{array}$ & $\begin{array}{l}+20.7 \\
+28.7 \\
+25.3 \\
+16.7 \\
+10.7 \\
+39.3 \\
+28.7 \\
+25.7 \\
+25.7 \\
+23.0 \\
+15.0 \\
+25.3\end{array}$ \\
\hline
\end{tabular}

$a_{\text {percent difference }}=[$ (gage factor supplied - gage factor calzulated)/gage factor supplied] $\times 100 \%$.

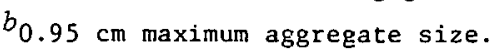

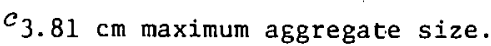

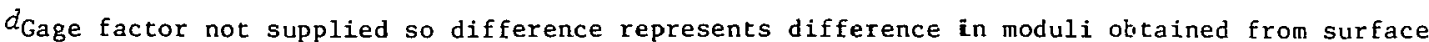
sages and from manufactirer's calibration table. 
$3.81 \mathrm{~cm}$ maximum aggregate sizes.* Gage-length-to-maximum-aggregate size ratios thus varied from 2.7 to 10.6 for the specimens containing the unbonded-wire Type A gages and from 3.5 to 14.0 for those containing: the VWSG Type G gages. Casting, curing, and testing of the specimens followed the same procedure as for the calibration specimens.

Table 6 presents a summary of the results obtained from the test series. As the gage-length-to-maximum-aggregate size ratio for the unbonded Type A meter changed from 10.6 to 5.3 to 2.1 , the average percent difference between manufacturer-supplied calibration factors and experimentally determined calibration factors increased from 9.1 to 16.6 to 24.8; however, for the VWSG Type G meter where the ratio changed from 14.0 to 7.0 to.3.5, the calibration factor average percent differences remained relatively constant at $24.4,24.9$, and 20.6, respectively. Relative results obtained from the embedded gages and from the surface wire resistance strain gages used by Cooke and Seddon, ${ }^{1}$ Binns and Mygind, 12 and Peattie ${ }^{13}$ are presented in Fig. 84. Similar trends are apparent for both the wire resistance and embedded gages. Offset of embedded gage data from surface strain gage data is a function of both the type of embedded gage (modular ratio) and the fact that the gages are measuring internal rather than surface strains. The data thus verify that the ratio of meter gage-length-to-maximum-aggregate size should be at least 3.5 .

Effect of modular ratio $\left(E_{m} / E_{c}\right)$ on embedded strain meter performance

Equation (2) presents the theoretical error in strain indicated by long, slender, cylindrical meters embedded in an infinitely large homogeneous, linear elastic body. Figure 2, which is a graphical representation of Eq. (2), shows that for meters with constant length-to-radius ratios, the magnitude of the error in indicated strain increases as the modular ratio $\left(E_{m} / E_{c}\right)$ increases (negative error) or decreases (positive error) from unity. Theoretical errors have been calculated for the gages

*Aggregate gradations for the $0.95,1.91$, and $3.81 \mathrm{~cm}$ maximum aggregate size mixes are presented in Tahle 3 as Series $C, A$, and D mixes, respectively. 
Table 6. Summary of test results for effect on meter performance c.f gage-len:th to maximum-aggregate size ratio

\begin{tabular}{|c|c|c|c|c|c|c|c|c|c|c|}
\hline \multirow[b]{2}{*}{$\begin{array}{l}\text { Mix } \\
\text { No. }\end{array}$} & \multirow[b]{2}{*}{$\begin{array}{l}\text { Gage length- } \\
\text { to-diameter } \\
\text { ratio }\end{array}$} & \multirow[b]{2}{*}{$\begin{array}{l}\text { Calibration } \\
\text { factor } \\
\text { supflied }\end{array}$} & \multicolumn{4}{|c|}{ Ini-ial load cycle } & \multicolumn{4}{|c|}{ Failure load cycle } \\
\hline & & & $\begin{array}{l}\text { MaximLm } \\
\text { stress } \\
\text { leve] } \\
\text { (MFa: }\end{array}$ & $\begin{array}{l}\text { Elastic } \\
\text { modulus } \\
\text { (GPa) }\end{array}$ & $\begin{array}{c}\text { Calculazed } \\
\text { calibrazion } \\
\text { faoto: }\end{array}$ & $\begin{array}{c}\text { Calibration } \\
\text { factor } \\
\text { difference } \\
(\%)\end{array}$ & $\begin{array}{l}\text { Cylinder } \\
\text { failure } \\
\text { stress } \\
\text { (MPa) }\end{array}$ & $\begin{array}{c}\text { Elastic } \\
\text { modulus } \\
(\mathrm{GPa})\end{array}$ & $\begin{array}{l}\text { Calculated } \\
\text { calibration } \\
\text { factor }\end{array}$ & $\begin{array}{c}\text { Calibration } \\
\text { factor } \\
\text { difference } \\
(\%)\end{array}$ \\
\hline \multicolumn{11}{|c|}{ Unbonded wire Type A } \\
\hline 12 & 10.6 & 539 & 17.1 & 25.0 & 537 & +5.9 & 27.9 & 23.8 & 504 & +6.5 \\
\hline 12 & 10.6 & 533 & 17.1 & 27.4 & 474 & +11.1 & 28.2 & 26.1 & 471 & +11.6 \\
\hline 2 & 5.3 & 528 & 17.1 & 25.8 & 422 & +20.1 & 24.9 & 20.8 & 429 & +18.8 \\
\hline 2 & 5.3 & 532 & 17.1 & 25.3 & 451 & +15.2 & 25.2 & 21.8 & 469 & +11.8 \\
\hline 4 & 5.3 & 536 & 17.1 & 29.7 & 449 & +16.2 & 33.0 & 26.3 & 433 & +19.2 \\
\hline 13 & 2.7 & 544 & 12.2 & 23.7 & 453 & +16.7 & 29.2 & 30.3 & 454 & +16.5 \\
\hline 13 & 2.7 & 532 & 12.2 & 23.3 & 351 & +32.1 & 25.6 & 28.8 & 356 & +33.1 \\
\hline \multicolumn{11}{|c|}{ VWSG Type G } \\
\hline 12 & 14.0 & $3.00 \times 10^{-3}$ & 17.1 & 28.8 & $2.22 \times 10^{-3}$ & +26.0 & 32.5 & 27.1 & $2.23 \times 10^{-3}$ & +25.7 \\
\hline 12 & 14.0 & $3.00 \times 10^{-3}$ & 17.1 & 29.8 & $2.27 \times 10^{-3}$ & +24.3 & 31.7 & 27.3 & $2.31 \times 10^{-3}$ & +23.0 \\
\hline 4 & 7.0 & $3.00 \times 10^{-3}$ & 17.1 & 30.2 & $2.3 \bar{T} \times 10^{-3}$ & +21.0 & 33.0 & 27.8 & $2.38 \times 10^{-3}$ & +20.7 \\
\hline 4 & 7.0 & $3.00 \times 10^{-3}$ & 17.1 & 28.7 & $2.26 \times 10^{-3}$ & +24.7 & 28.1 & 24.8 & $2.14 \times 10^{-3}$ & +28.7 \\
\hline 4 & 7.0 & $3.00 \times 10^{-3}$ & 17.1 & 30.9 & $2.25 \times 10^{-3}$ & +25.0 & 34.3 & 29.2 & $2.24 \times 10^{-3}$ & +25.3 \\
\hline 13 & 3.5 & $3.00 \times 10^{-3}$ & 12.2 & 21.8 & $2.25 \times 10^{-3}$ & +25.0 & 24.2 & 23.4 & $2.52 \times 10^{-3}$ & +16.0 \\
\hline 13 & 3.5 & $3.00 \times 10^{-3}$ & 12.2 & 23.2 & $2.36 \times 10^{-3}$ & +21.3 & 23.3 & 24.4 & $2.24 \times 10^{-3}$ & +25.3 \\
\hline
\end{tabular}

$a_{\text {Percent difference }}=[$ (gage factor supplied - sage factor calculated) $/$ gage factor suppliəd $] \times 100 \%$. 
evaluated in the calibration study; the results are summarized in Table 7. Differences between manufacturer-supplied and calculated calibration factors are also presented in the table. Theoretical errors in each case were less than experimentally determined differences between the embedded gages and the reference surface gages. This discrepancy was probably attributable to the idealization of both the concrete and the embedded meter when deriving the theoretical expression.

Two meters, unbonded-wire Type A and VWSG Type G, were further examined to see if an error trend could be established as a function of modular ratio. The meter selection was such that the Type A meter represented meters with a modular ratio less than 1 and the Type $G$ represented meters with a modular ratio greater than 1 . Unfortunately, the scatter in experimental data and the relatively small range in modular ratios did not allow for the establishment of a data trend for modular ratios.

\section{CONCLUSIONS}

This study was the first of a series in which instrumentation for embedment in concrete is being evaluated. The approach was divided into two phases, an overview of strain meters and the performance criteria which they must meet for PCPV application, and an experimental evaluation of the reliablity of manufacturer-supplied calibration factors. The following conclusions can be derived from the study:

1. Gage calibration factors should always be determined using representative samples from the particular batch of gages to be used.

2. Calibration test specimens should be of sufficient size to provide reliable results and should be fabricated using a representative concrete mix.

3. Gage selection should match the application; that 1s, a gage sultable for use in a model structure may not be suitable for a prototype structure due to insufficient gage length.

4. Results indicate that research should be conducted on other measurement techniques based on inductance, capacitance, semiconductors, and fluidic principles in an effort to improve meter accuracy. 
Table 7. Comparison of theoretical and experimental strain errors

\begin{tabular}{|c|c|c|c|c|c|c|}
\hline Gage type & $\begin{array}{l}\text { Gage } \\
\text { length } \\
\text { (cm.) }\end{array}$ & $\begin{array}{l}\text { Equivalent } \\
\text { cross-section } \\
\text { radius } \\
(\mathrm{cm})\end{array}$ & $\begin{array}{l}\text { Length-to- } \\
\text { radius ratio }\end{array}$ & $\begin{array}{l}\text { Modular ratio } \\
\text { range }\end{array}$ & $\begin{array}{l}\text { Theoretical } \\
\text { error } \\
(\%)\end{array}$ & $\begin{array}{c}\text { Experimentally } \\
\text { determined } \\
\text { differences } \\
(\%)\end{array}$ \\
\hline $\begin{array}{l}\text { Plastic encapsulated Type A } \\
\text { Plastic encapsulated Type B }\end{array}$ & $\begin{array}{r}6.0 \\
25.4\end{array}$ & $\begin{array}{l}0.45 \\
0.22\end{array}$ & $\begin{array}{r}13 \\
.113\end{array}$ & $\begin{array}{l}0.1100-0.1700 \\
0.0800-0.0900\end{array}$ & $\begin{array}{l}+9.0 \text { to }+9.6 \\
+1.2\end{array}$ & $\begin{array}{l}-11.8 \text { to }+26.5 \\
-1.0 \text { to }+11.0\end{array}$ \\
\hline Single wire & 10.2 & 0.05 & 200 & $1.8700-3.2400$ & -0.6 to -1.7 & -1.0 to +27.5 \\
\hline $\begin{array}{l}\text { Unbonded wire Type A } \\
\text { Unbonded wire Type B } \\
\text { Unbonded wire Type C }\end{array}$ & $\begin{array}{l}10.3 \\
10.0 \\
10.4\end{array}$ & $\begin{array}{l}0.80 \\
1.00 \\
5.00\end{array}$ & $\begin{array}{l}13 \\
10 \\
21\end{array}$ & $\begin{array}{l}0.0001-0.0002 \\
0.0088-0.0095 \\
0.0020-0.0030\end{array}$ & $\begin{array}{l}+12.0 \\
+15.7 \\
+7.3\end{array}$ & $\begin{array}{l}+1.3 \text { to }+33.1 \\
+8.9 \text { to }+19.0 \\
-7.0 \text { to }-25.0\end{array}$ \\
\hline $\begin{array}{l}\text { VWSG Type A } \\
\text { VWSG Type B } \\
\text { VWSG Type C } \\
\text { VWSG Type D } \\
\text { VWSG Type E } \\
\text { VWSG Type F } \\
\text { VWSG Type G }\end{array}$ & $\begin{array}{r}7.6 \\
14.0 \\
12.7 \\
12.7 \\
10.2 \\
8.9 \\
13.3\end{array}$ & $\begin{array}{l}0.32 \\
0.32 \\
0.79 \\
1.02 \\
0.71 \\
0.24 \\
0.32\end{array}$ & $\begin{array}{l}24 \\
44 \\
16 \\
12 \\
14 \\
37 \\
40\end{array}$ & $\begin{array}{l}0.1800-0.2700 \\
\text { Not available } \\
0.7800-1.0000 \\
1.1500-1.2500\end{array}$ & $\begin{array}{l}+4.6 \text { to }+5.2 \\
\text { J to }+2.0 \\
-1.7 \text { to }-2.8 \\
\text { J to }-1.3 \\
\text { J to }-2.2\end{array}$ & $\begin{array}{l}+18.8 \text { to }+33.3 \\
+9.7 \text { to }+14.0 \\
+17.4 \text { to }+30.5 \\
-11.2 \text { to }-16.5 \\
+5.5 \text { to }+16.4 \\
+8.3 \text { to }+20.8 \\
+10.7 \text { to }+39.3\end{array}$ \\
\hline
\end{tabular}




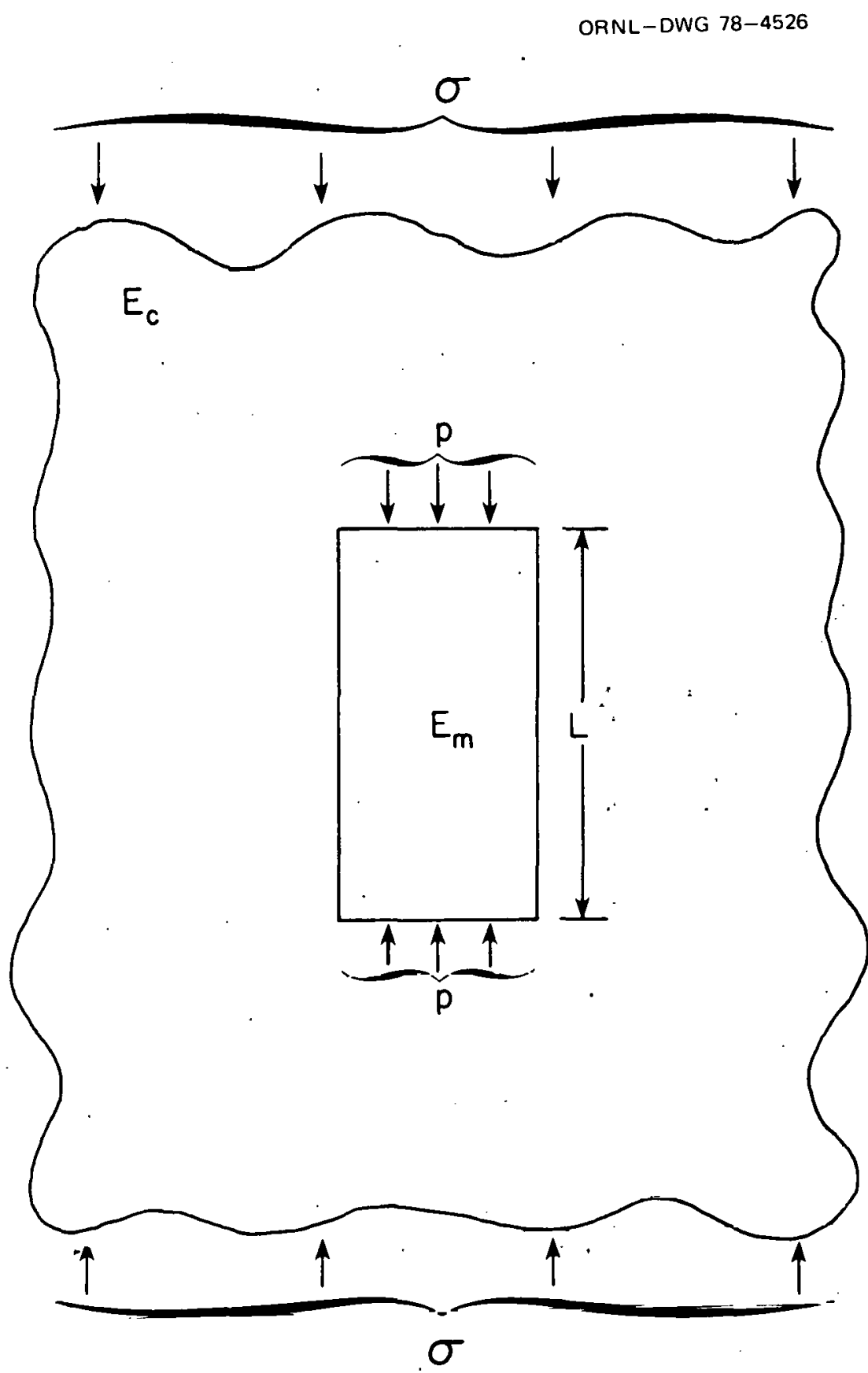

Fig. 1. Inclusion in a solid body. 


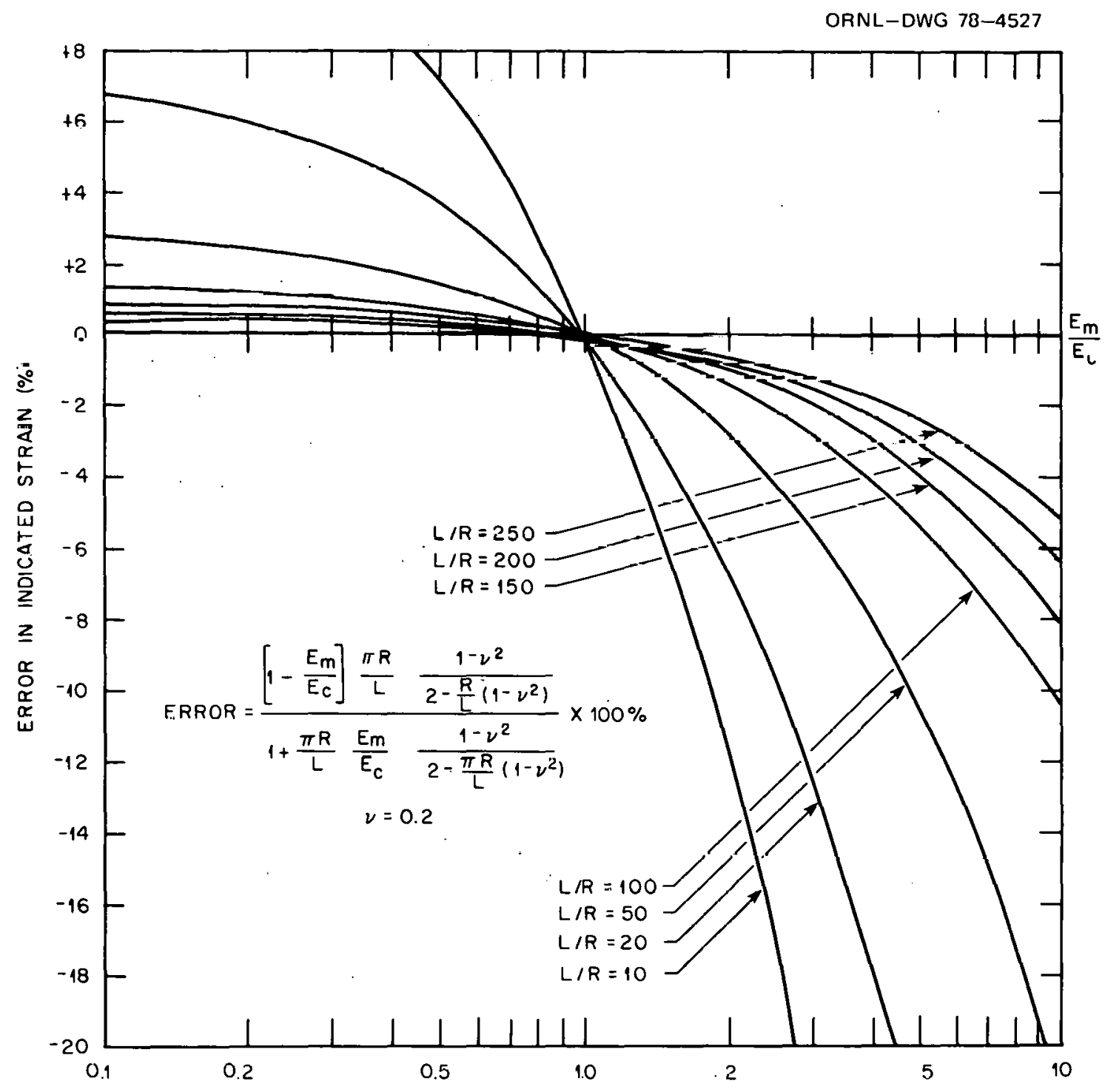

Fig. 2. Theoretical percentage error indicated by strain meters embedded in a solid as a function of slenderness ratio $(L / R)$ and modular. ratio $\left(E_{m} / E_{c}\right)$ for Poisson's ratio $=0.2$. 


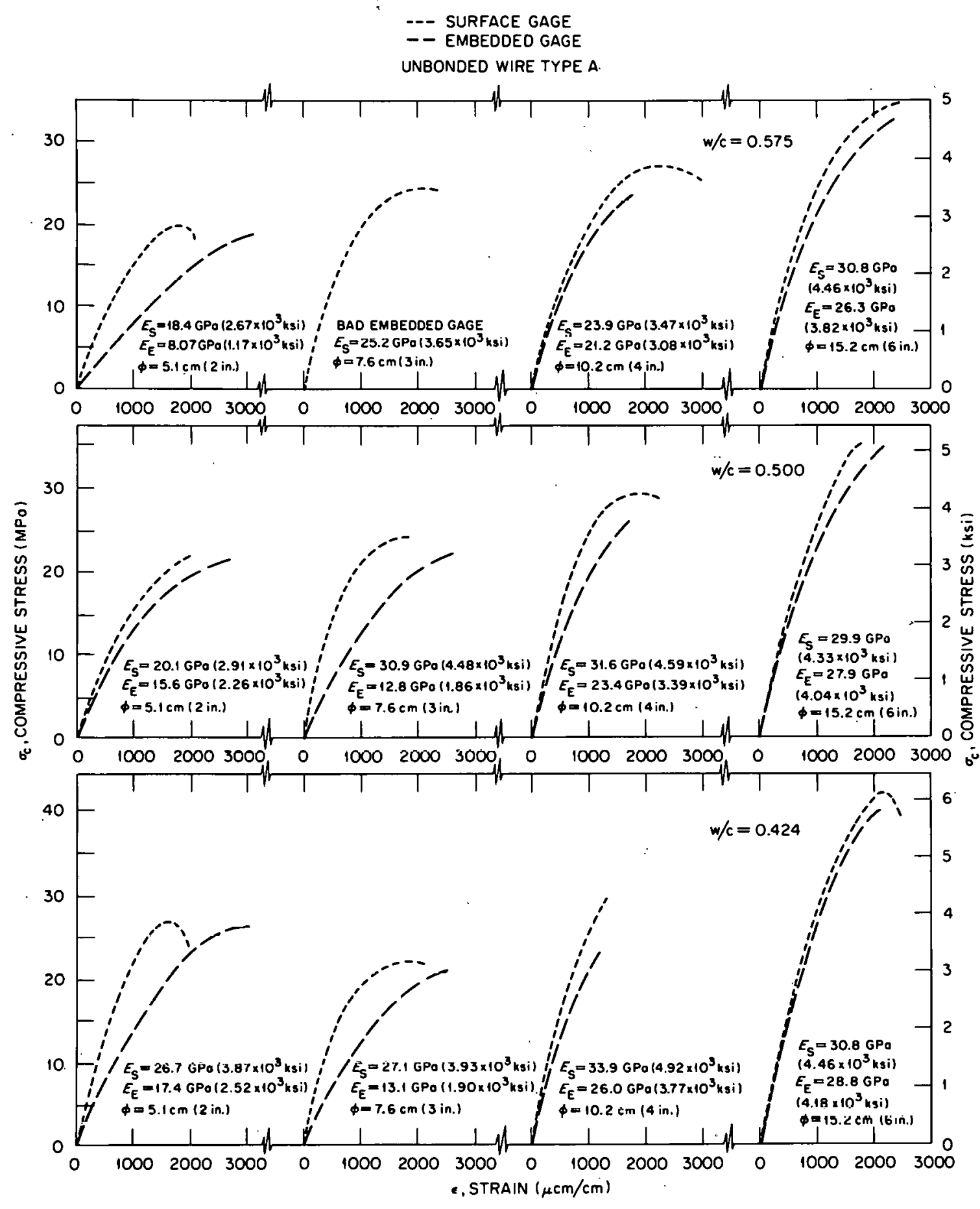

Fig. 3. Effect of specimen size and concrete strength on embedded gage performance ( $\mathrm{w} / \mathrm{c}=$ water-to-cement ratio by weight; $E_{\boldsymbol{g}}=$ Young's modulus obtained from surface strain gages; $E_{E}=$ Young's modulus obtained from embedded strain gages; $\phi=$ specimen diameter). 
ORNL-OWG 78-4447
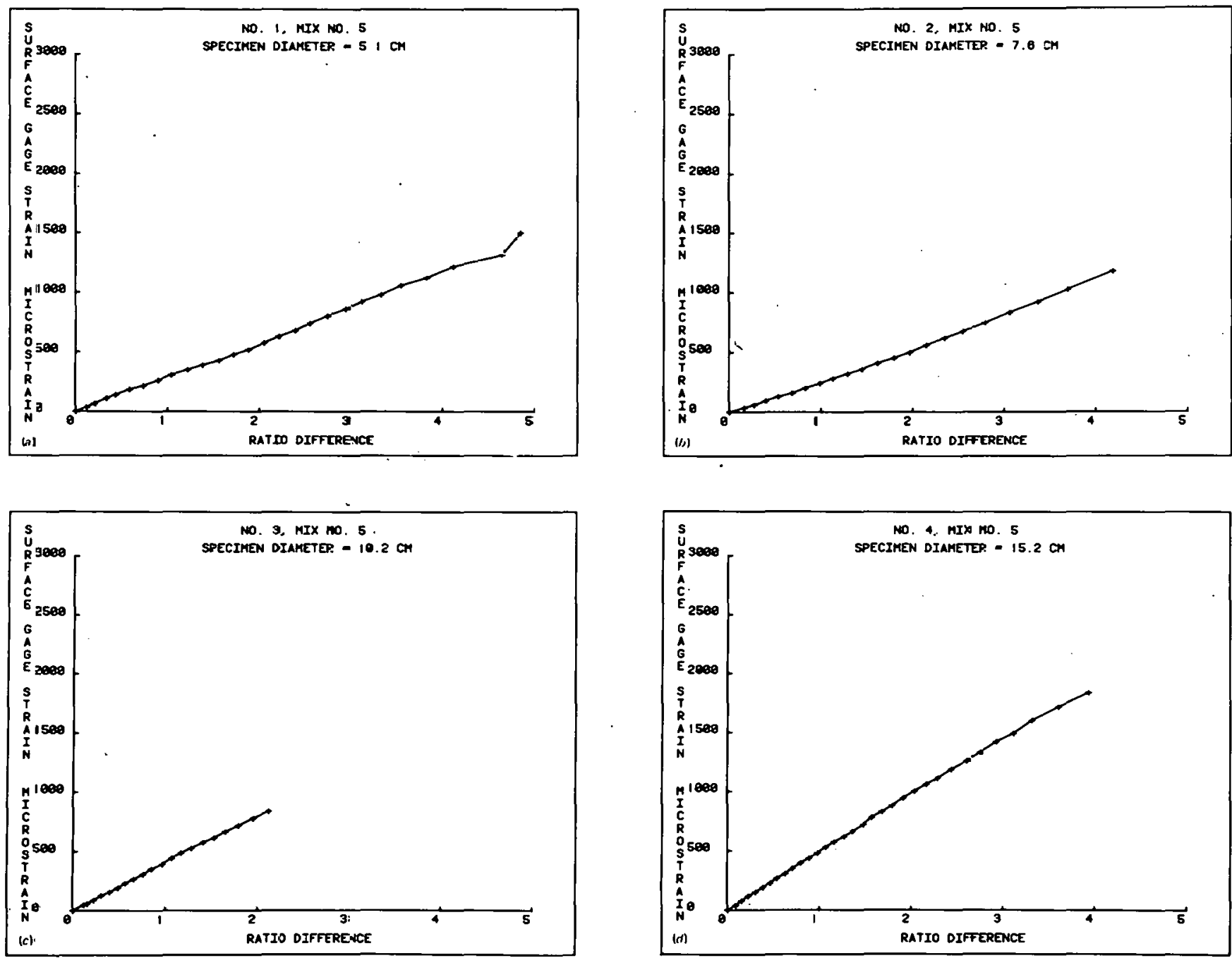

Fig. 4. Iffect of specimen size, mix 5. 

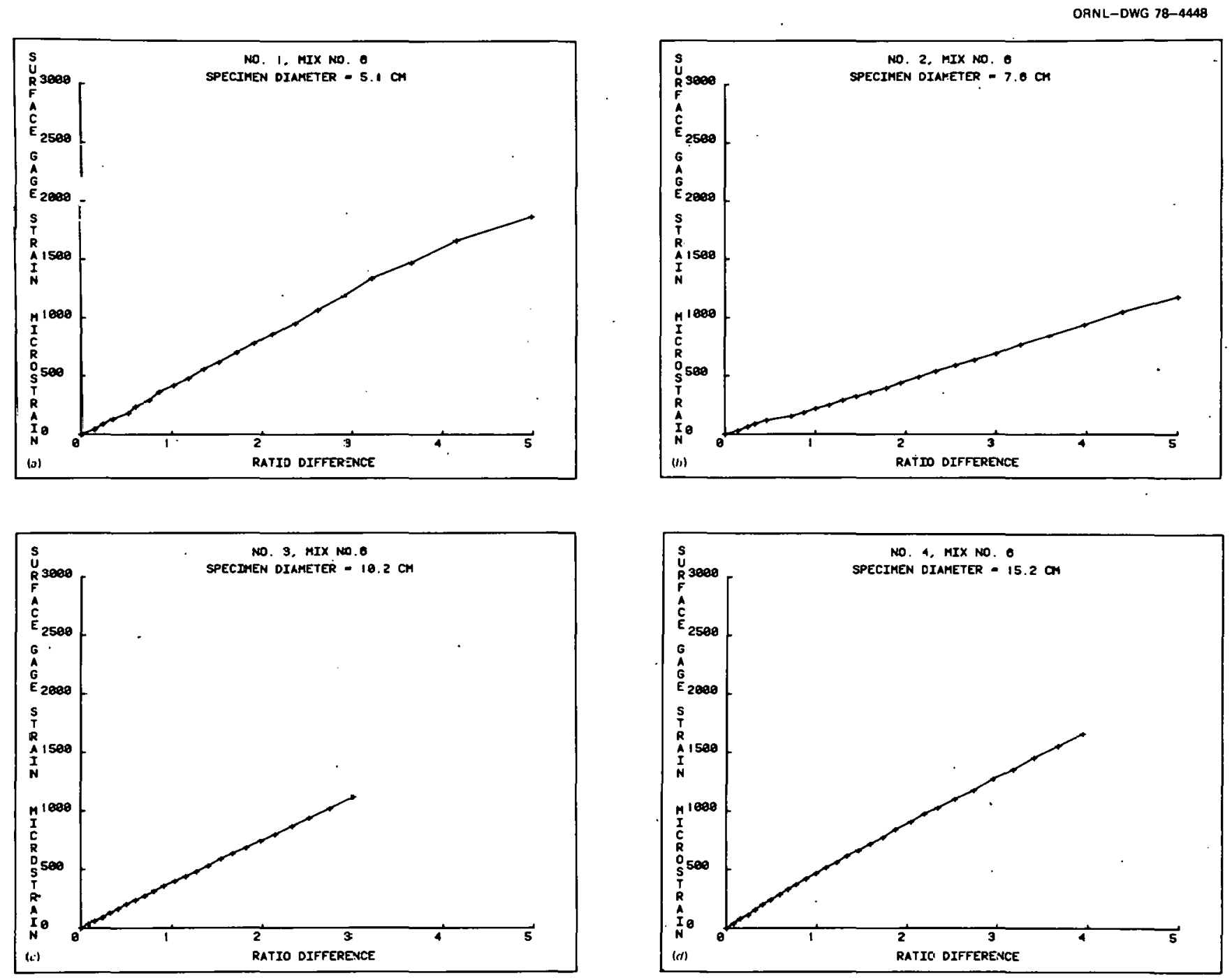

Fig. 5. Effect of specimen size, $\operatorname{mix} 6$. 
ORNL-OWG 78-4449
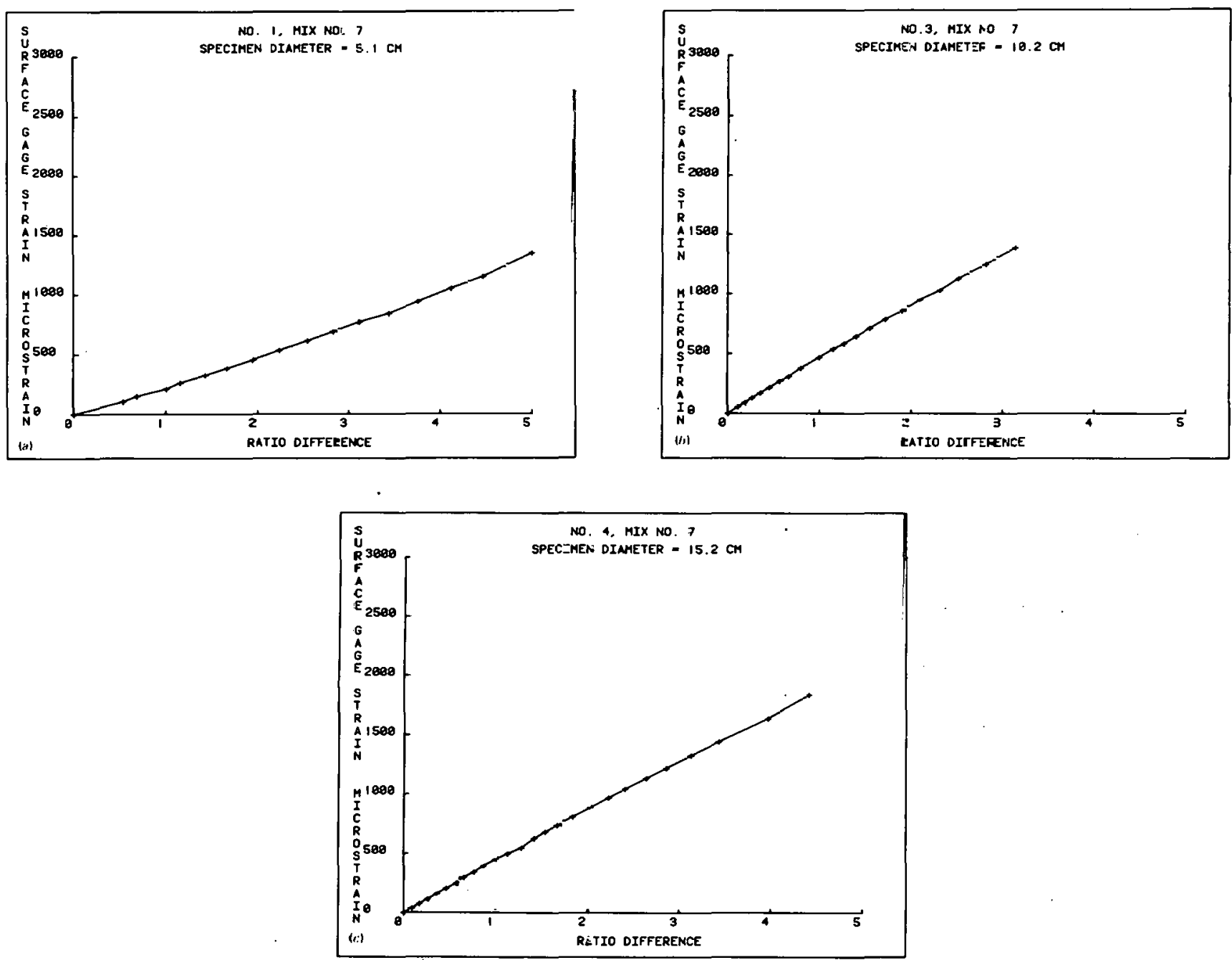

Fig. 6. Effect of specimen size, $\mathrm{mix} 7$ 


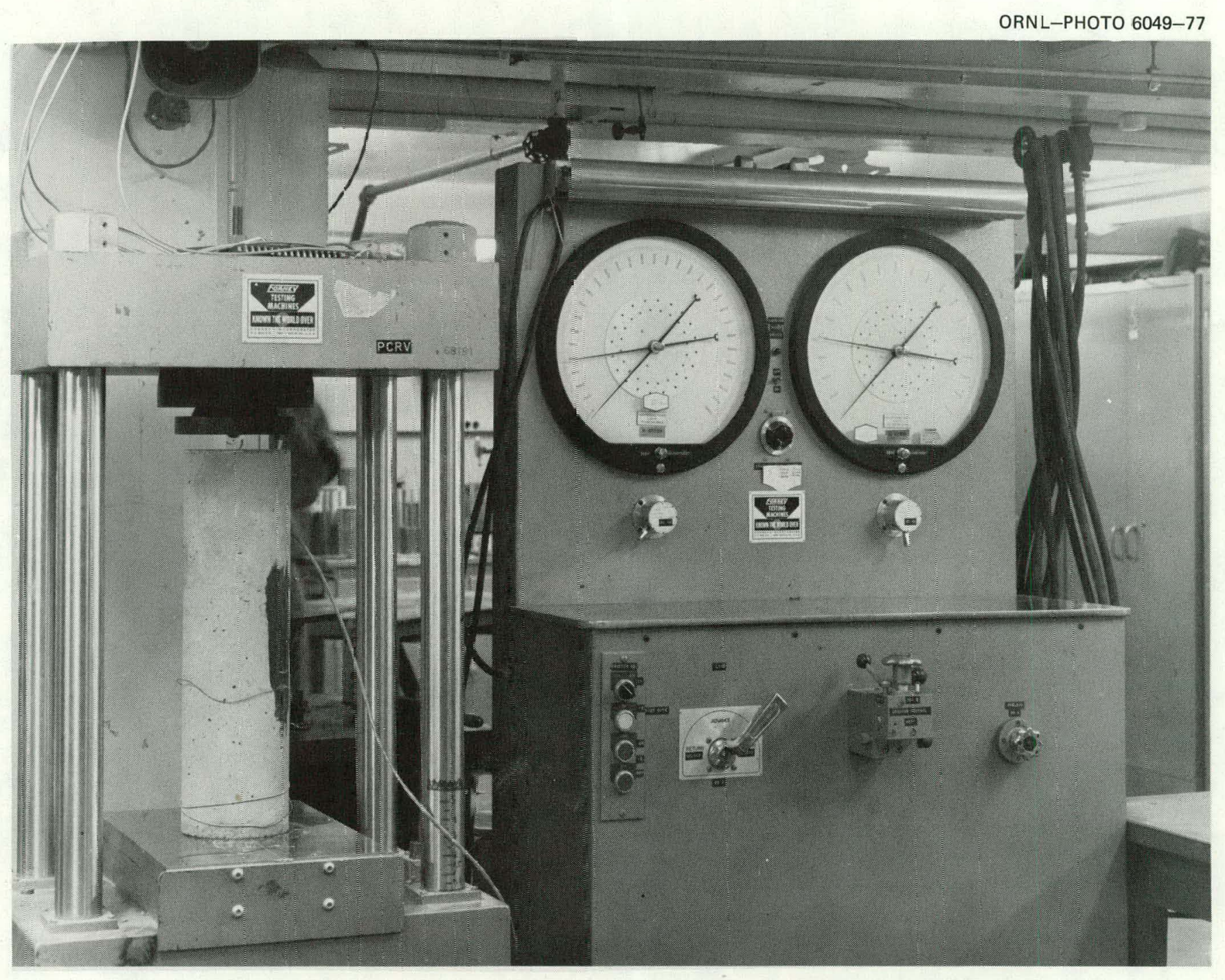

Fig. 7. Calibration test setup. 
ORNL-DWG 78-4450
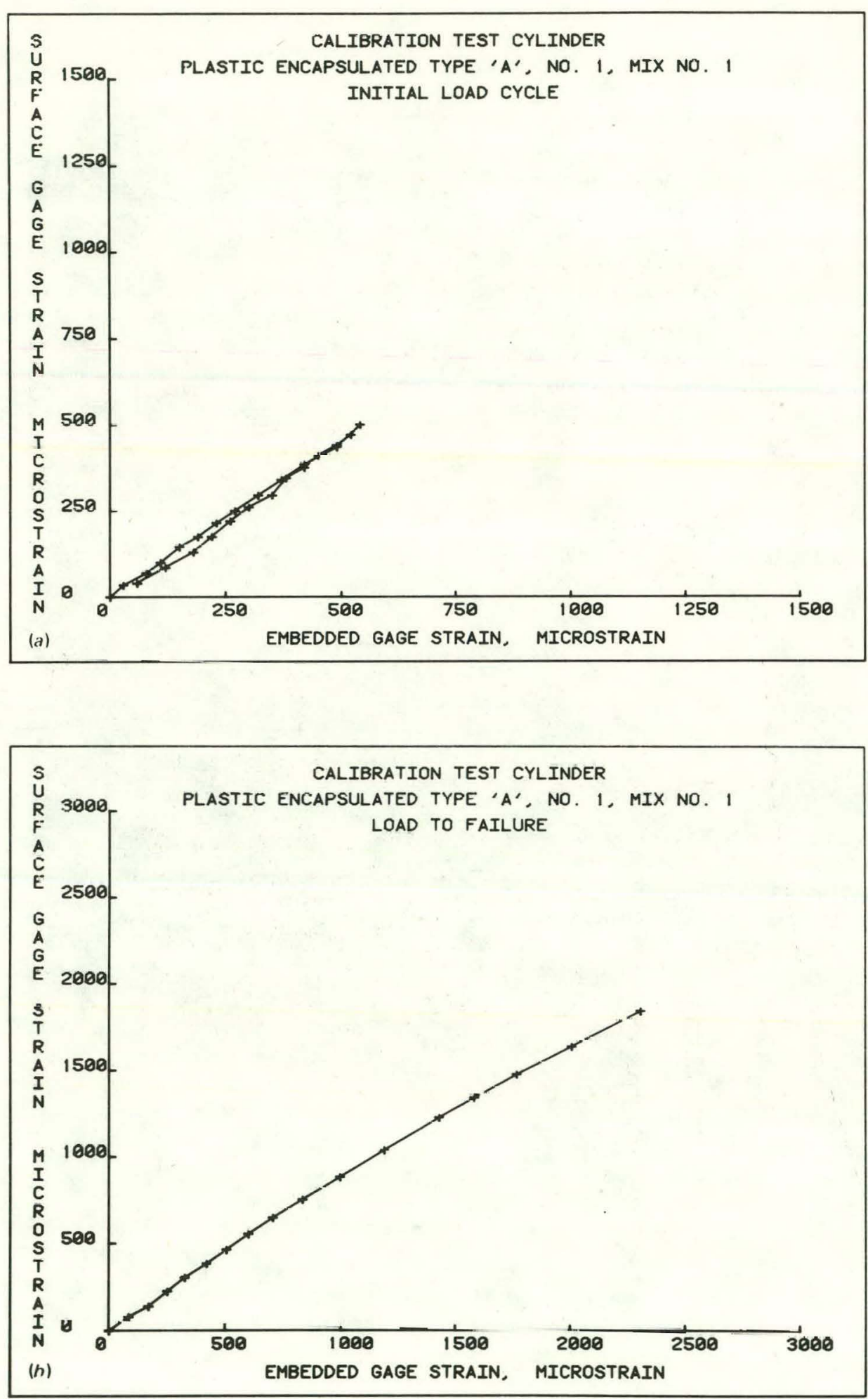

Fig. 8. Surface strain gage vs embedded gage output (plastic encapsulated gage, Type A, No. 1). 

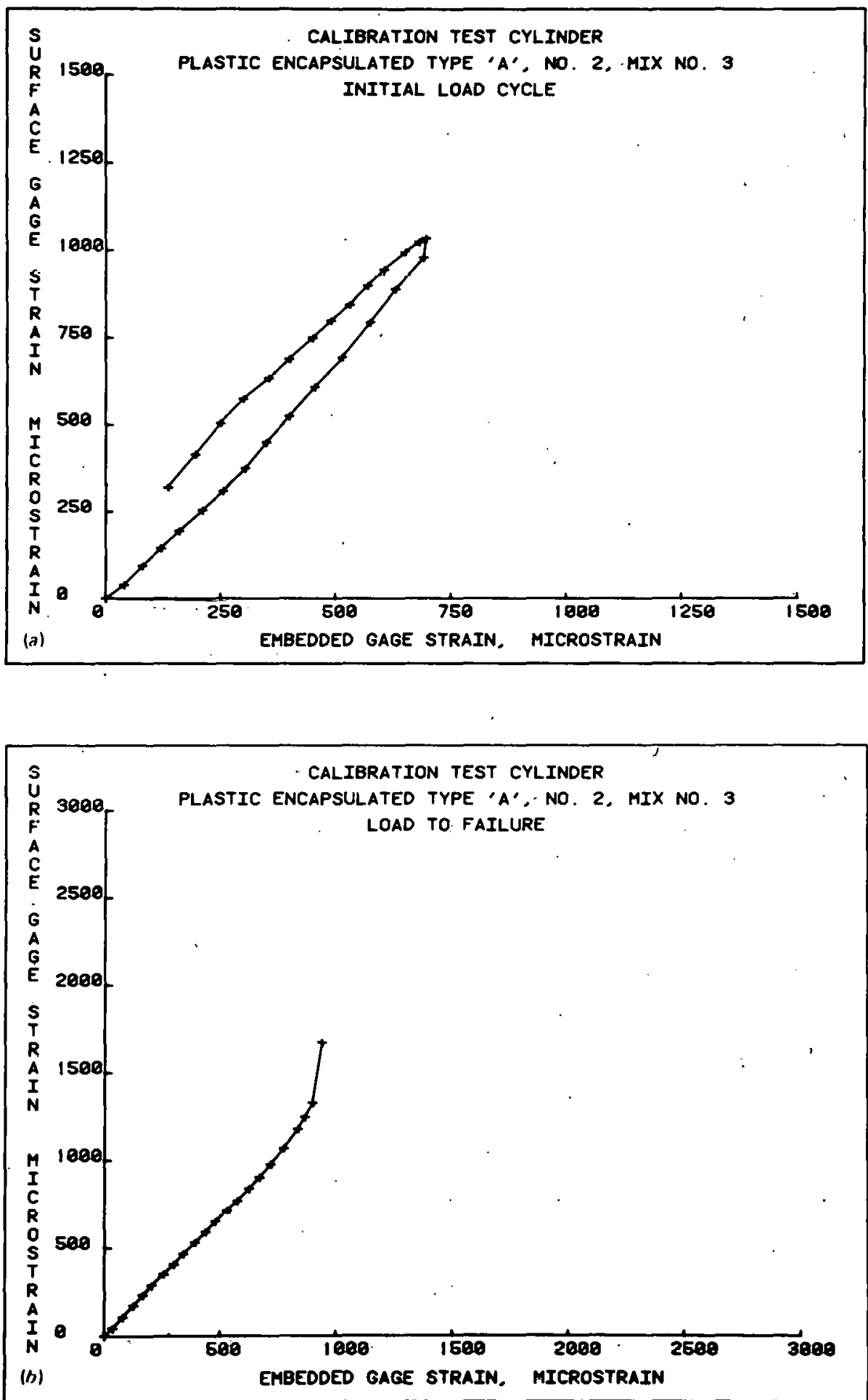

Fig. 9. Surface strain gage vs embedded gage output (plastic encapsulated gage, Type A, No. 2). 

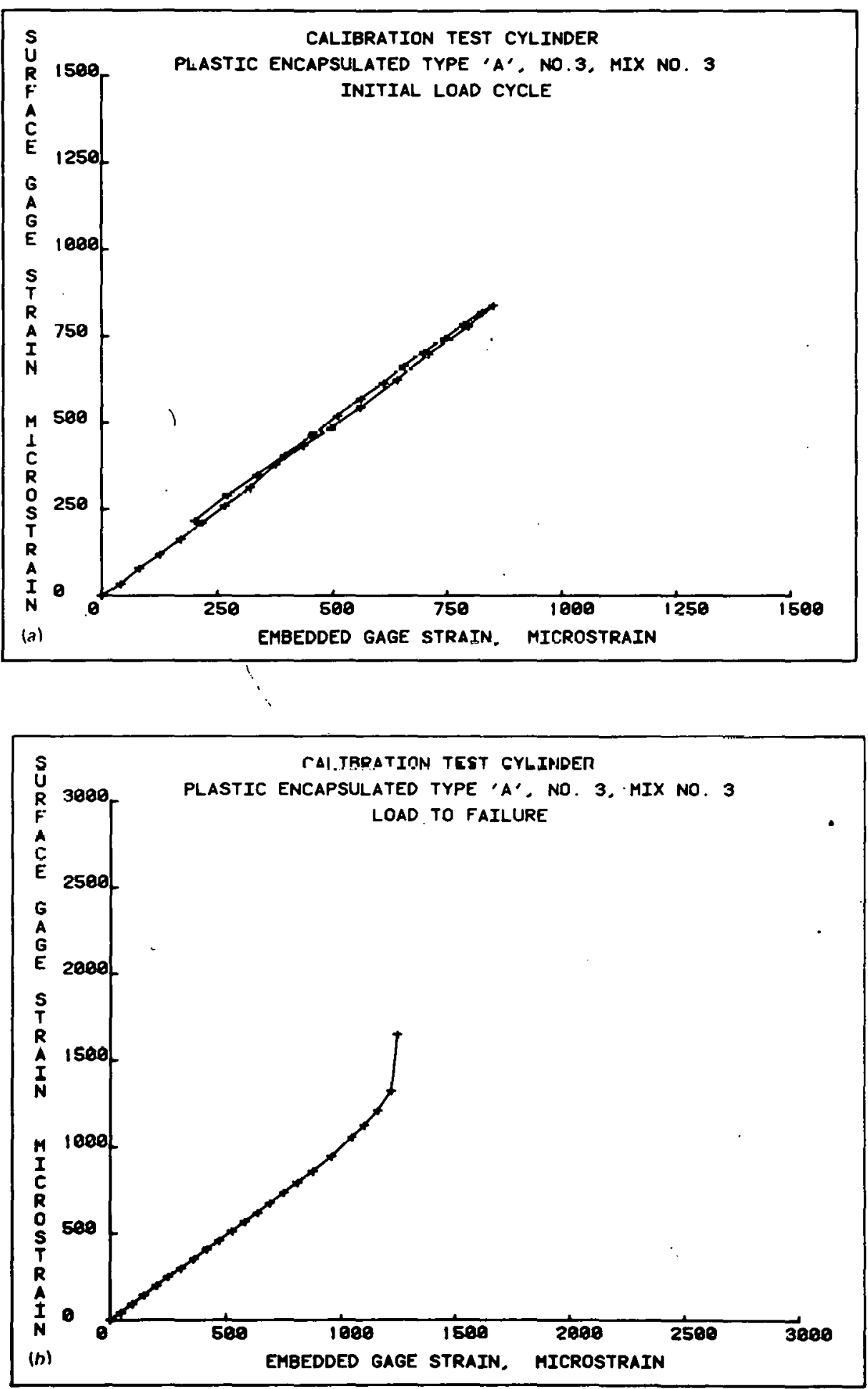

Fig. 10. Surface strain gage vs embedded gage output (plastic encapsulated gage, Type A, No. 3). 
ORNL-DWG 78-4453
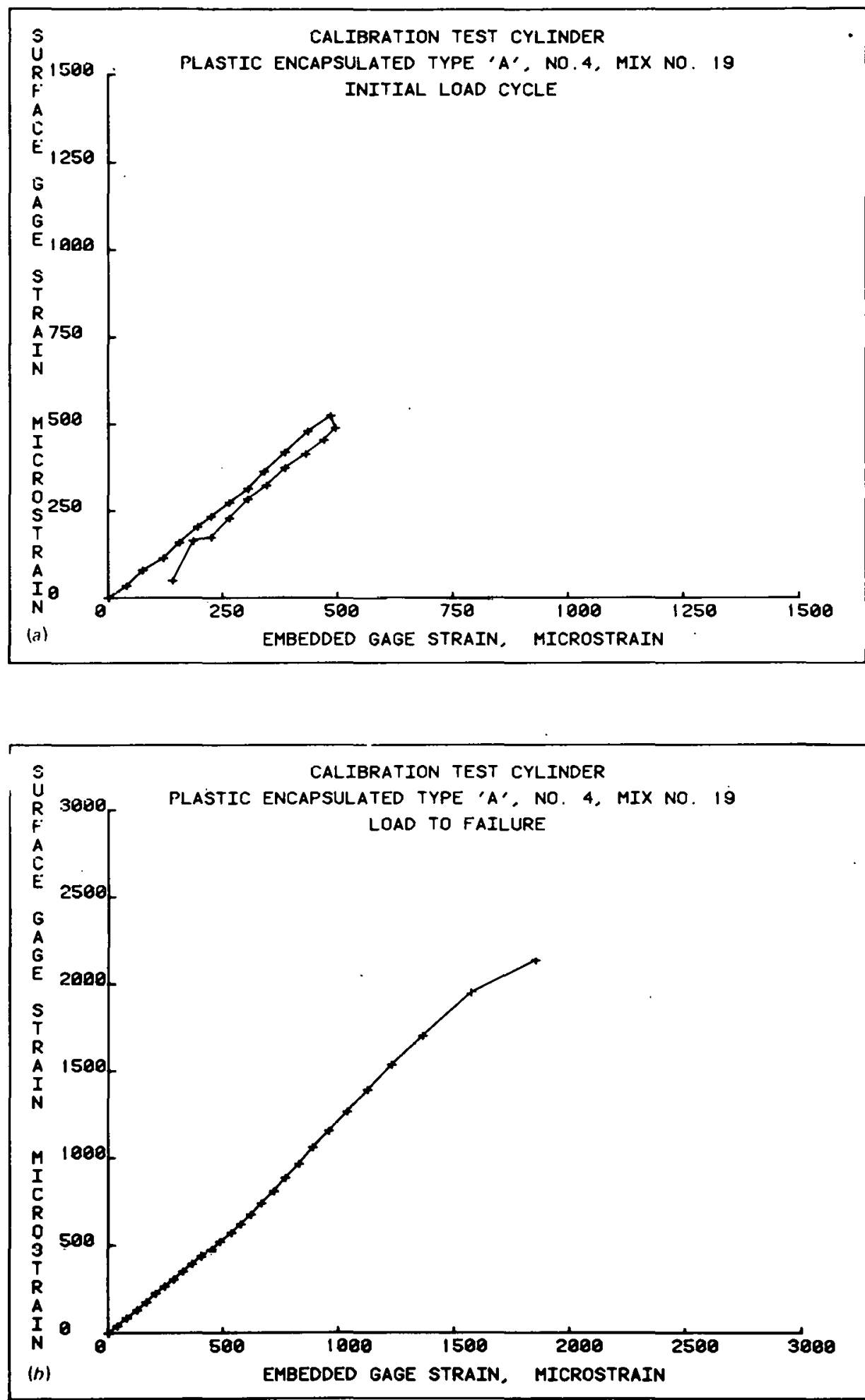

Fig. 11. Surface strain gage vs embedded gage output (plastic encapsulated gage, Type A, No. 4). 
ORNL-DWG 78-4454
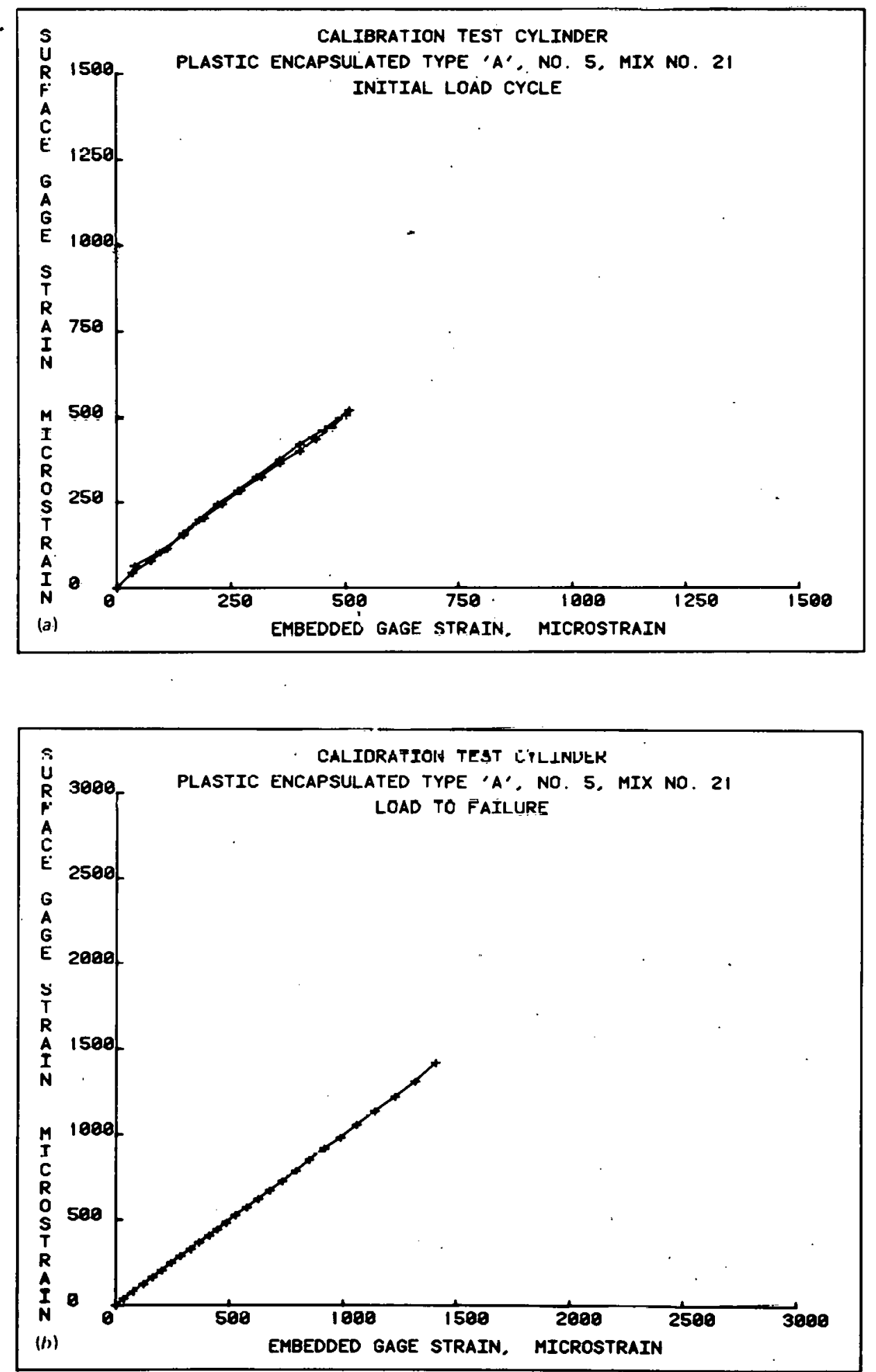

Fig. 12. Surface strain gage vs embedded gage output (plastic encapsulated gage, Type A, No. 5). 

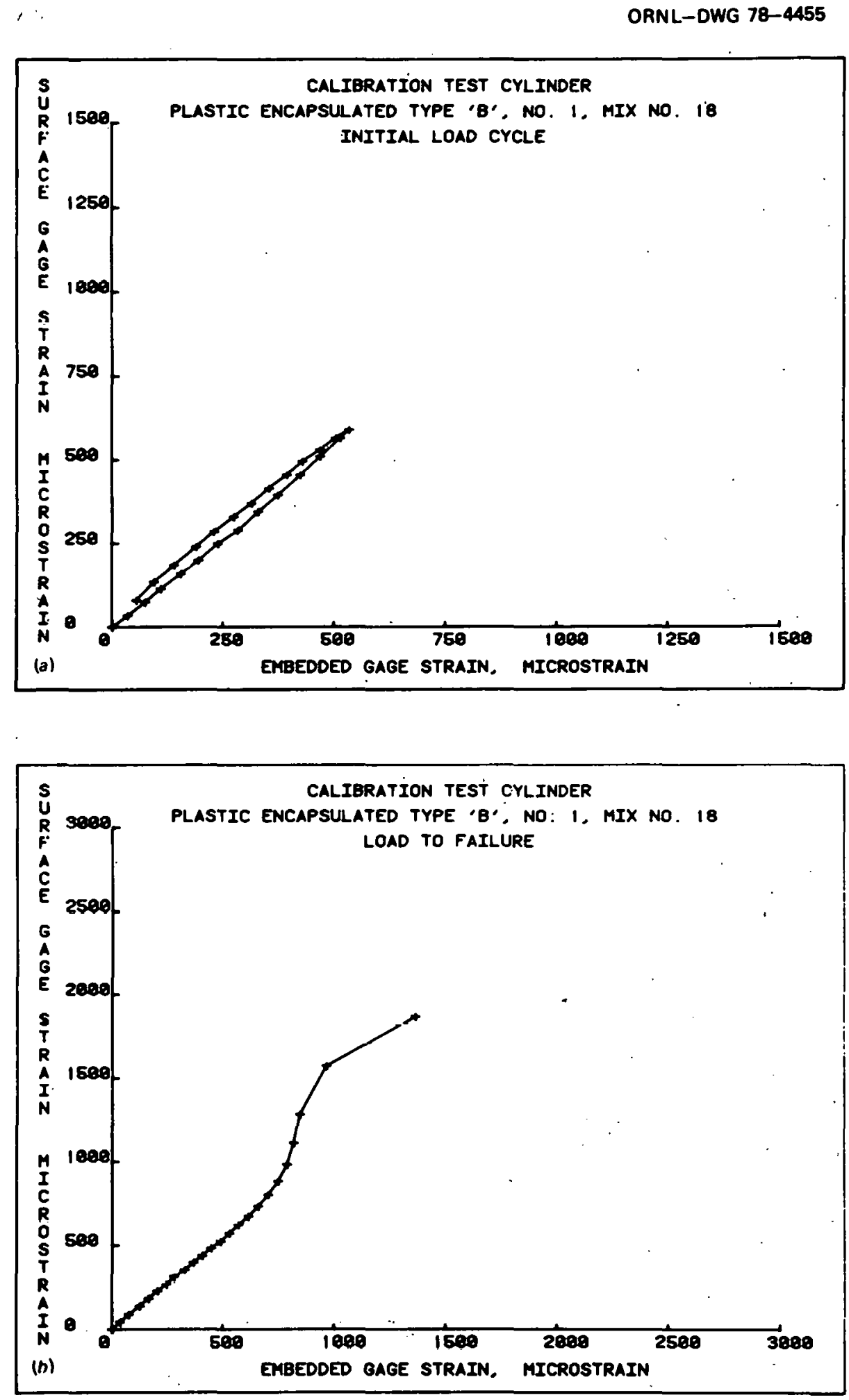

Fig. 13. Surface strain gage vs embedded gage output (plastic encapsulated gage, Type B, No. 1). 
ORNL-DWG 78-4456
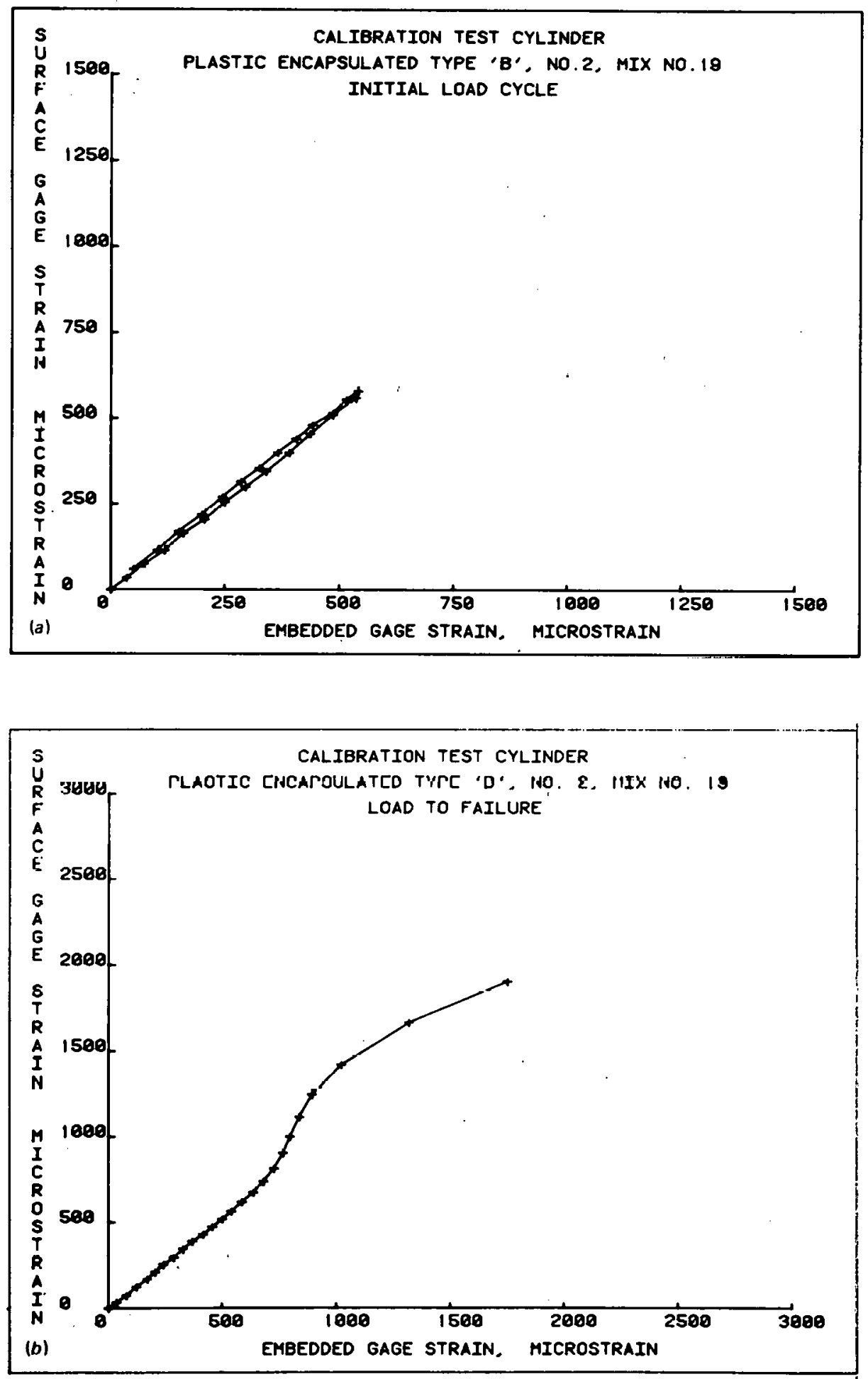

Fig. 14. Surface strain gage vs embedded gage output (plastic encapsulated gage, Type $B$, No. 2). 
ORNL-DWG 78-4457
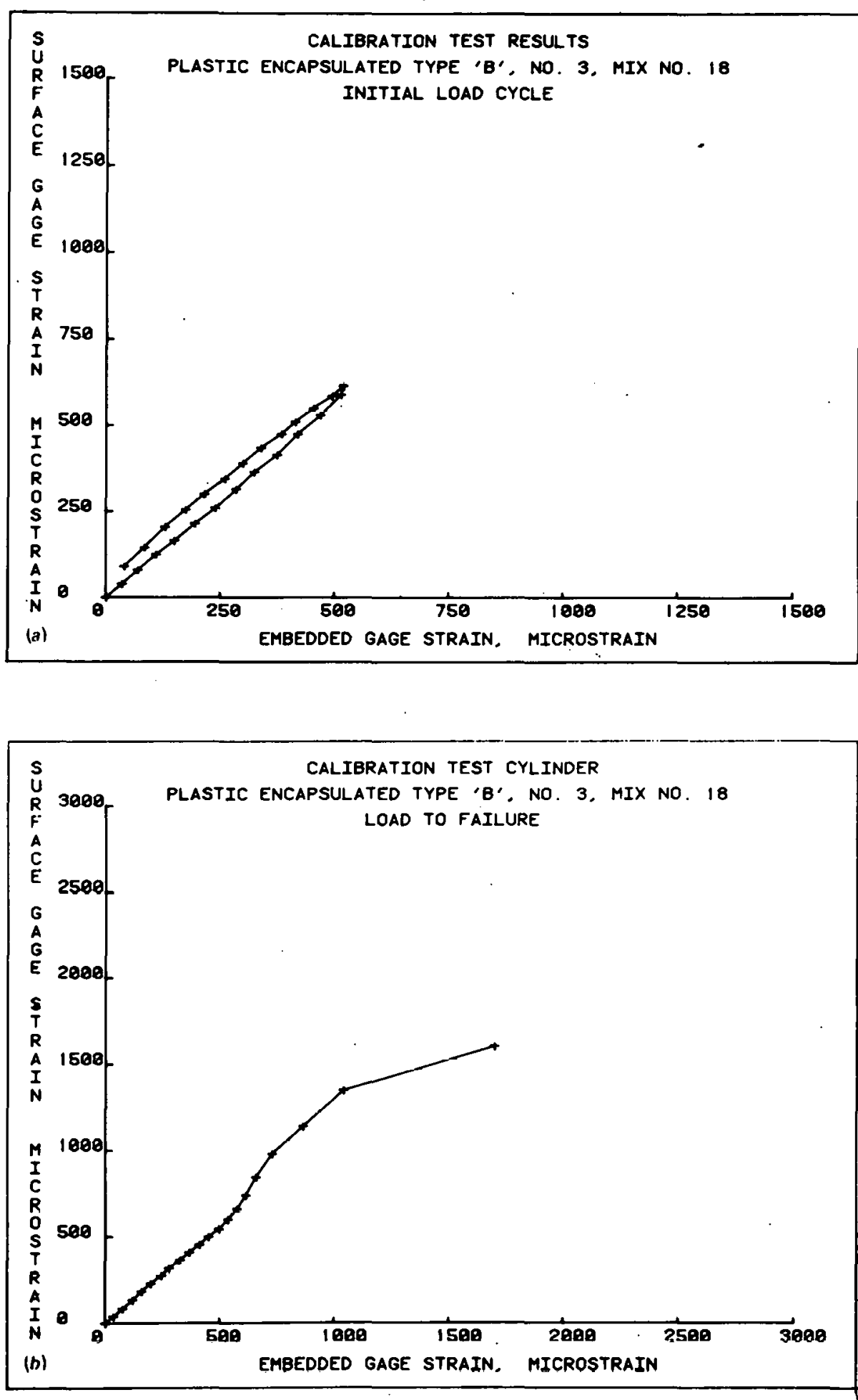

Fig. 15. Surface strain gage vs embedded gage output (plastic encapsulated gage, Турс B, No. 3). 
ORNL-OWG 78-4458
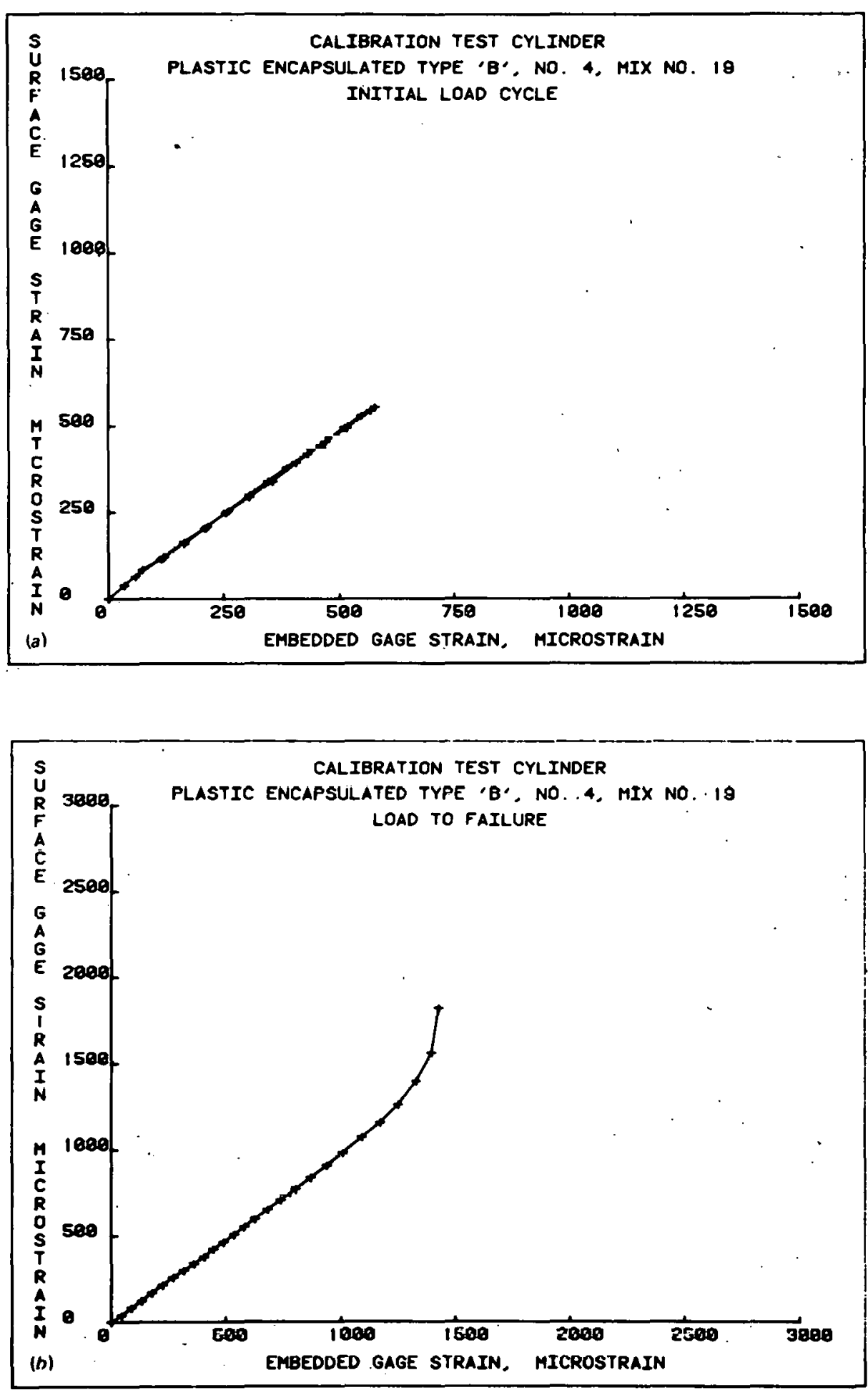

Fig. 16. Surface strain gage vs embedded gage output (plastic encapsulated gage, Type B, No. 4). 

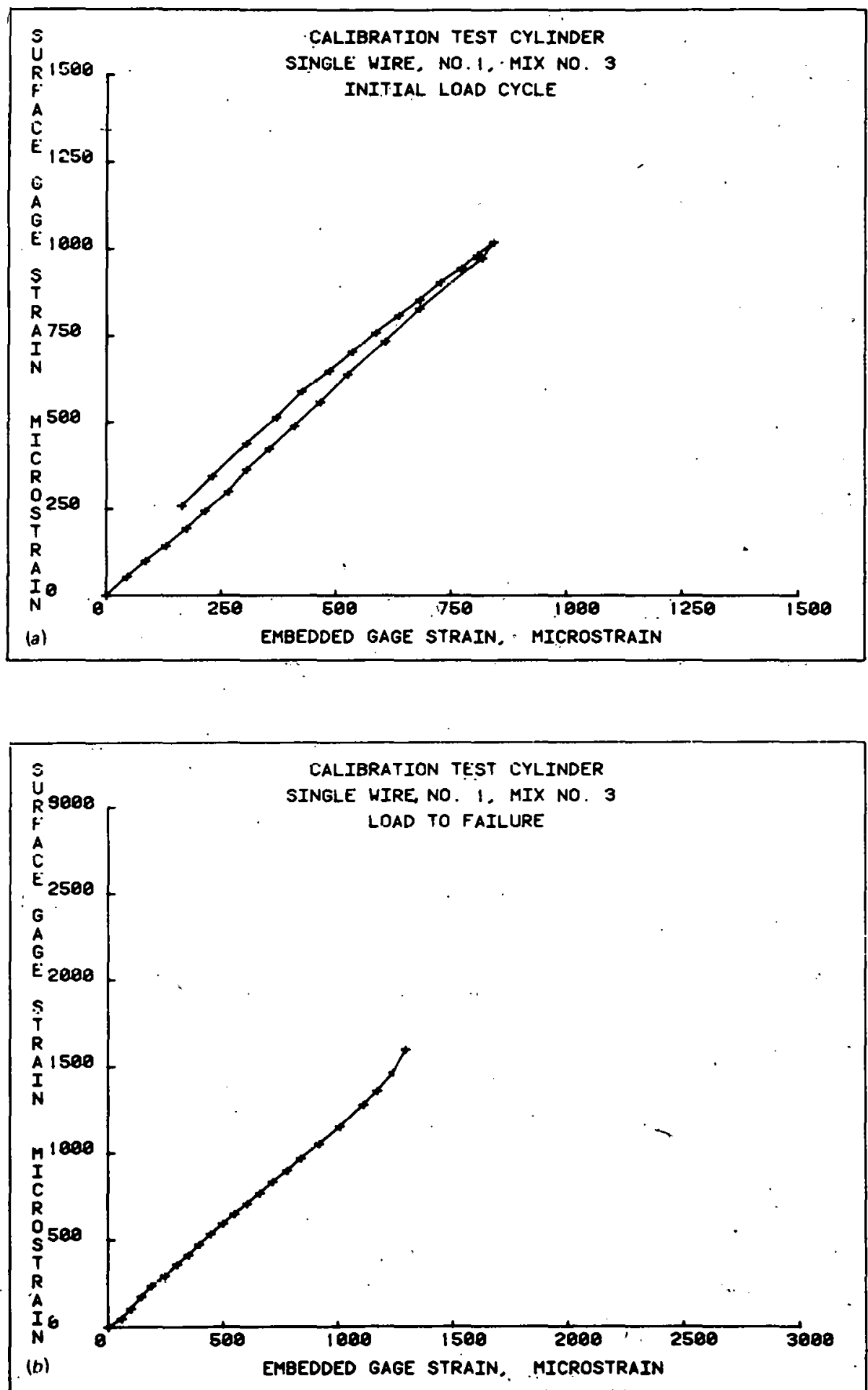

Fig. 17. Surface strain gage vs embedded gage output (single wire gage, No. 1). 
ORNL-DWG 78-4460
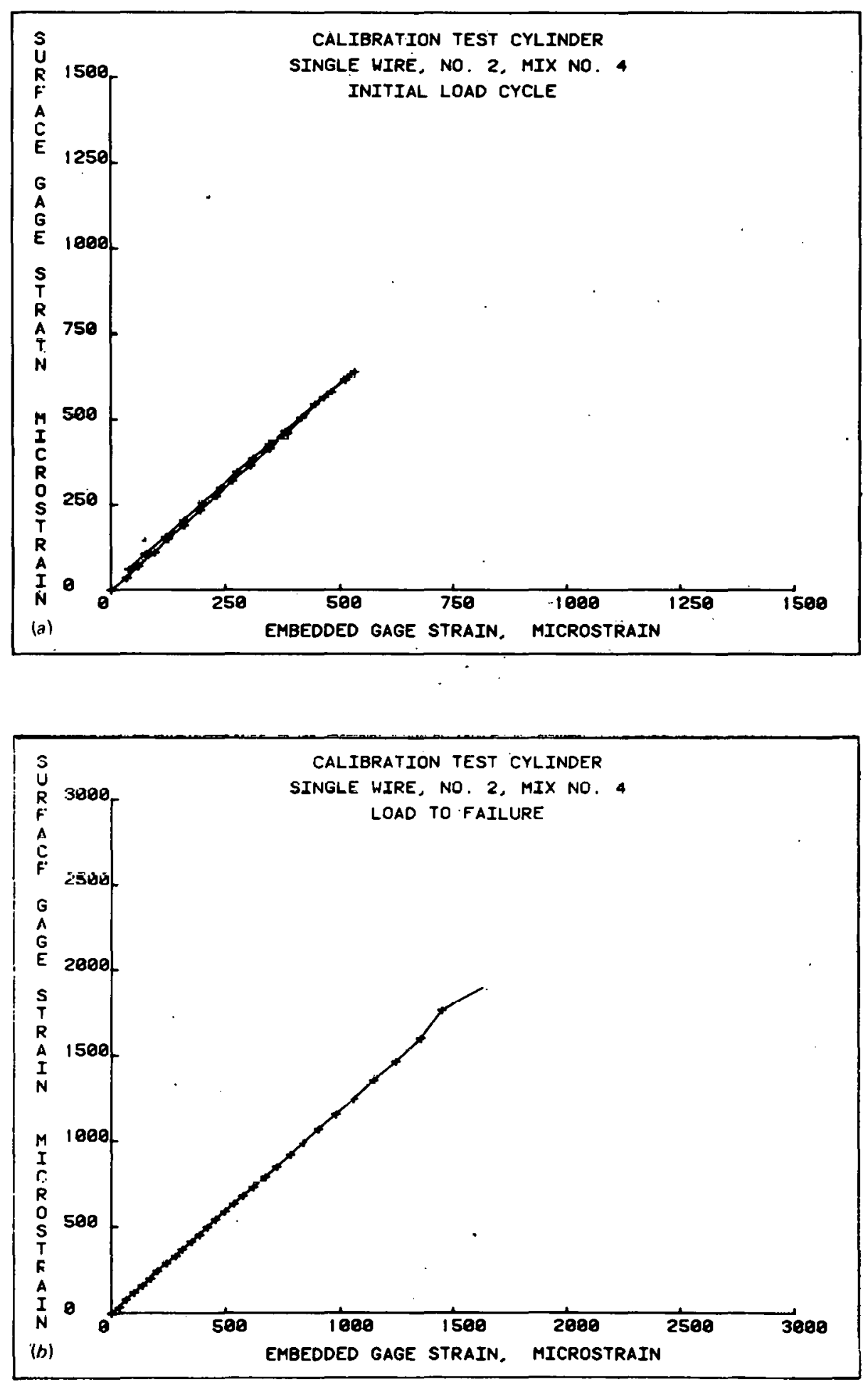

Fig. 18. Surface strain gage vs embedded gage output (single wire gage, No. 2). 

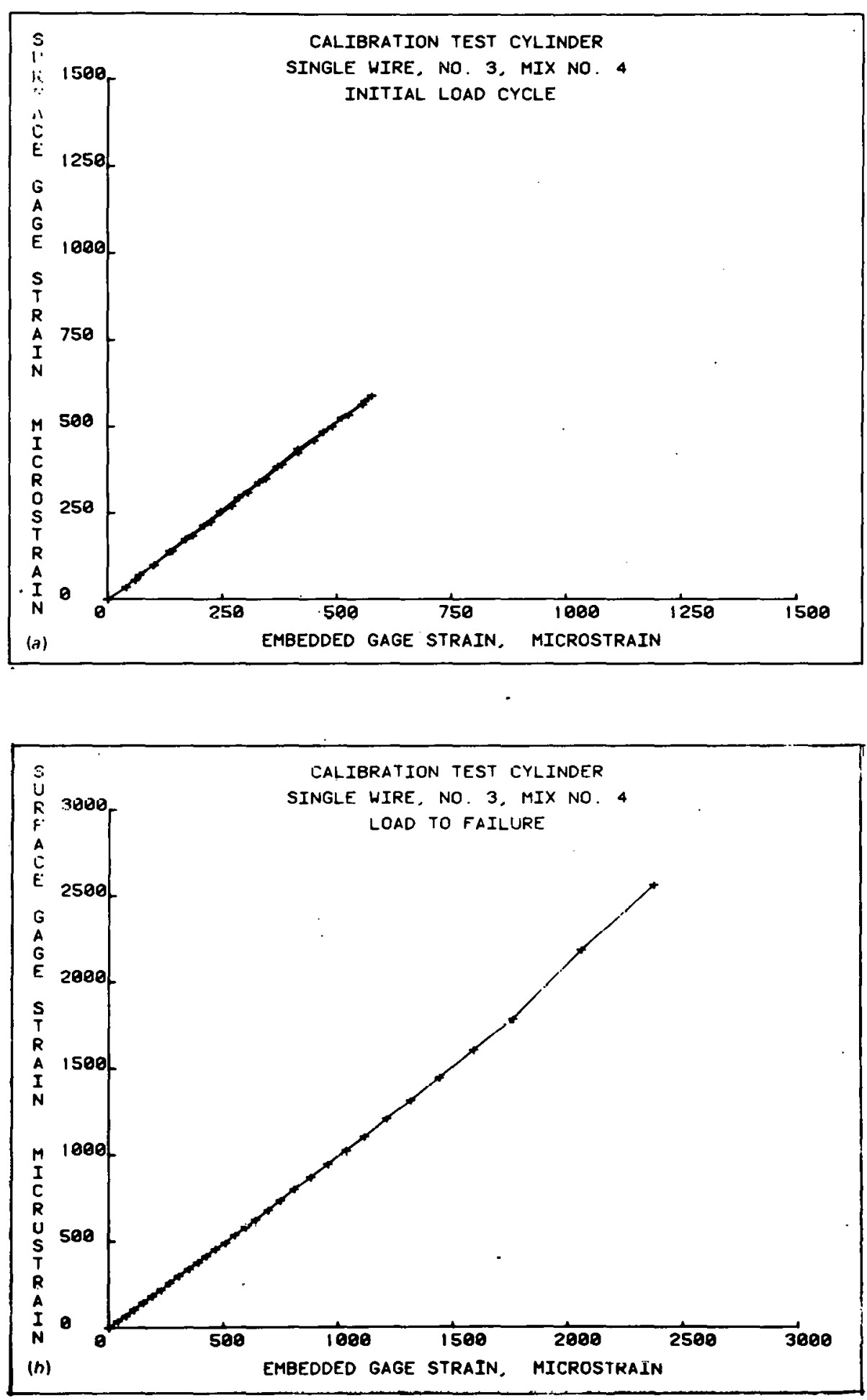

Fig. 19. Surface strain gage vs embedded gage output (single wire gage, No. 31. 

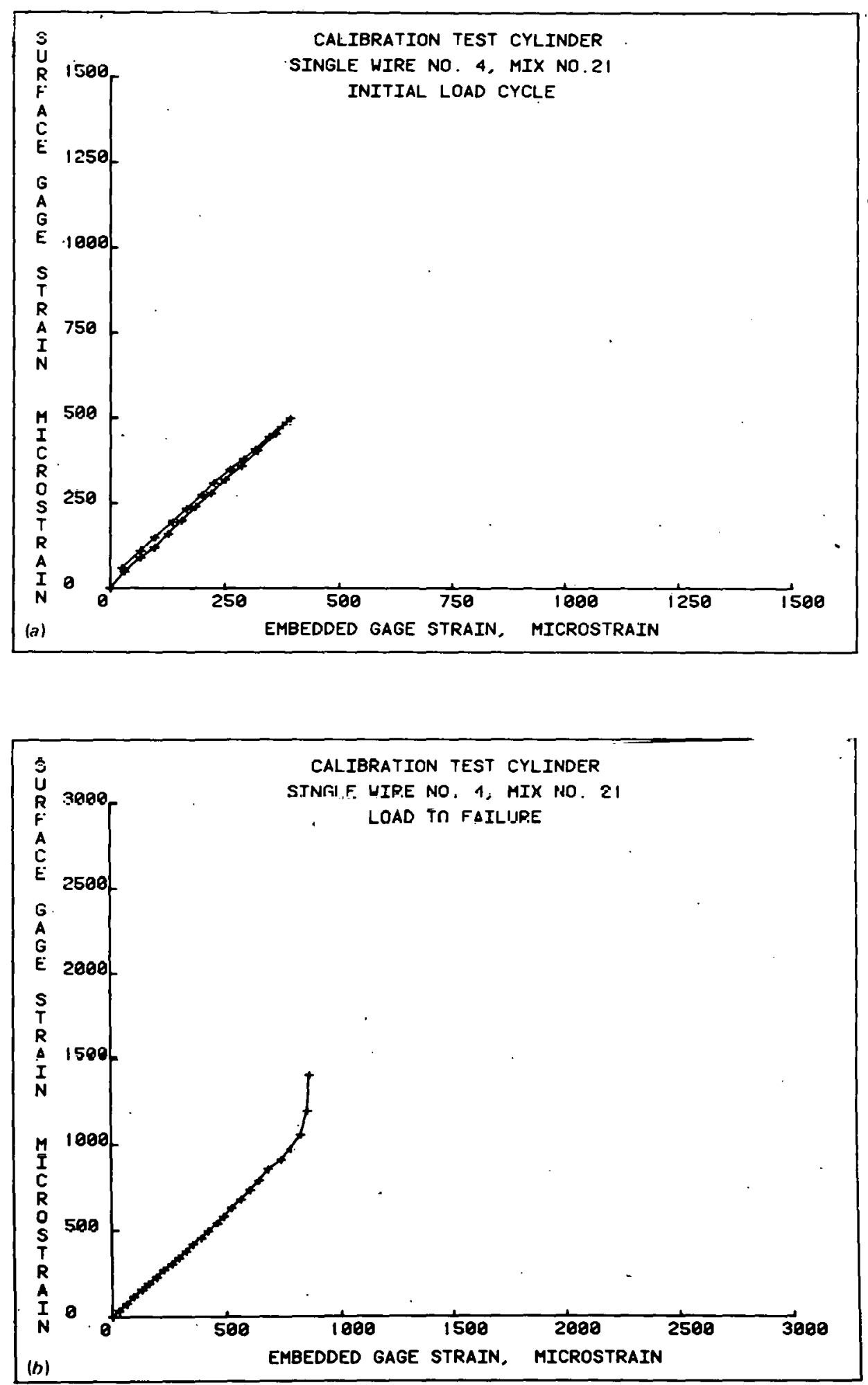

Fig. 20. Surface strain gage vs embedded gage output (single wire gage, No. 4). 
ORNL-DWG 78-4463
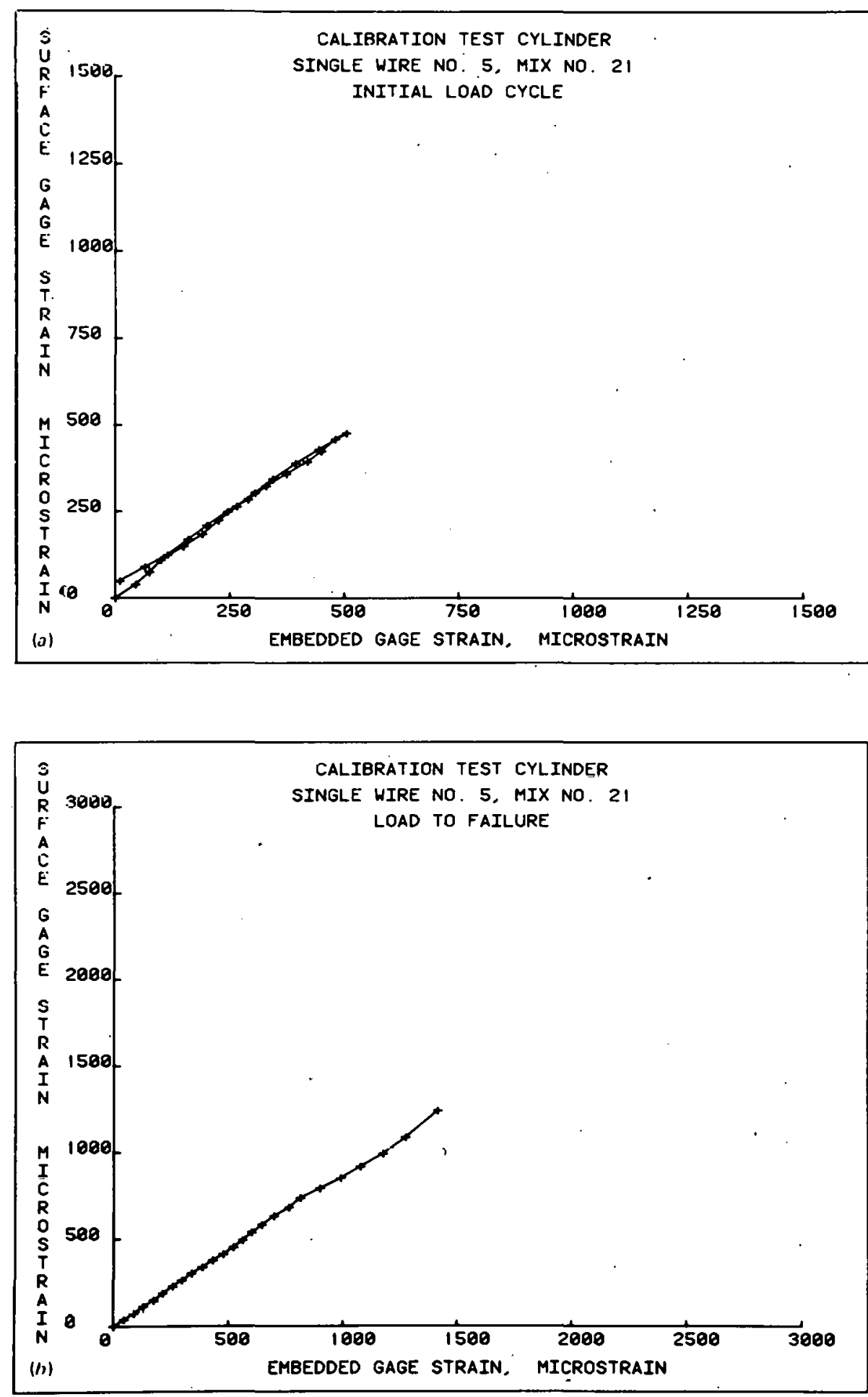

Fig. 21. Surface strain gage vs embedded gage output (single wire gage, No. 5). 
ORNL-DWG 78-4464
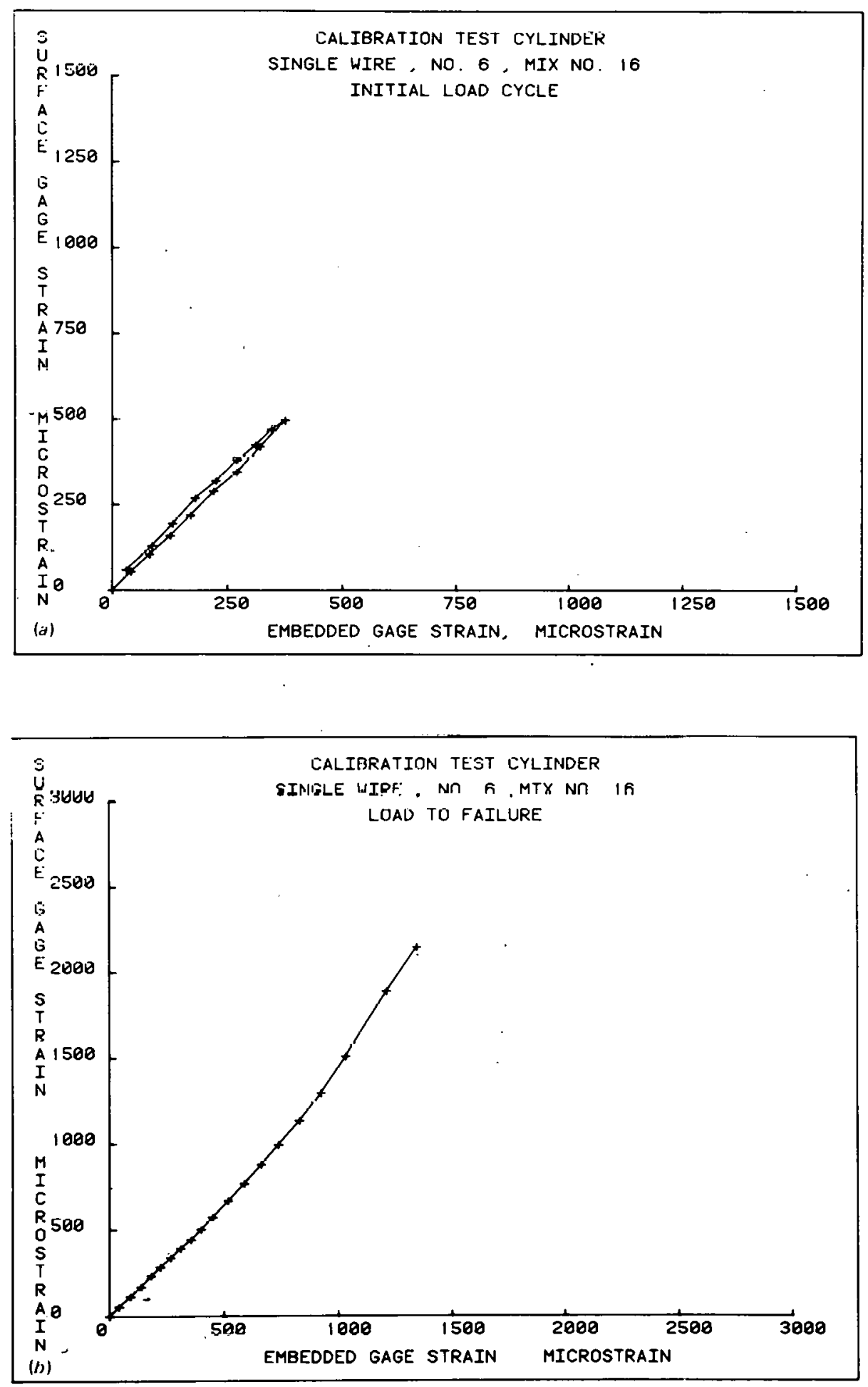

Fig. 22. Surface strain gage vs embedded gage output (single wire. gage, No. 6). 
ORNL-DWG 78-4465
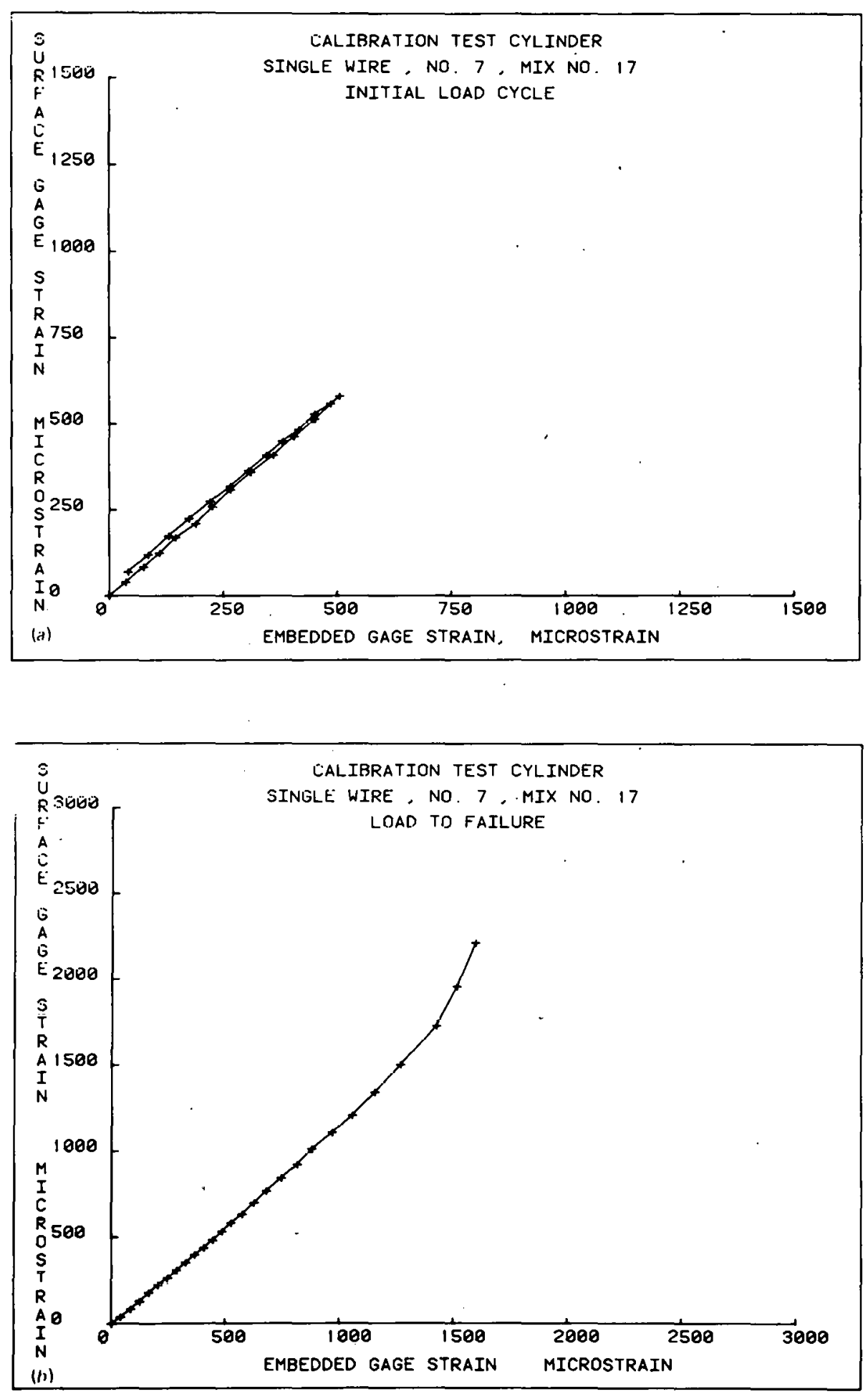

Fig. 23. Surface strain gage vs embedded gage output (single wire. gage, No. 7). 
ORNL-DWG 78-4466
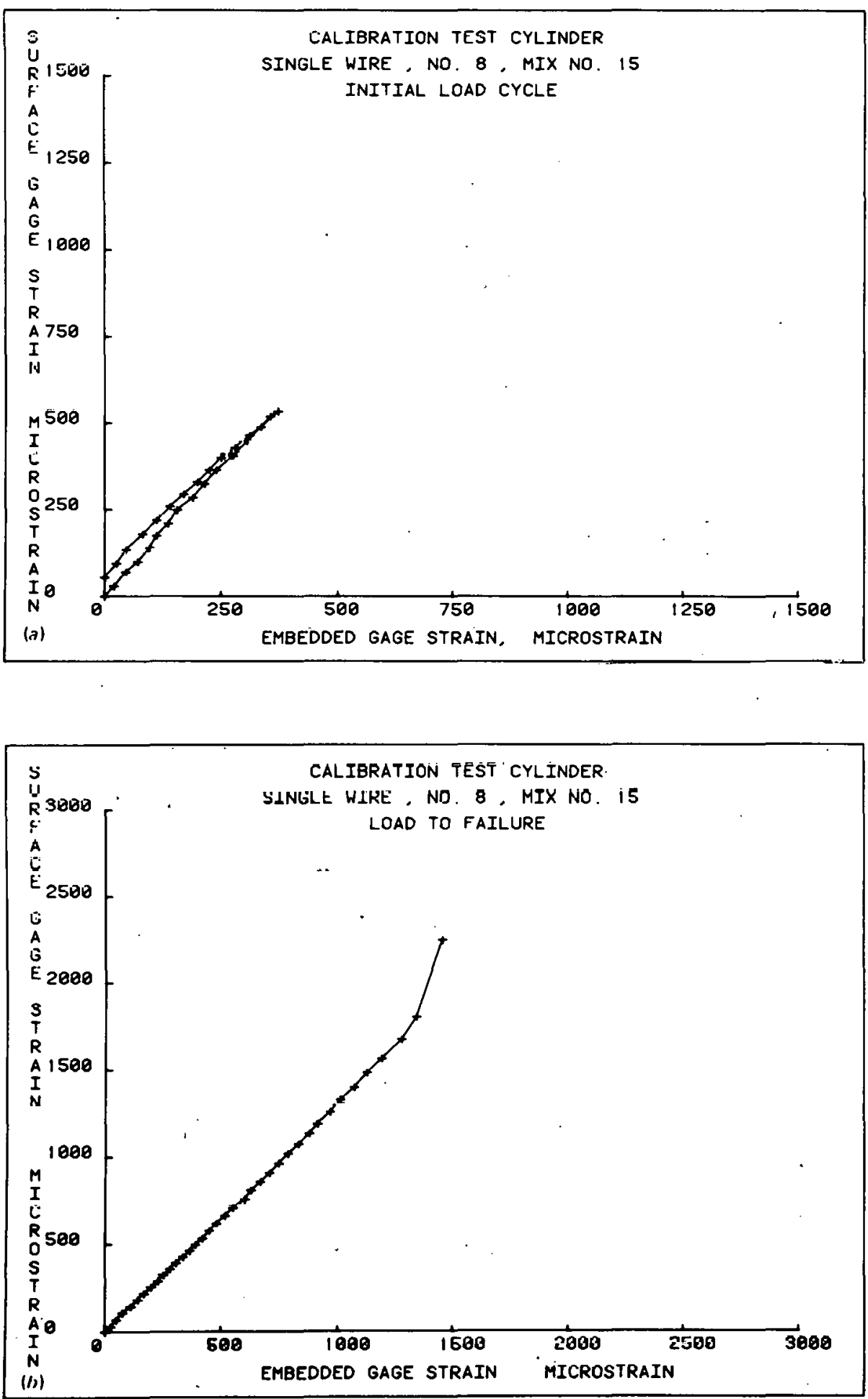

Fig. 24. Surface strain gage vs embedded gage output (single wire gage, No. 8). 
ORNL-DWG 78-4467
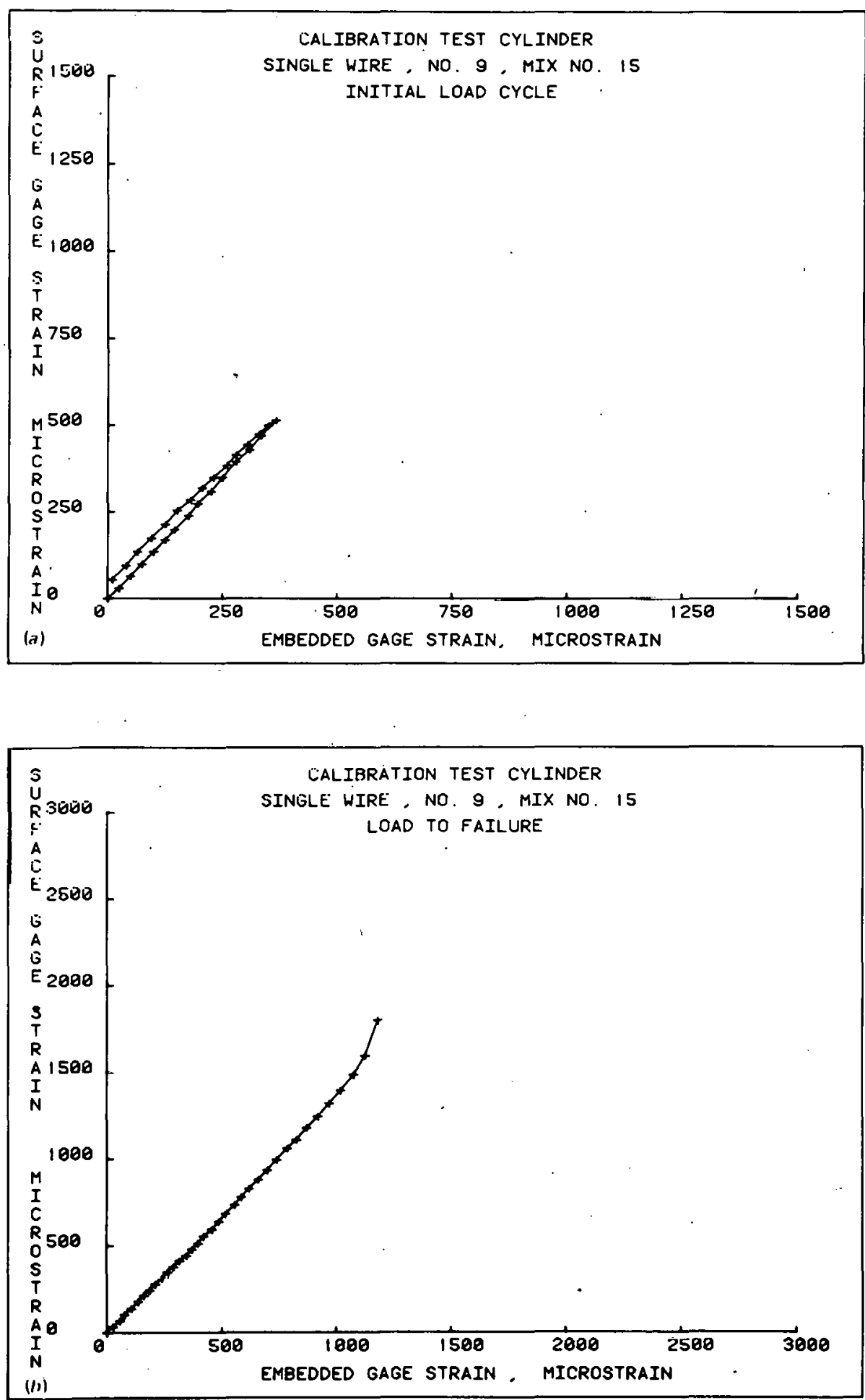

Fig. 25. Surface strain gage vs embedded gage output (single wire gage, No. 9). 
ORNL-DWG 78-4468
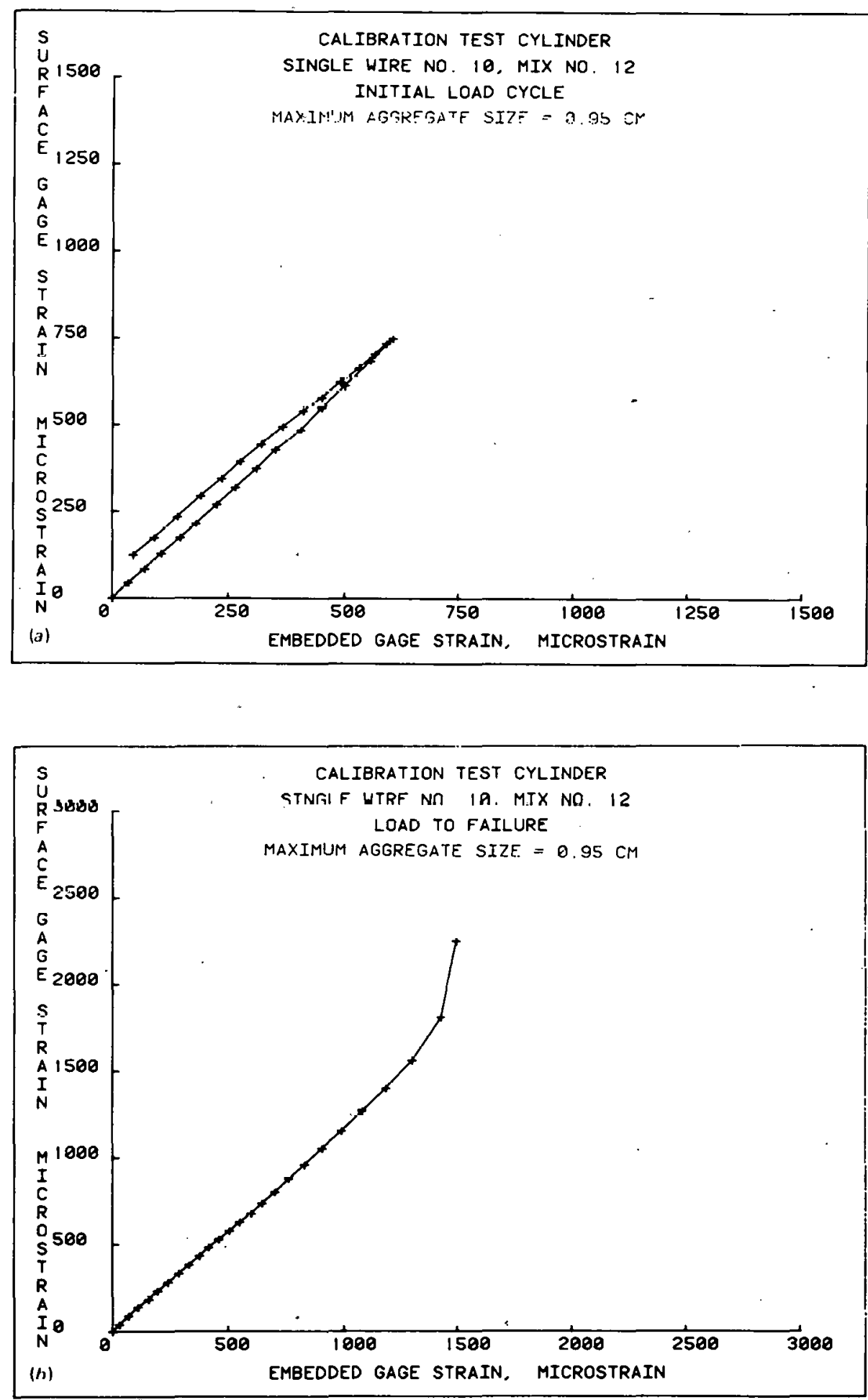

Fig. 26. Surface strain gage vs embedded gage output (single wire gage, No. 10). 
ORNL-DWG 78-4469
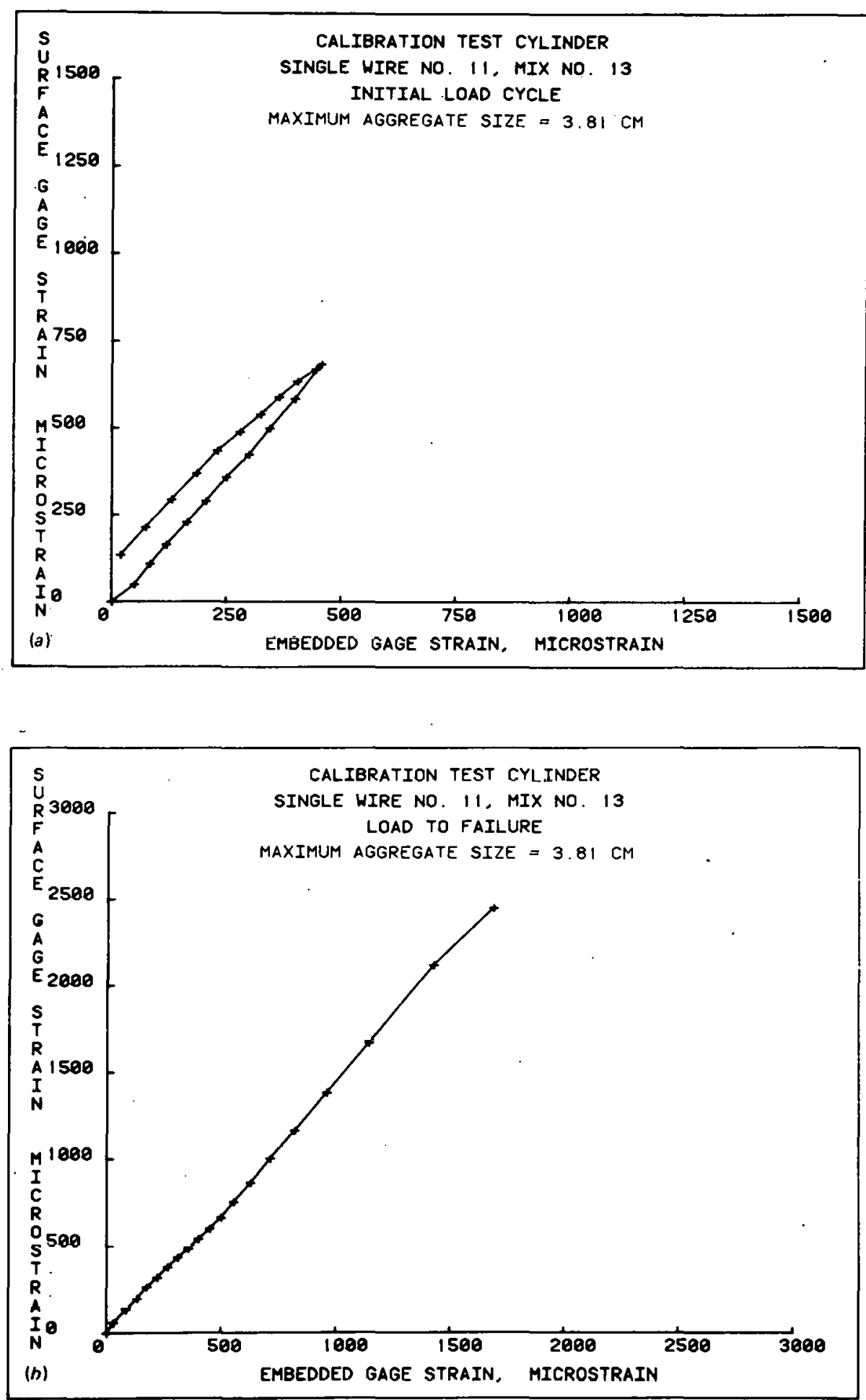

Fig. 27. Surface strain gage vs embedded gage output (single wire gage, No. 11). 
ORNL-DWG 78-4470
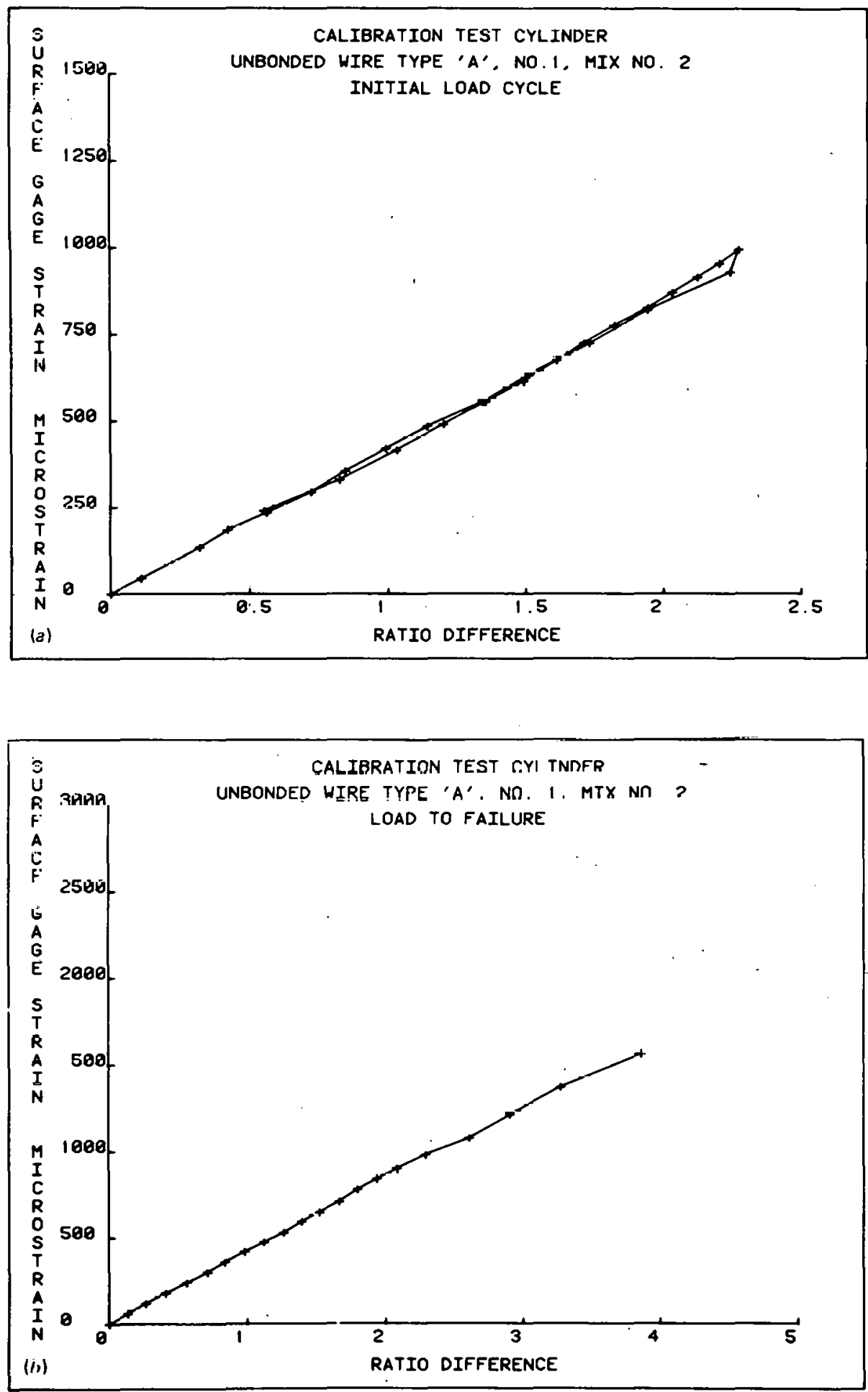

Fig. 28. Surface strain gage vs embedded gage output (unbonded wire gage, Type A, No. 1). 
ORNL-DWG 78-4471
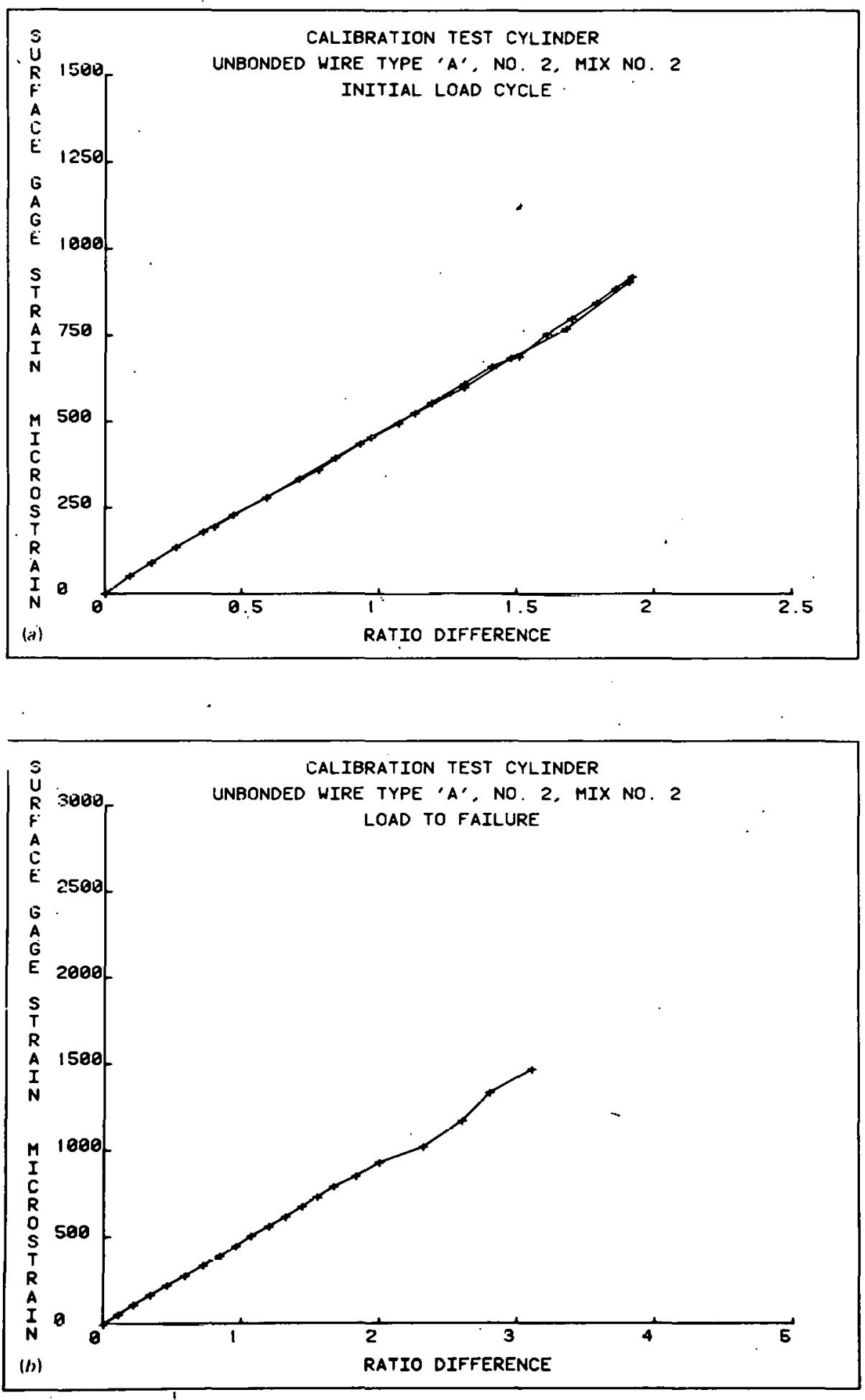

Fig. 29. Surface strain gage vs embedded gage output (unbonded wire gage, Type A, No. 2). 
ORNL-DWG 78-4472
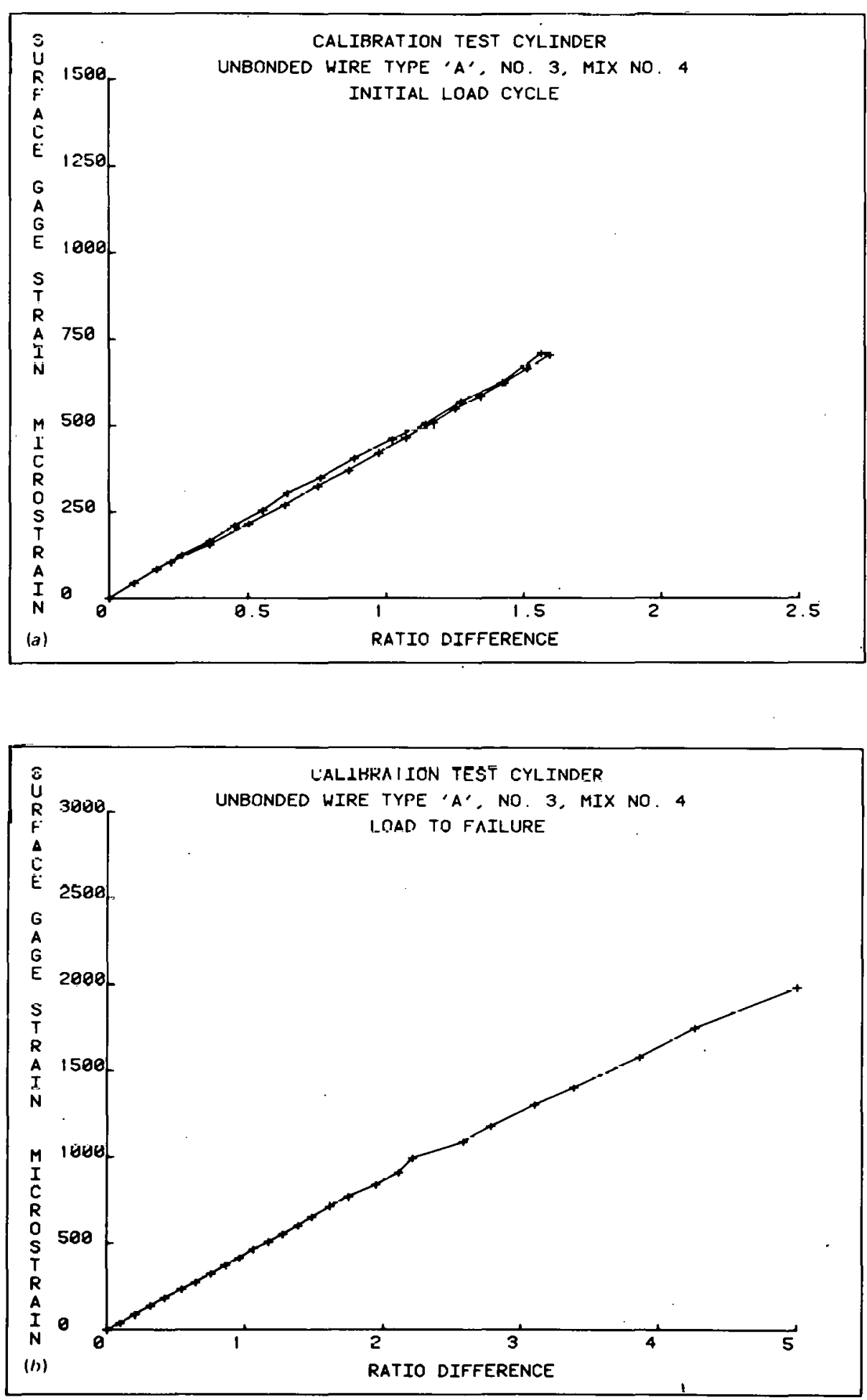

Fig. 30. Surface strain gage vs embedded gage output (unbonded wire gage, Type A, No. 3). 
ORNL-DWG 78-4473
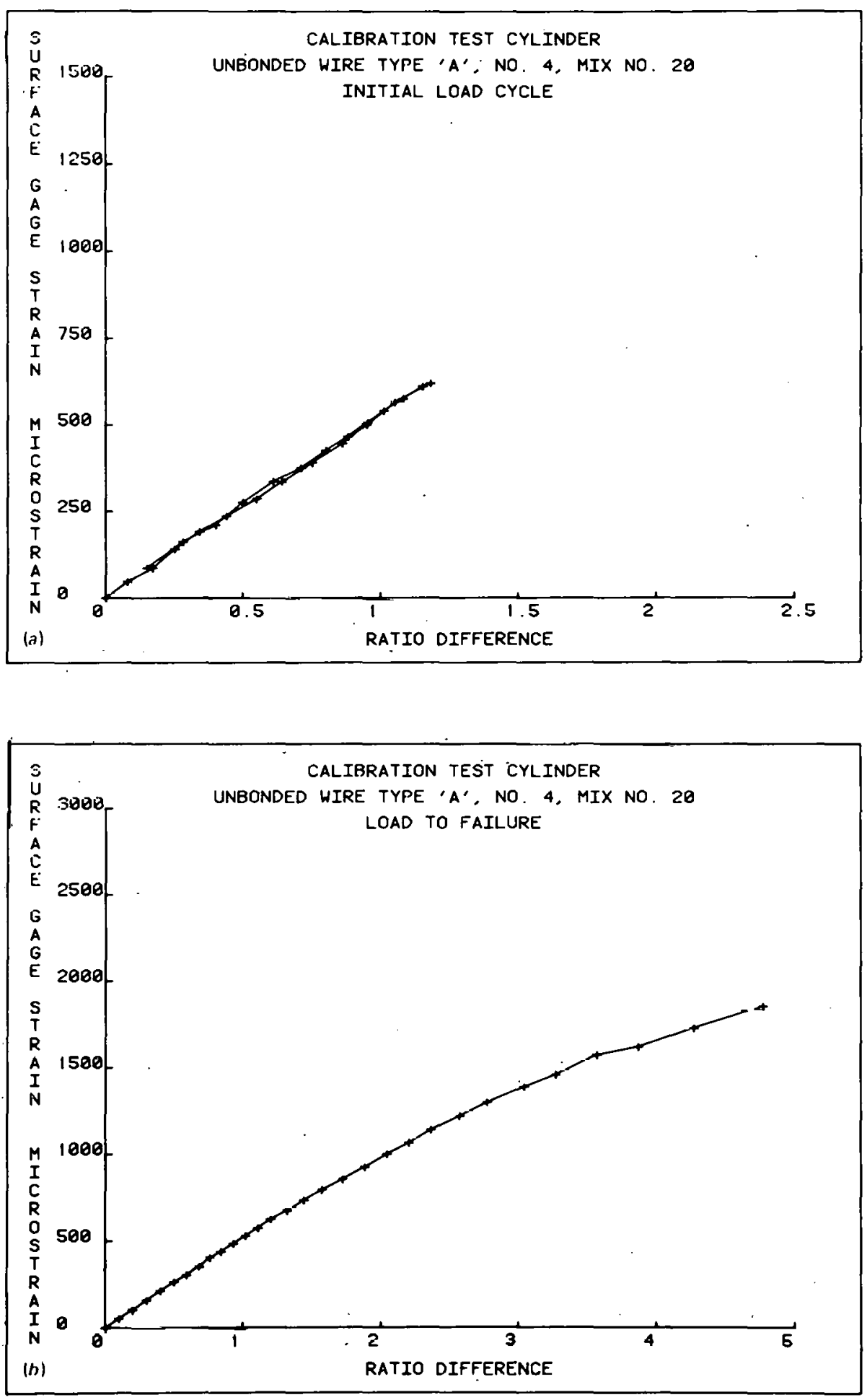

F1g. 31. Surface strain gage vs embedded gage output (unbonded wire gage, Type A, No. 4). 
ORNL-DWG 78-4474
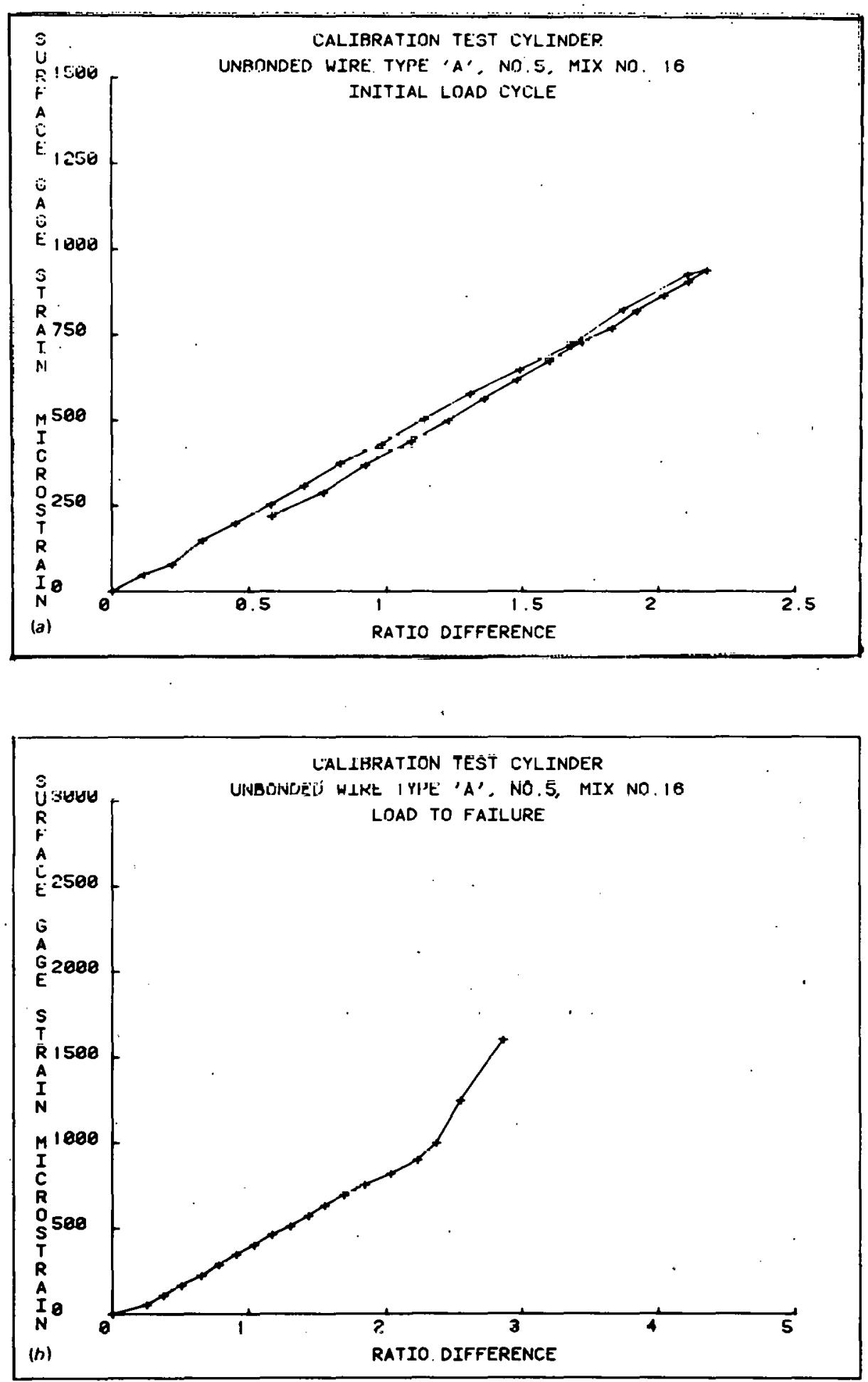

Fig. 32. Surface strain gage vs embedded gage output (unbonded wire gage, Type A, No. 5). 

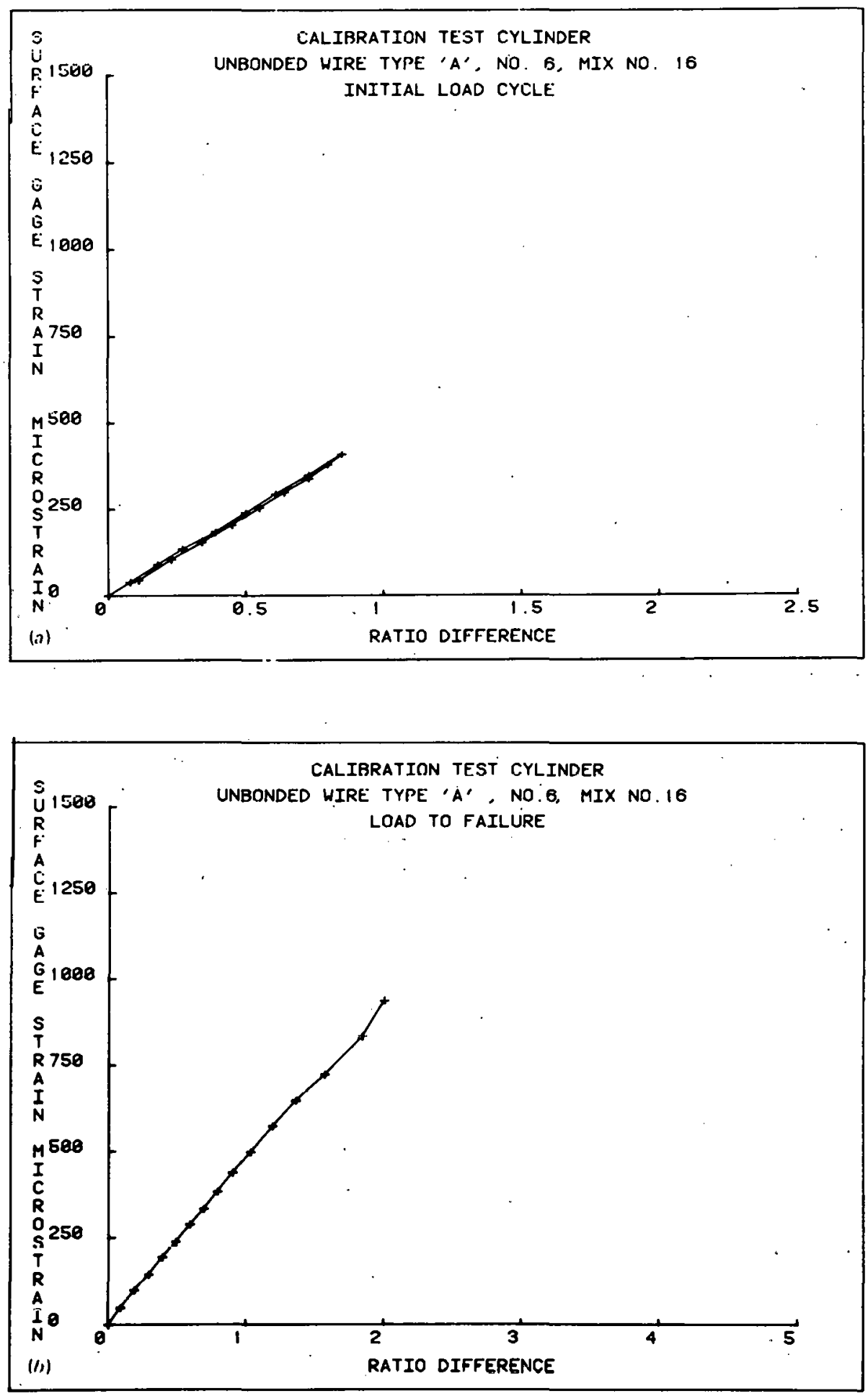

Fig. 33. Surface strain gage vs embedded gage output (unbonded wire gage, Type A, No. 6). 

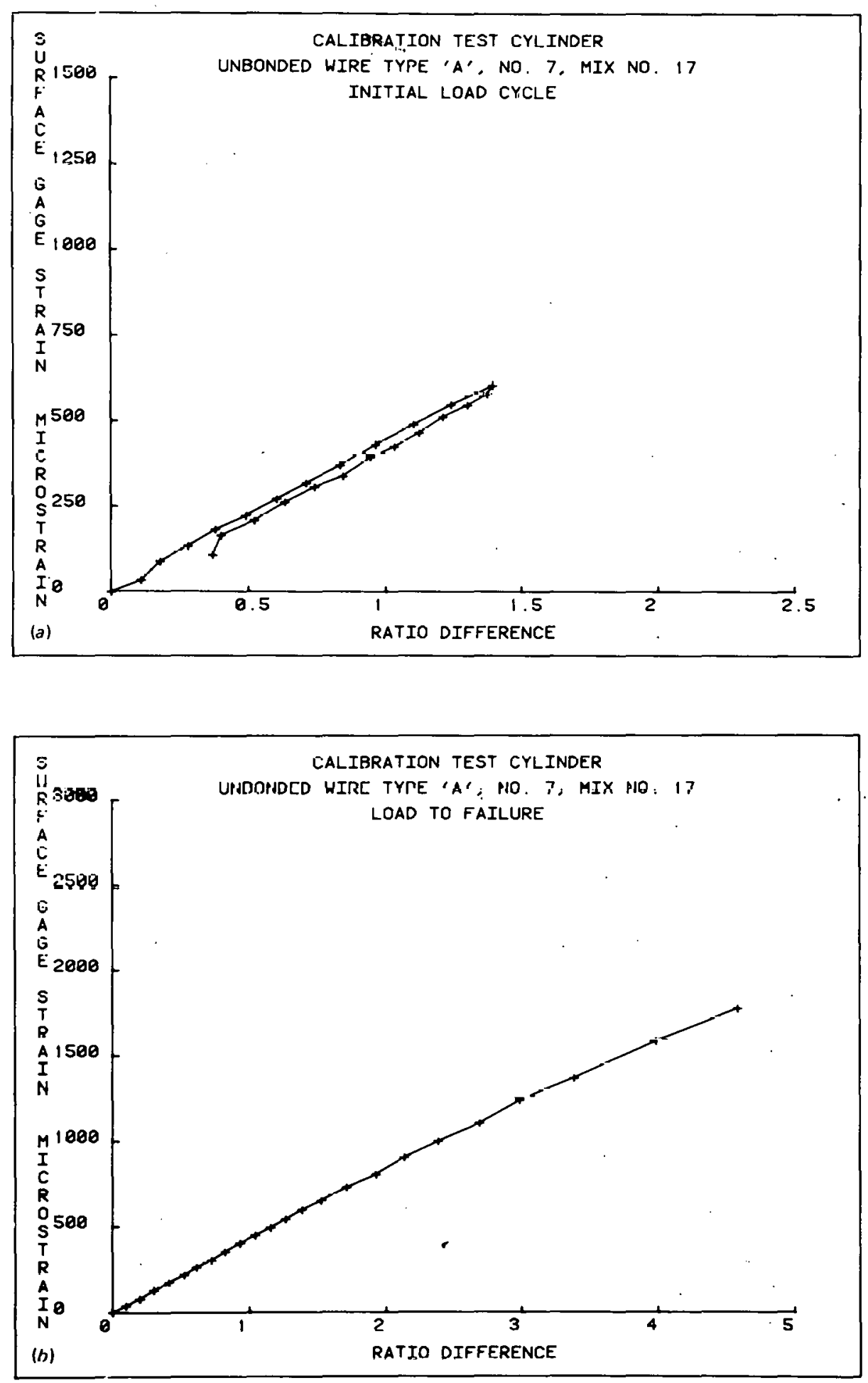

Fig. 34. Surface strain gage vs embedded gage output (unbonded wire gage, Type A, No. 7). 
ORNL-DWG 78-4477
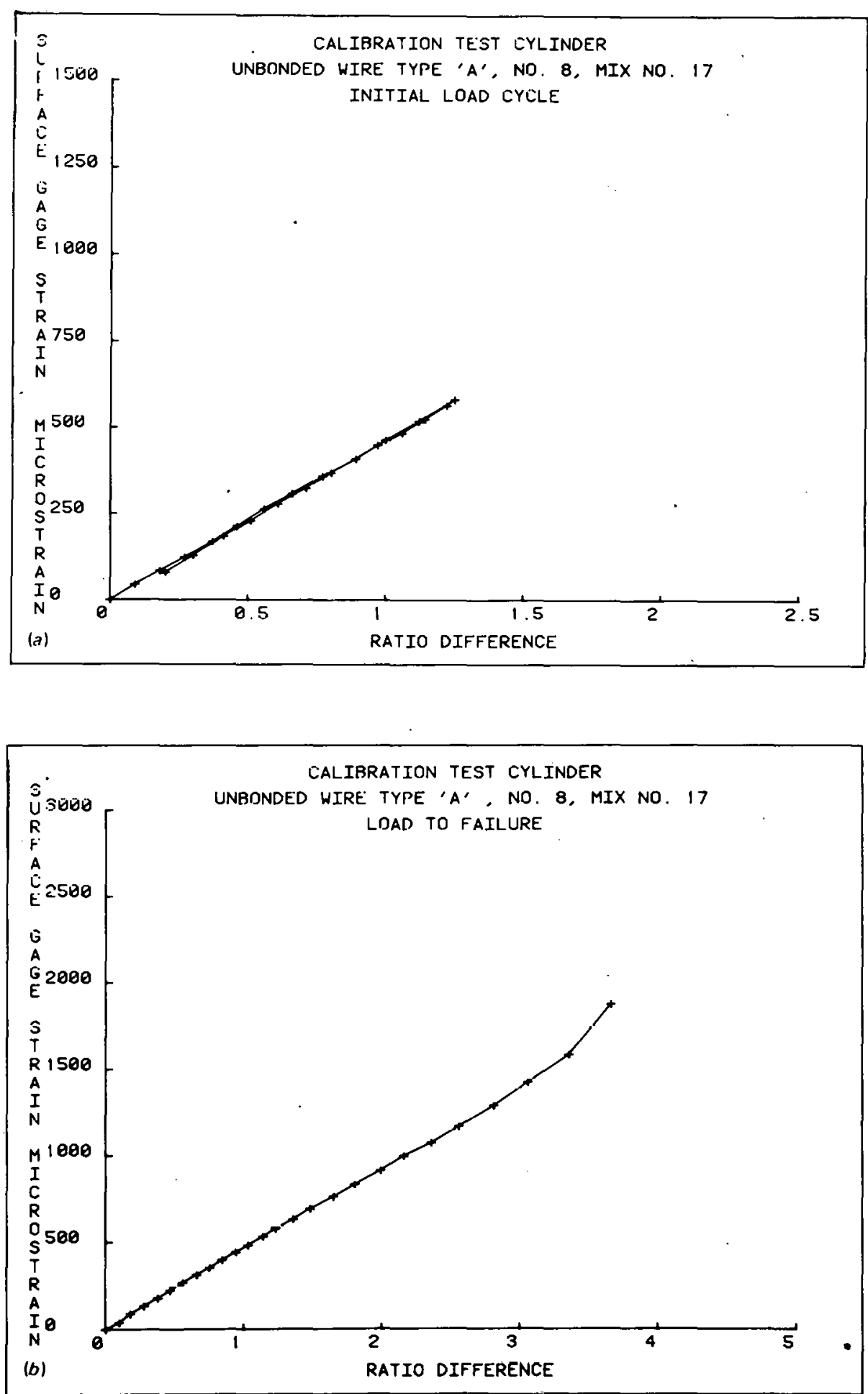

Fig. 35. Surface strain gage vs embedded gage output (unbonded wire gage, Type A, No. 8). 
ORNL-DWG 78-4478
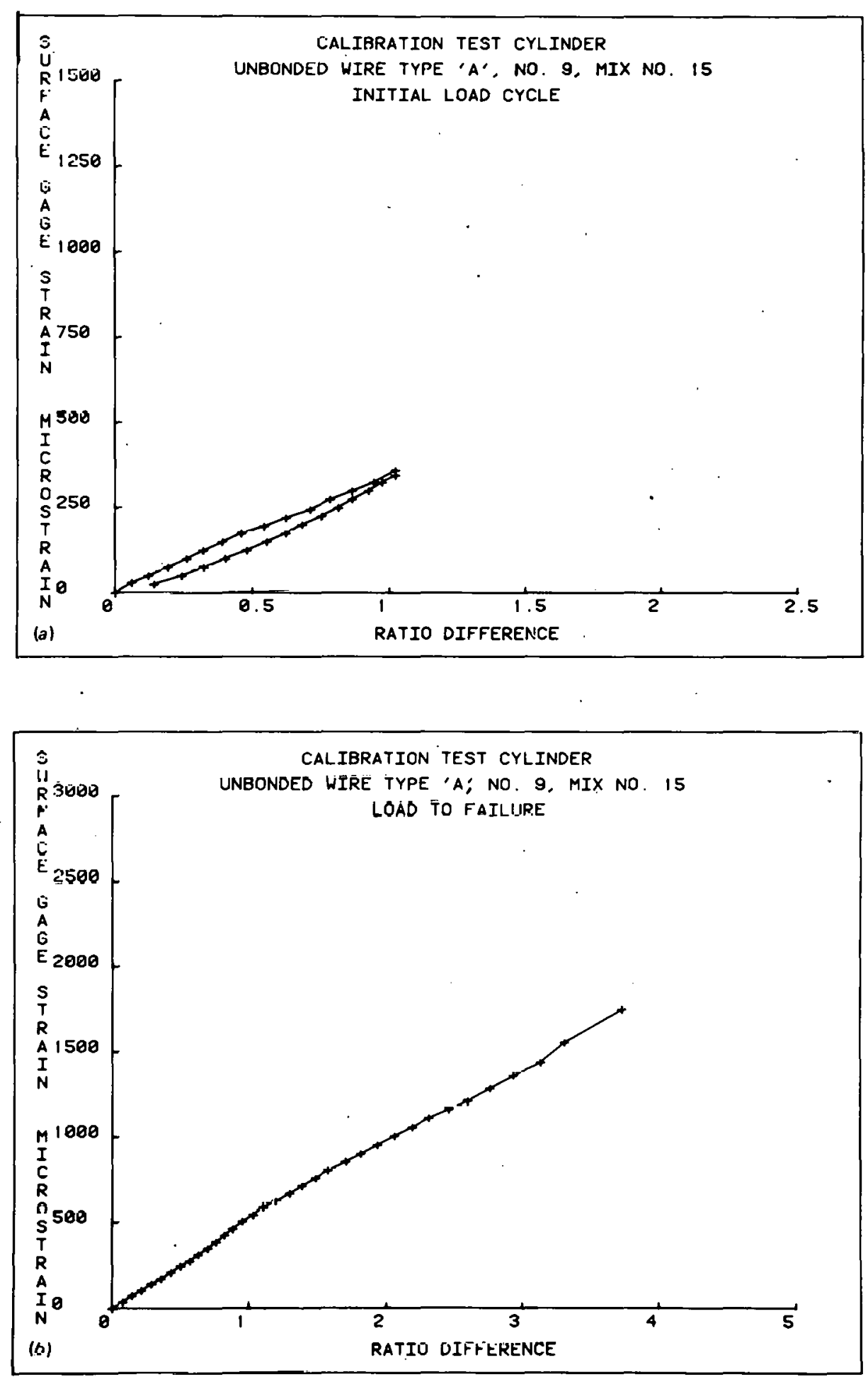

Fig. 36. Surface strain gage vs embedded gage output (unbonded wire gage, Type A, No. 9). 

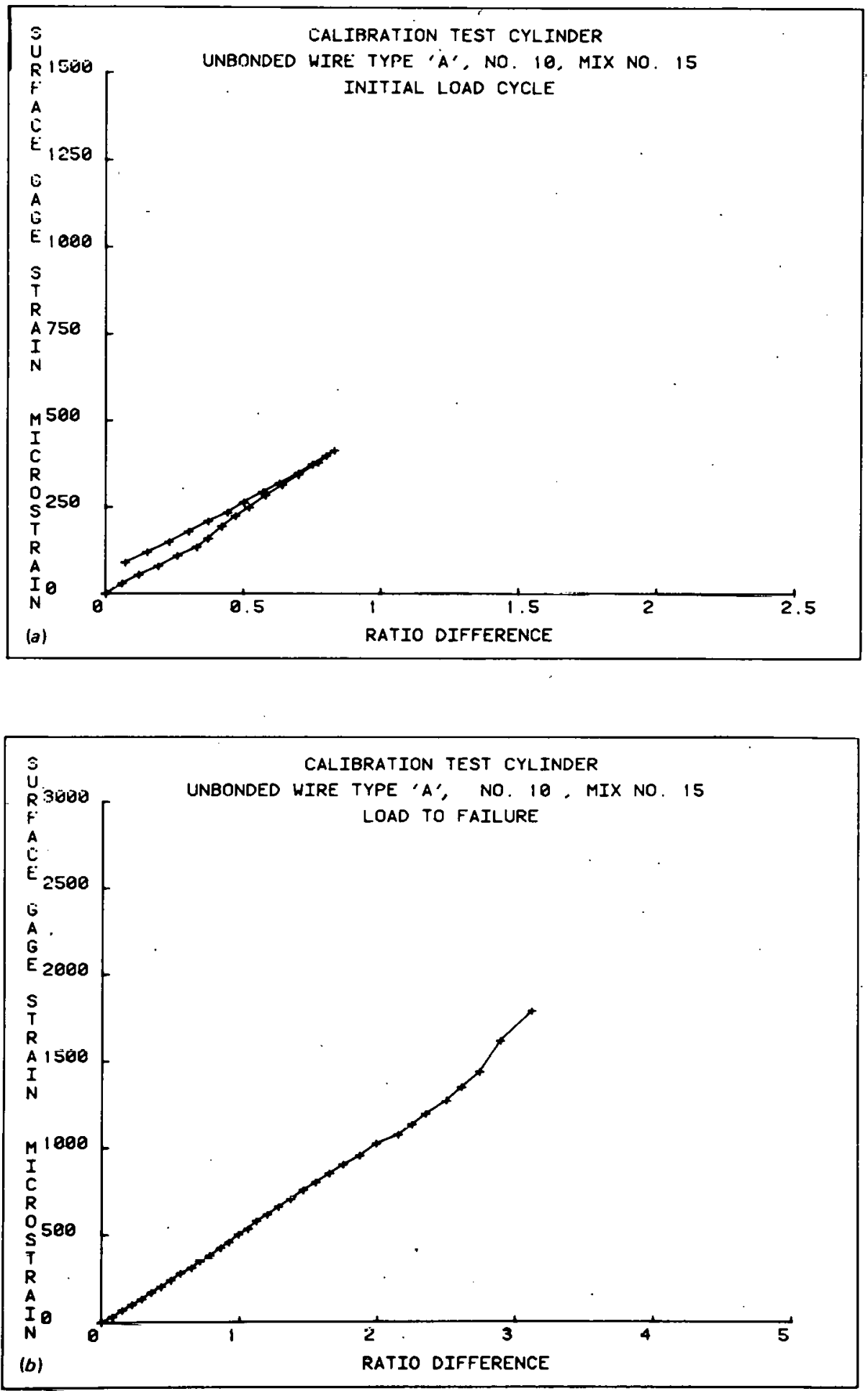

Fig. 37. Surface strain gage vs embedded gage output (unbonded wire gage, Type A, No. 10). 
ORNL-DWG 78-4480

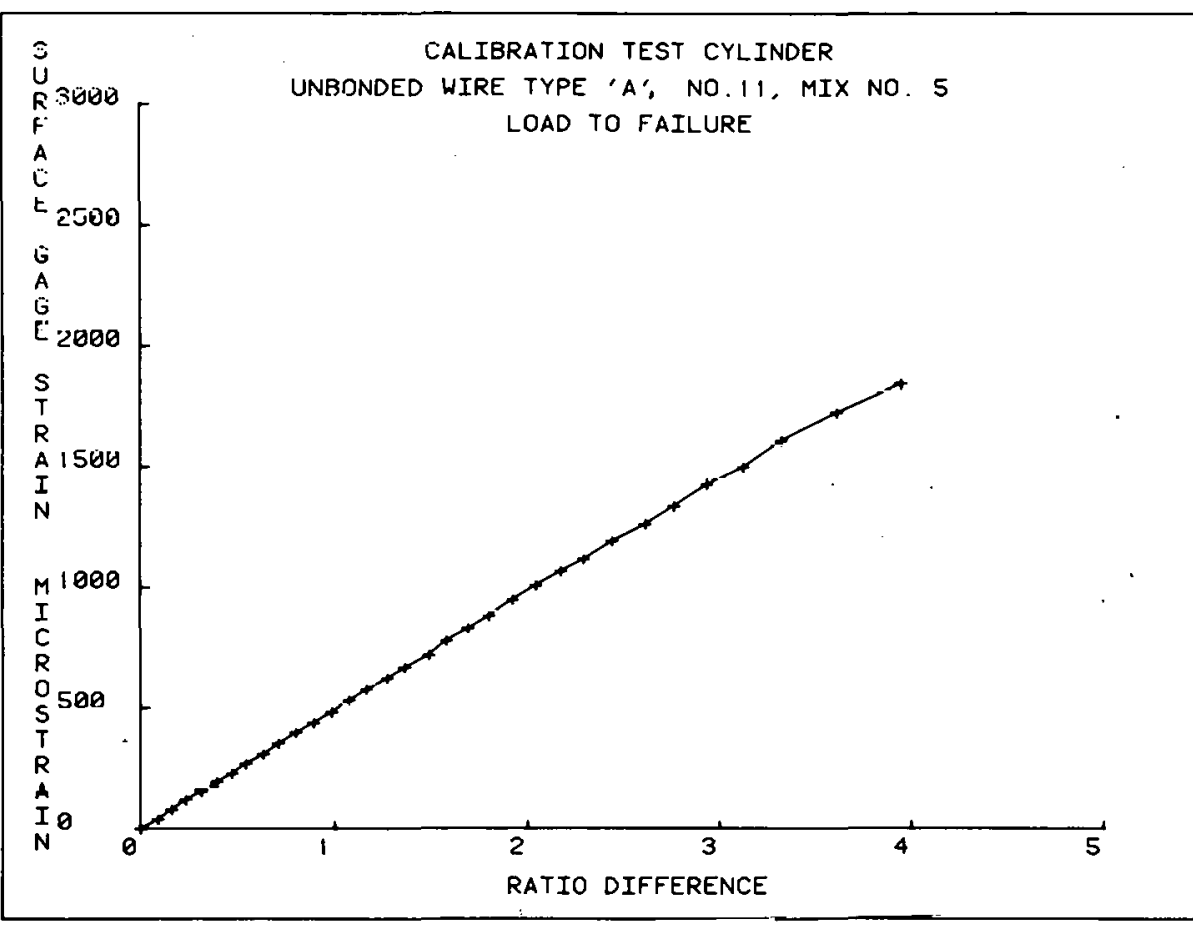

Fig. 38. Surface strain gage vs embedded gage output (unbonded wire gage, Type A, No. 11). 
ORNL-DWG 78-4481

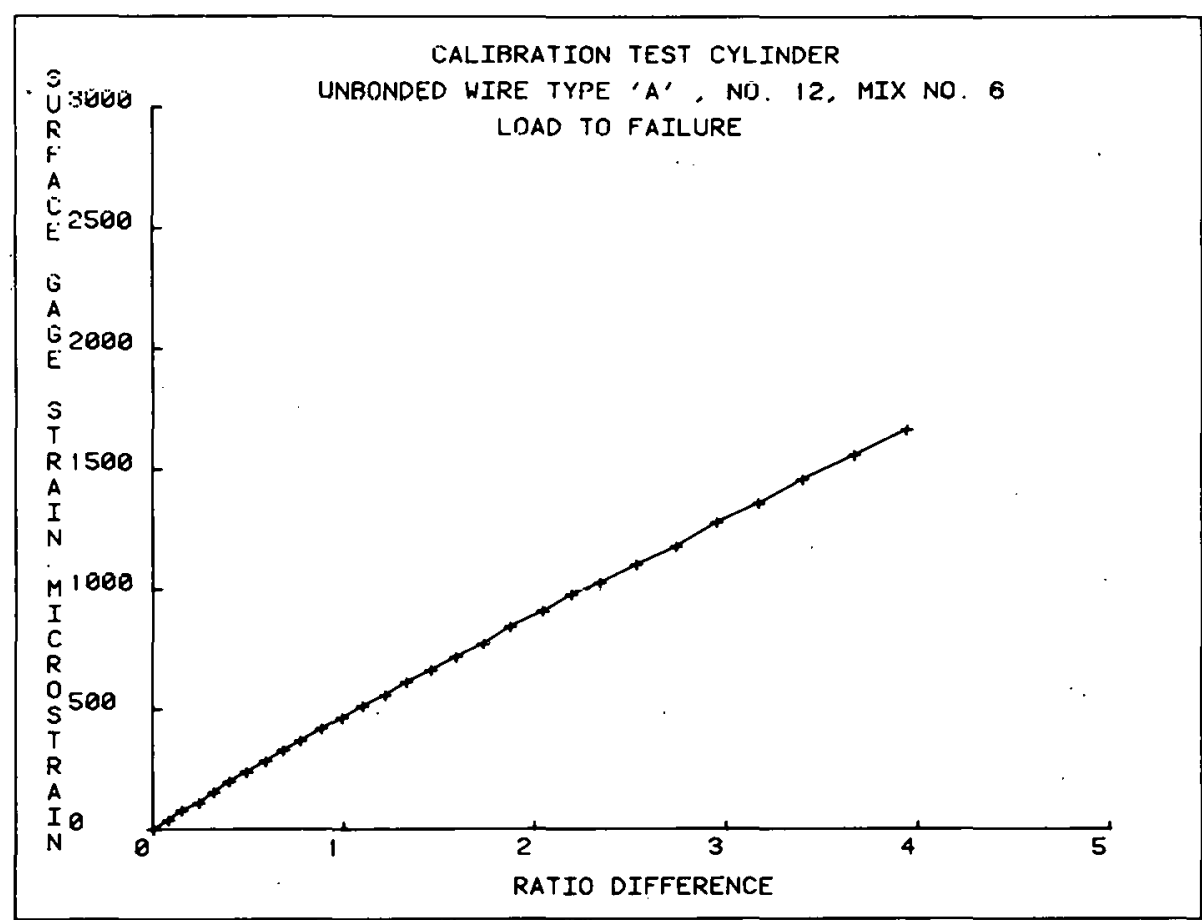

Fig. 39. Surface strain gage vs embedded gage output (unbonded wire gage, Type A, No. 12). 
ORNL-DWG 78-4482

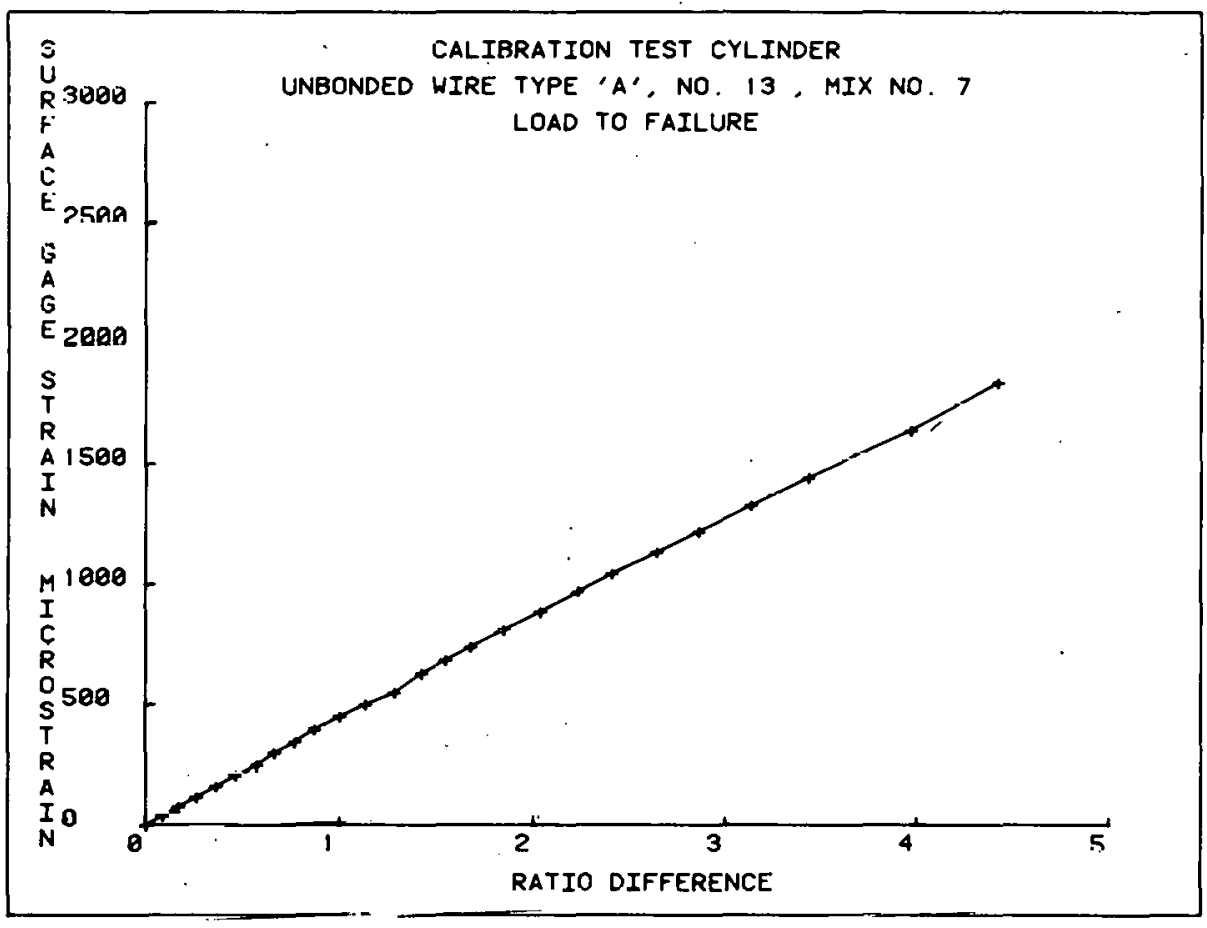

Fig. 40. Surface strain gage vs embedded gage output (unbonded wire gage, Type A, No. 13). 
ORNL-DWG 78-4483
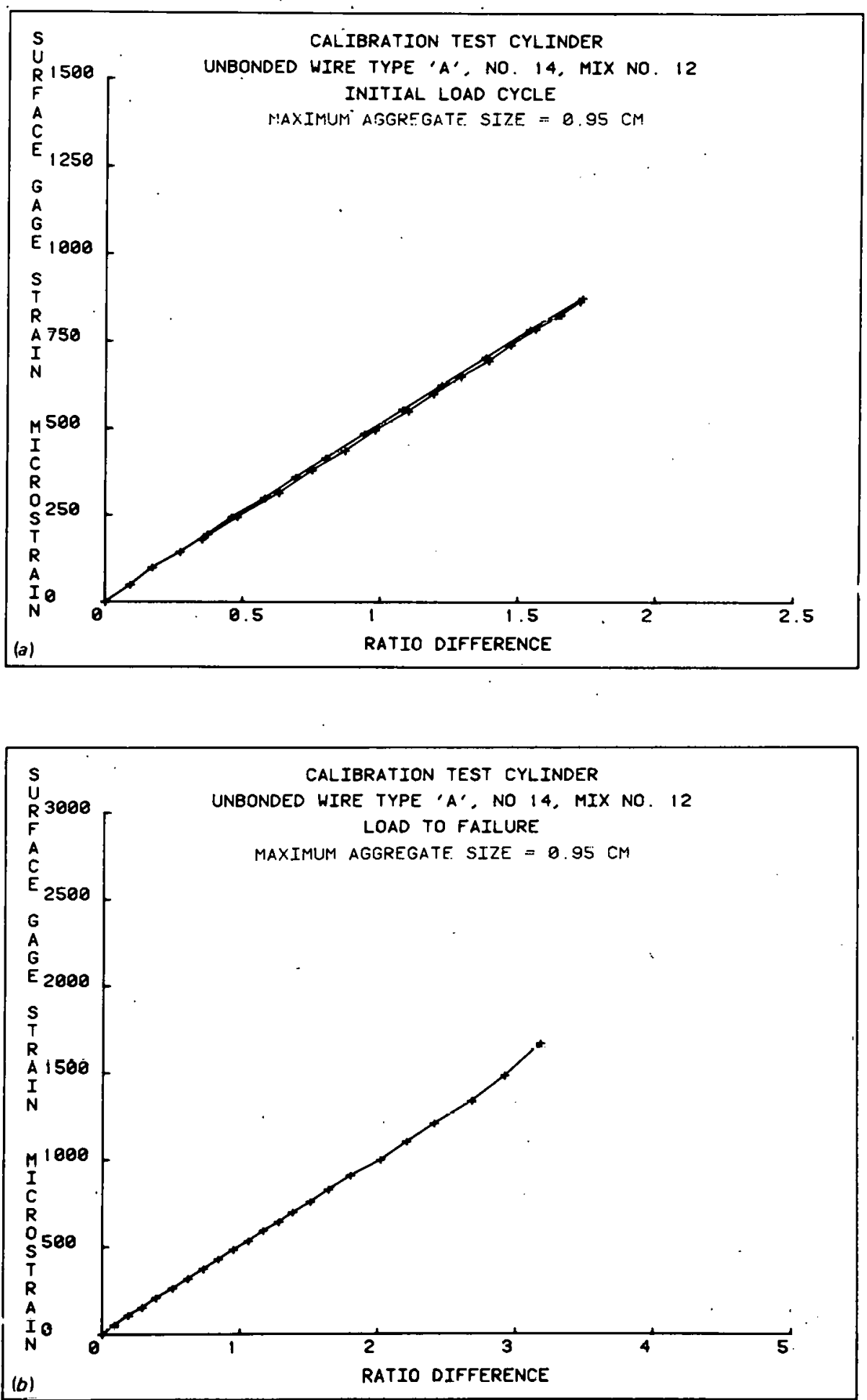

Fig. 41. Surface strain gage vs embedded gage output (unbonded wire gage, Type A, No. 14). 
ORNL-OWG 78-4484
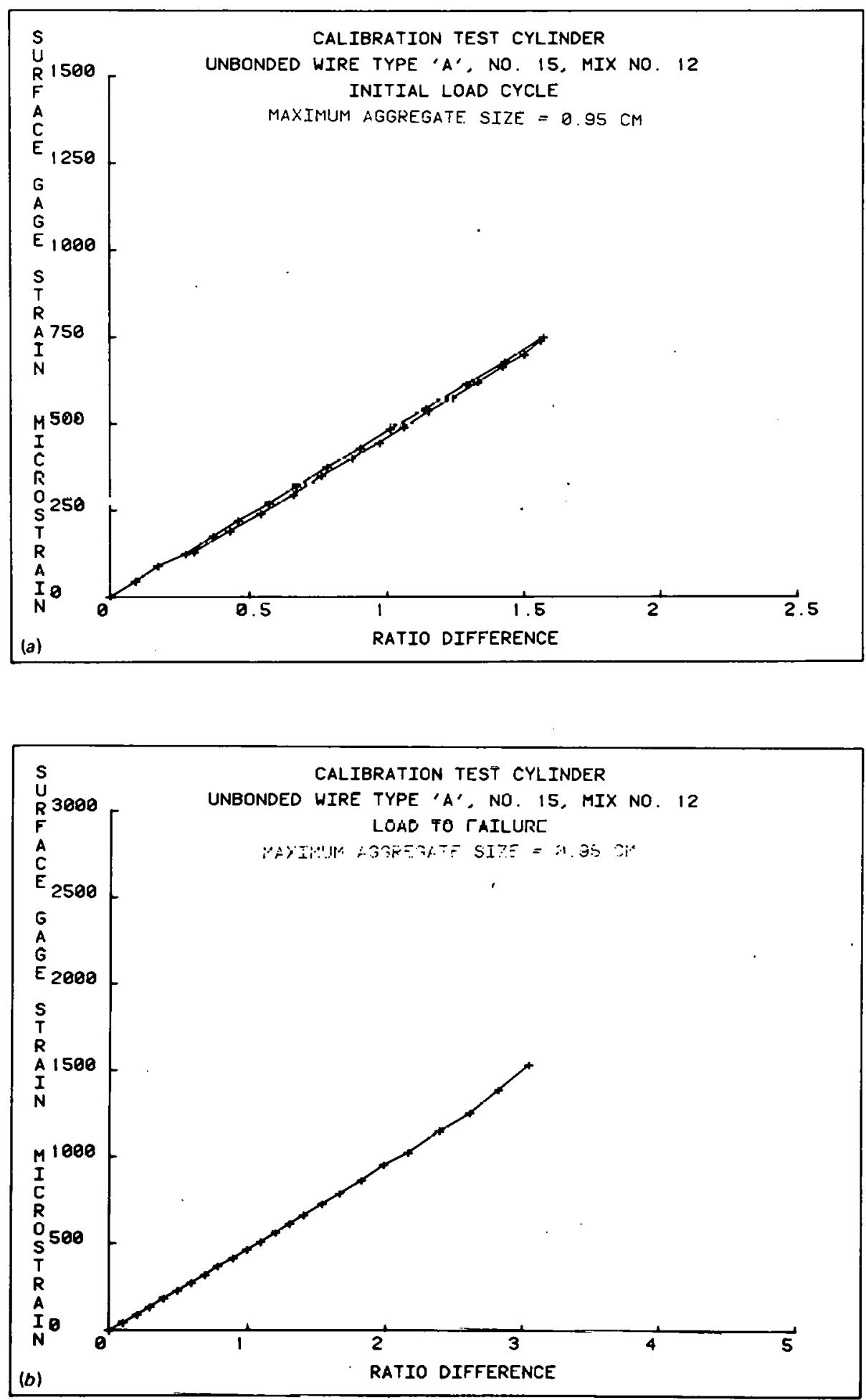

Fig. 42. Surface strain gage vs embedded gage output (unbonded wire gage, Type A, No. 15). 
ORNL-DWG 78-.4485
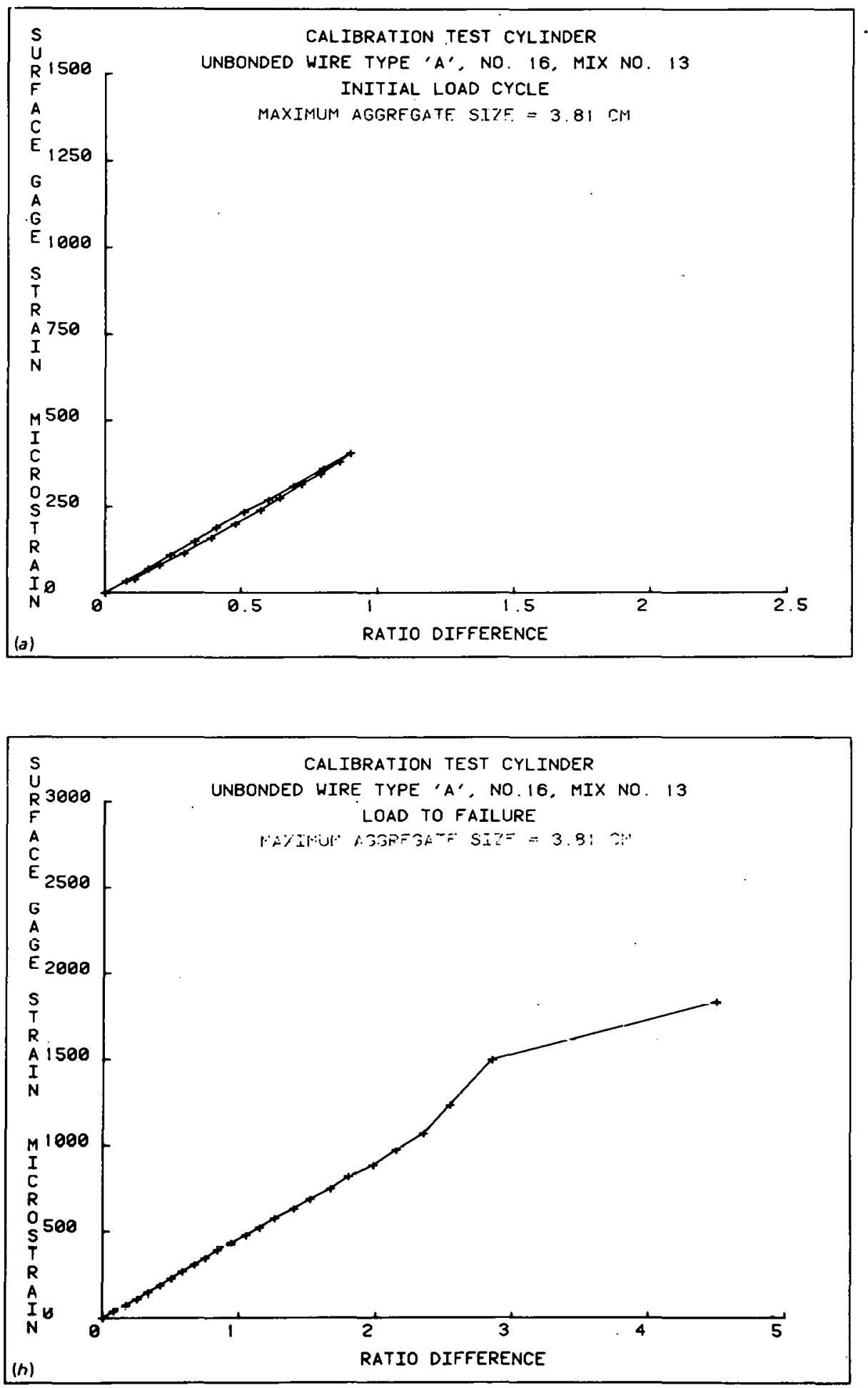

Fig. 43. Surface strain gage vs embedded gage output (unbonded wire gage, Type A, No. 16). 
ORNL-DWG 78-4486
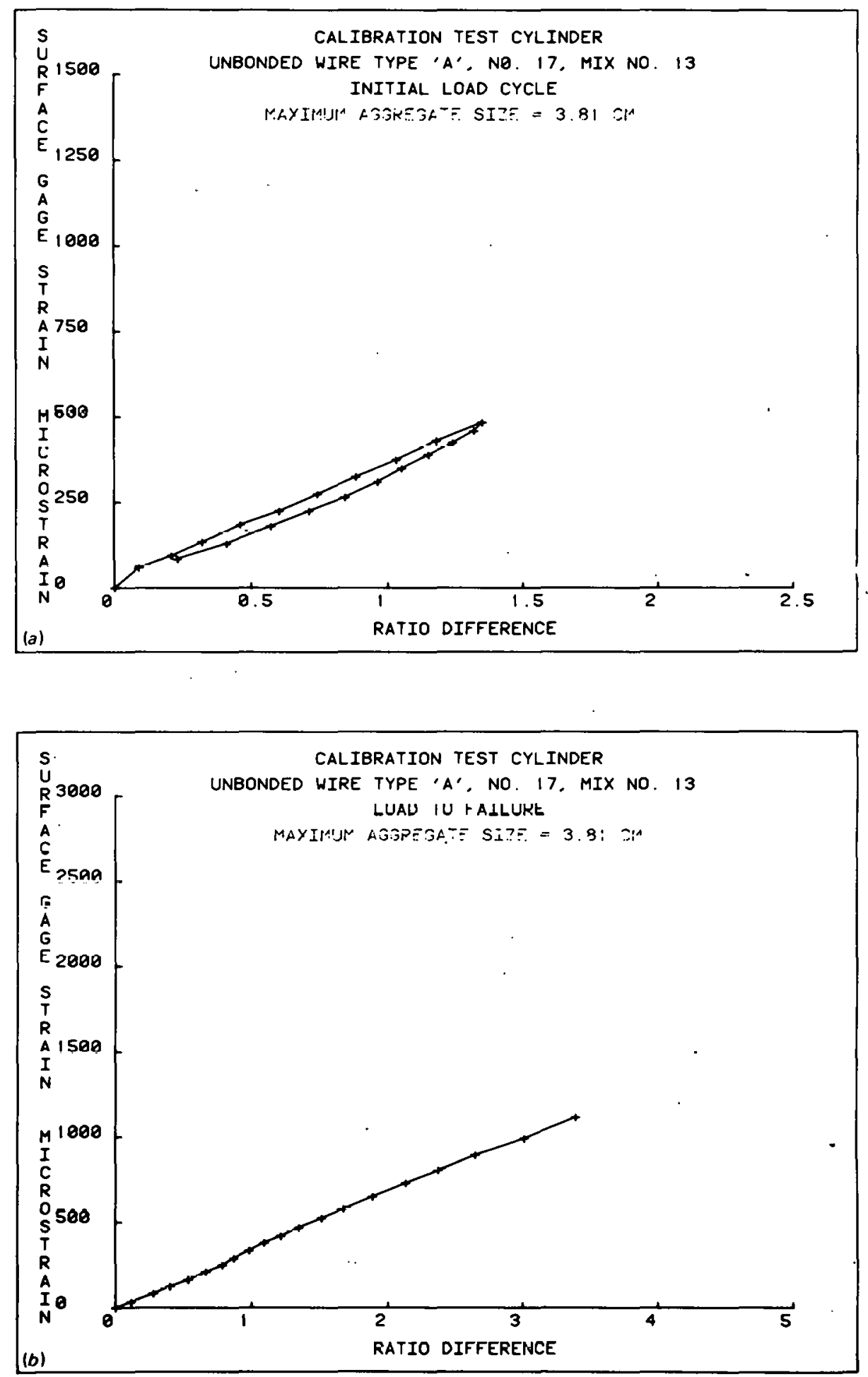

Fig. 44. Surface strain gage vs embedded gage output (unbonded wire gage, Type A, No. 17). 
ORNL-DWG 78-4487
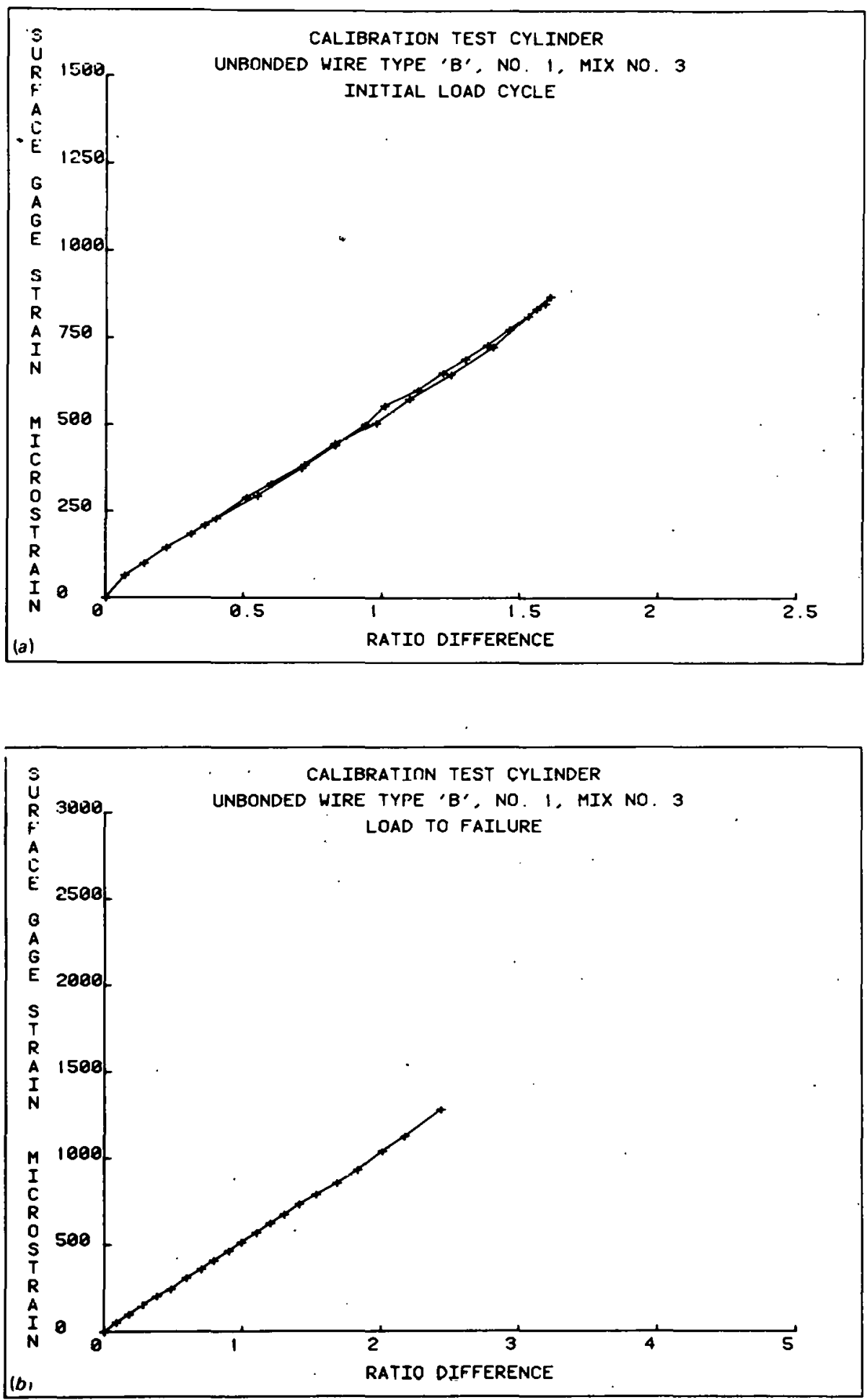

Fig. 45. Surface strain gage vs embedded gage output (unbonded wire . gage, Type $\mathrm{B}$, No, 1). 
OKNL-OWG 78-4488
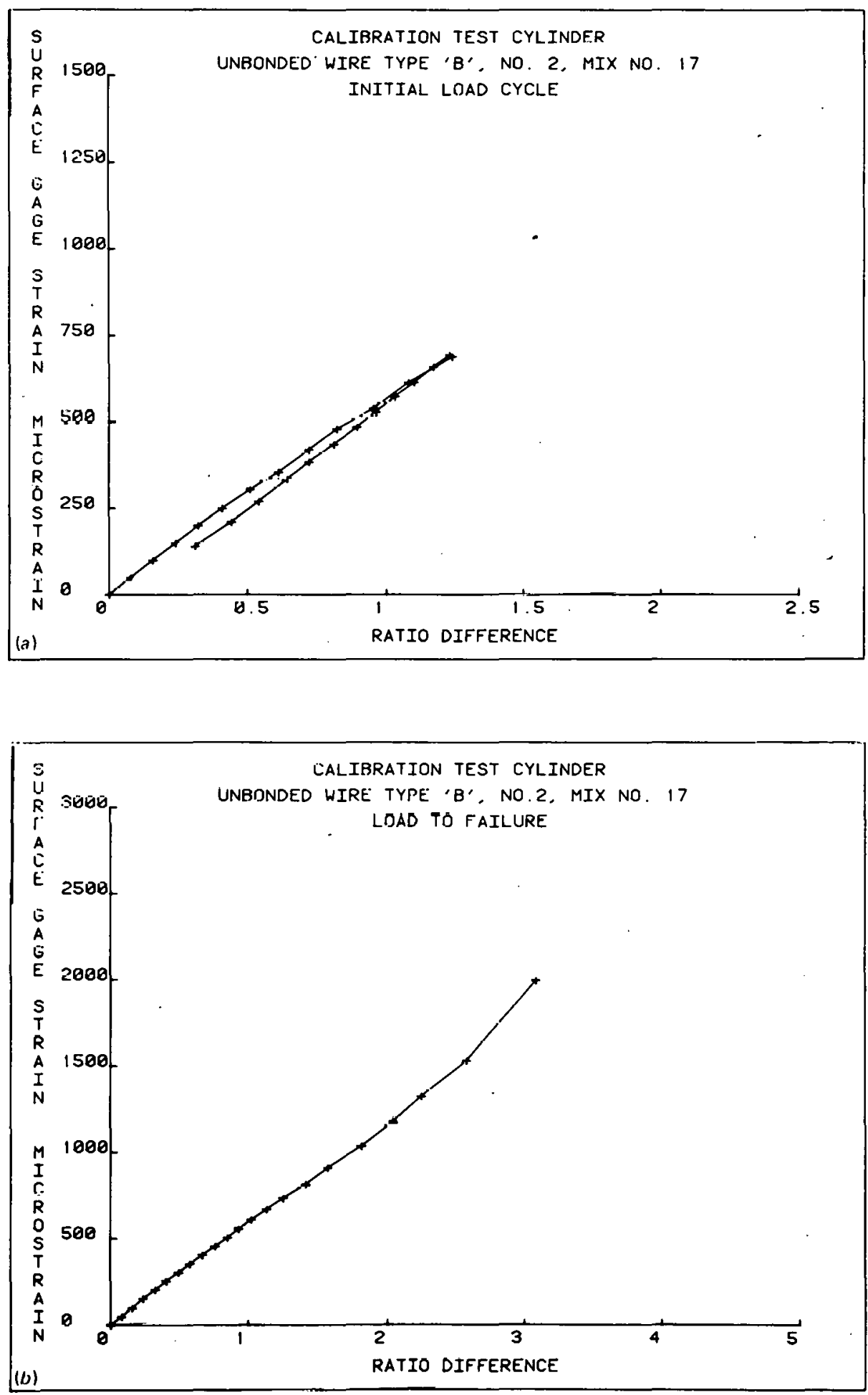

Fig. 46. Surface strain gage vs embedded gage output (unbonded wire gage, Type B, No. 2). 
ORNL-DWG 78-4489
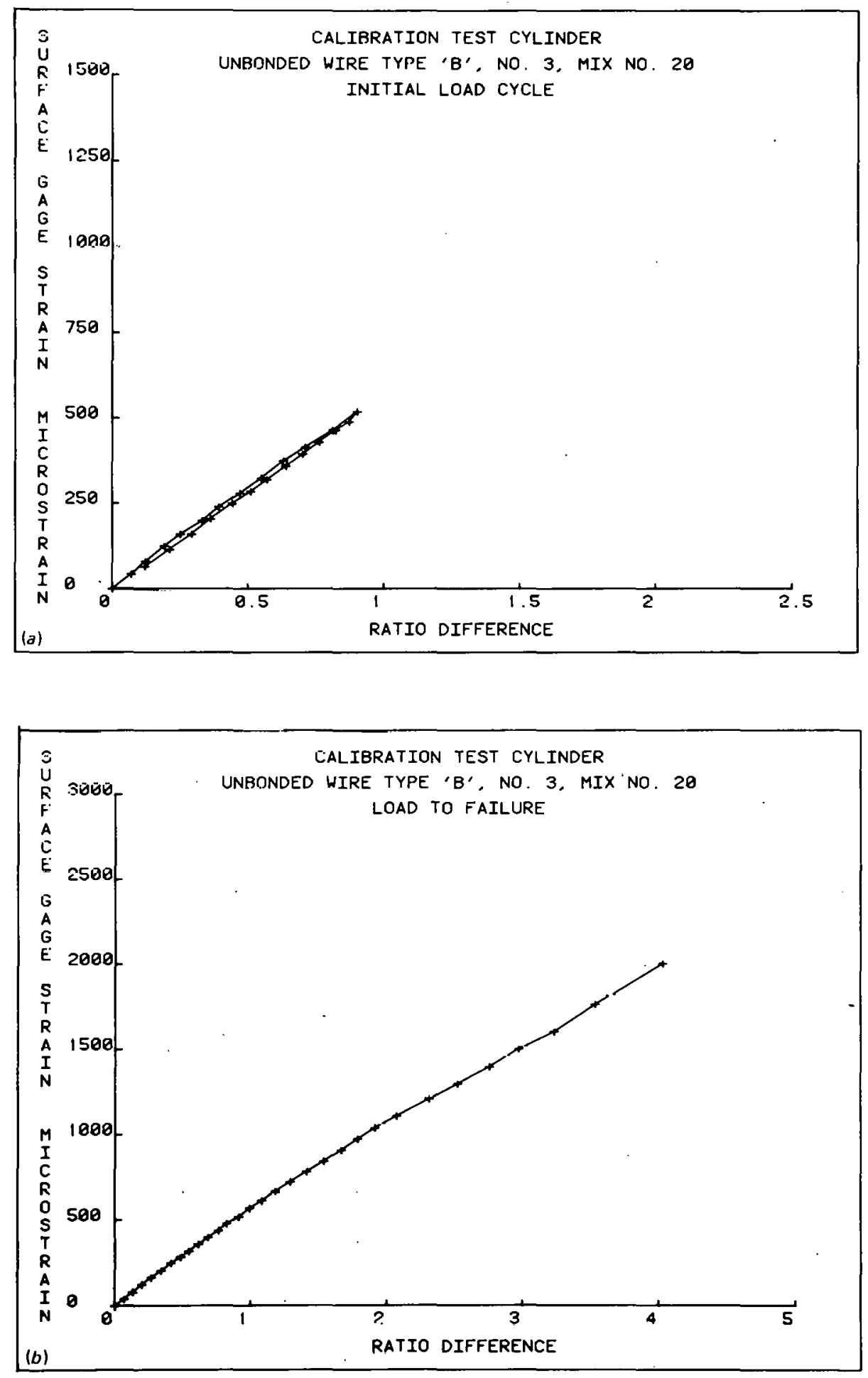

Fig. 17. Surfare strain gage vs embedded gage output (unbonded wire gage, Type B, No. 3). 
ORNL-DWG 78-4490
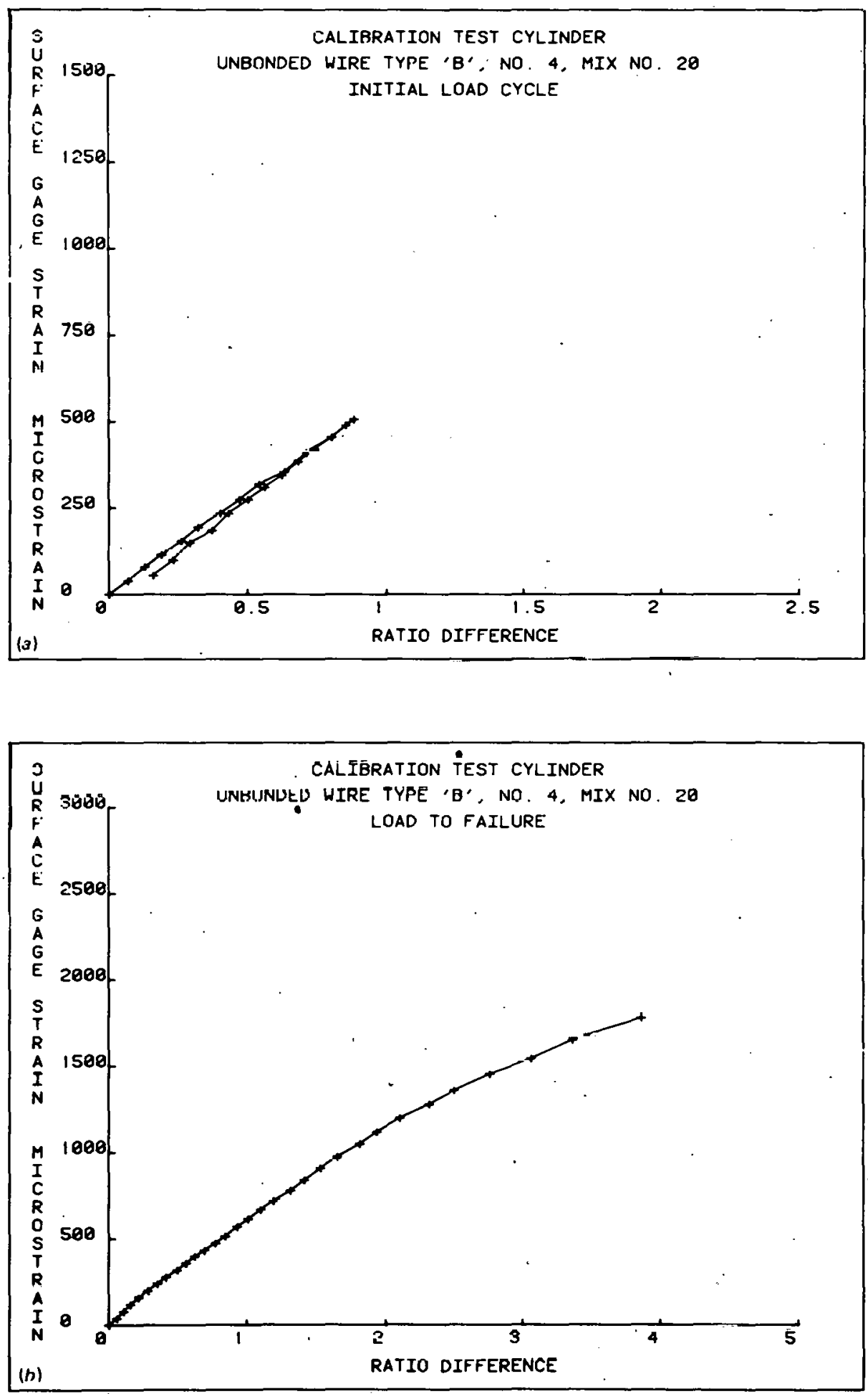

Fig. 48. Surface strain gage vs embedded gage output (unbonded wire gage, Type B, No. 4). 
ORNL-DWG 78-4491
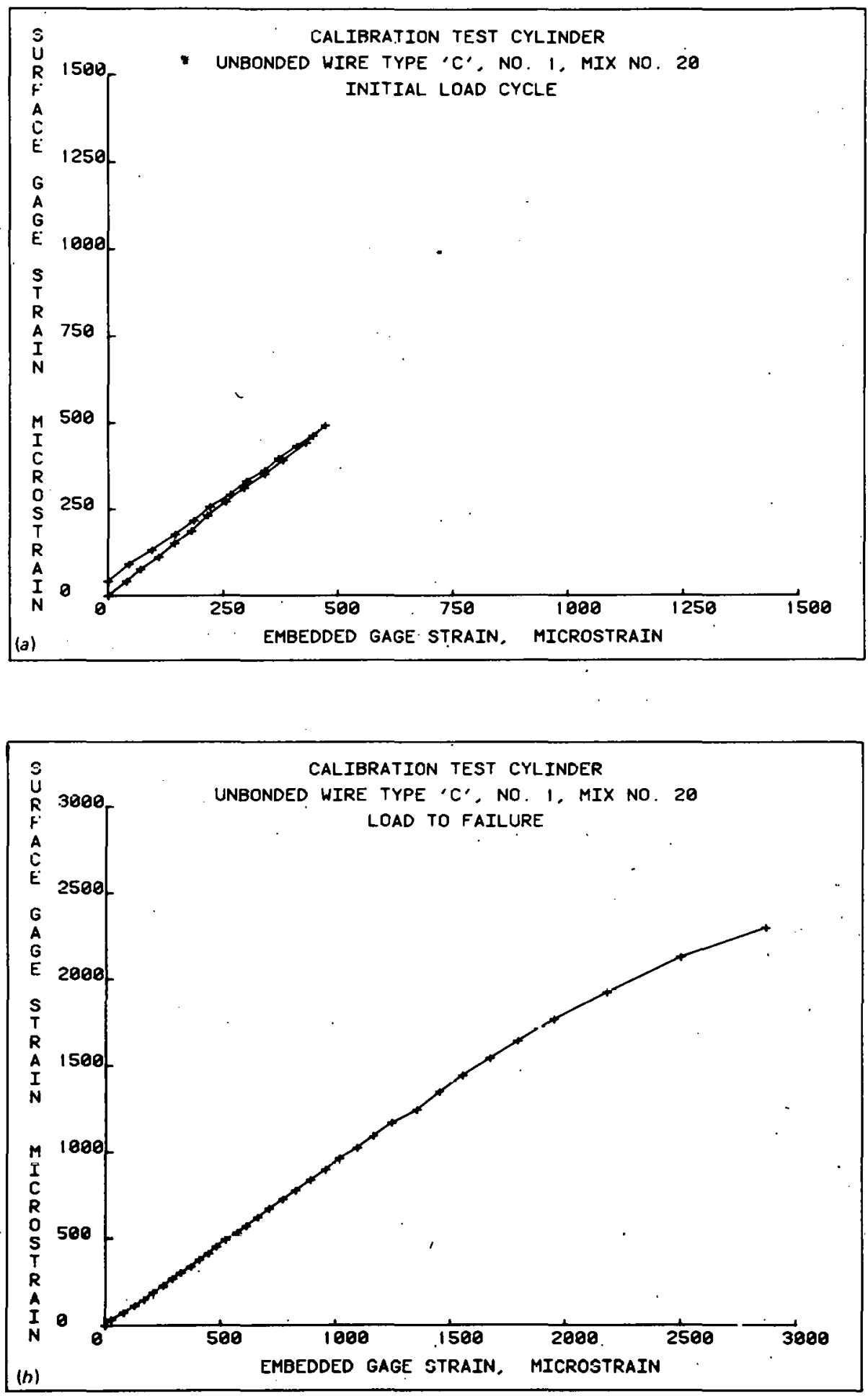

Fig. 49. Surface strain gage vs embedded gage output (unbonded wire gage, 'lype (., No. 1). 
ORNL-DWG 78-4492
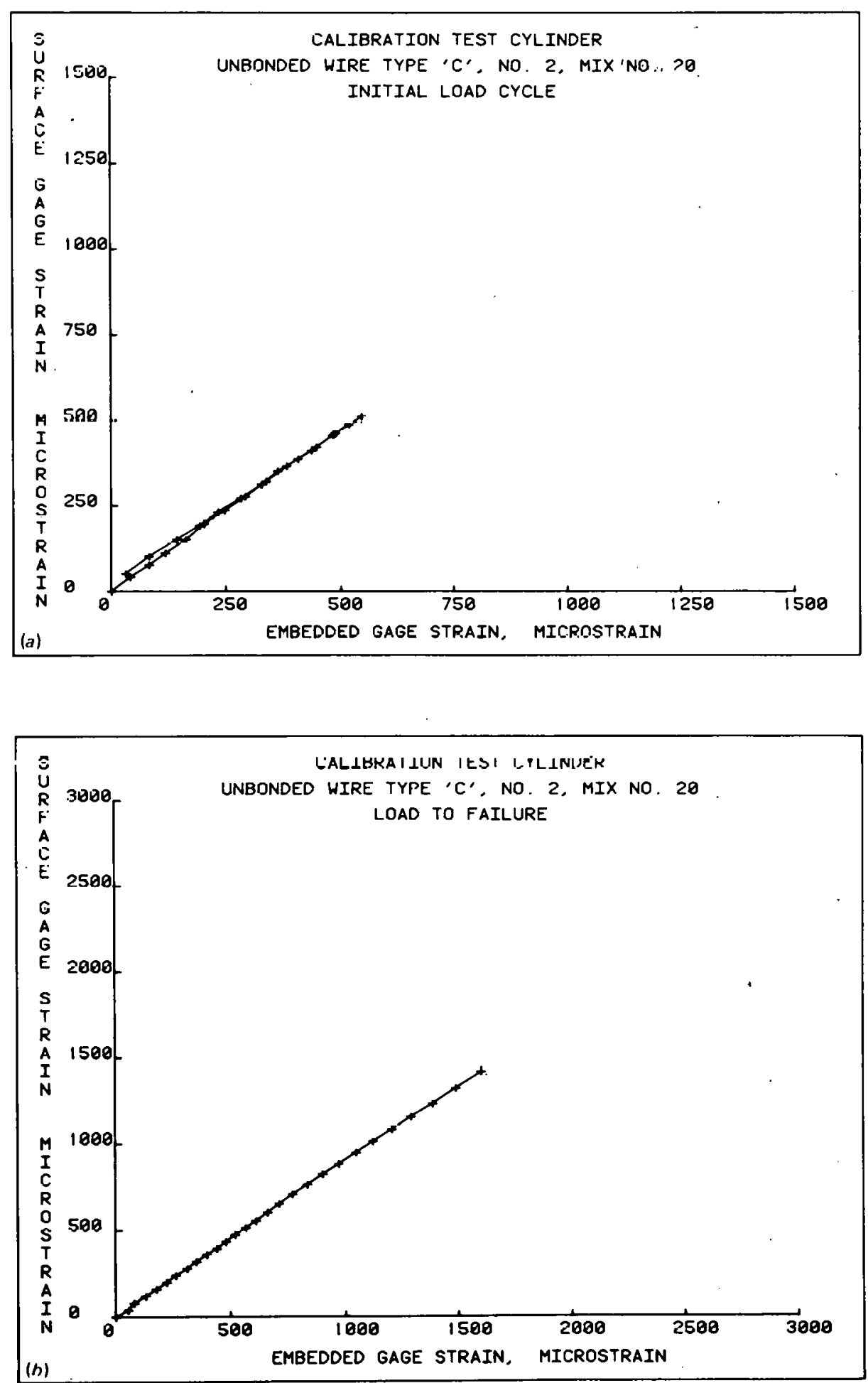

Fig. 50. Surface strain gage vs embedded gage output (unbonded wire gage, Type C, No. 2). 
ORNL-DWG 78-4493
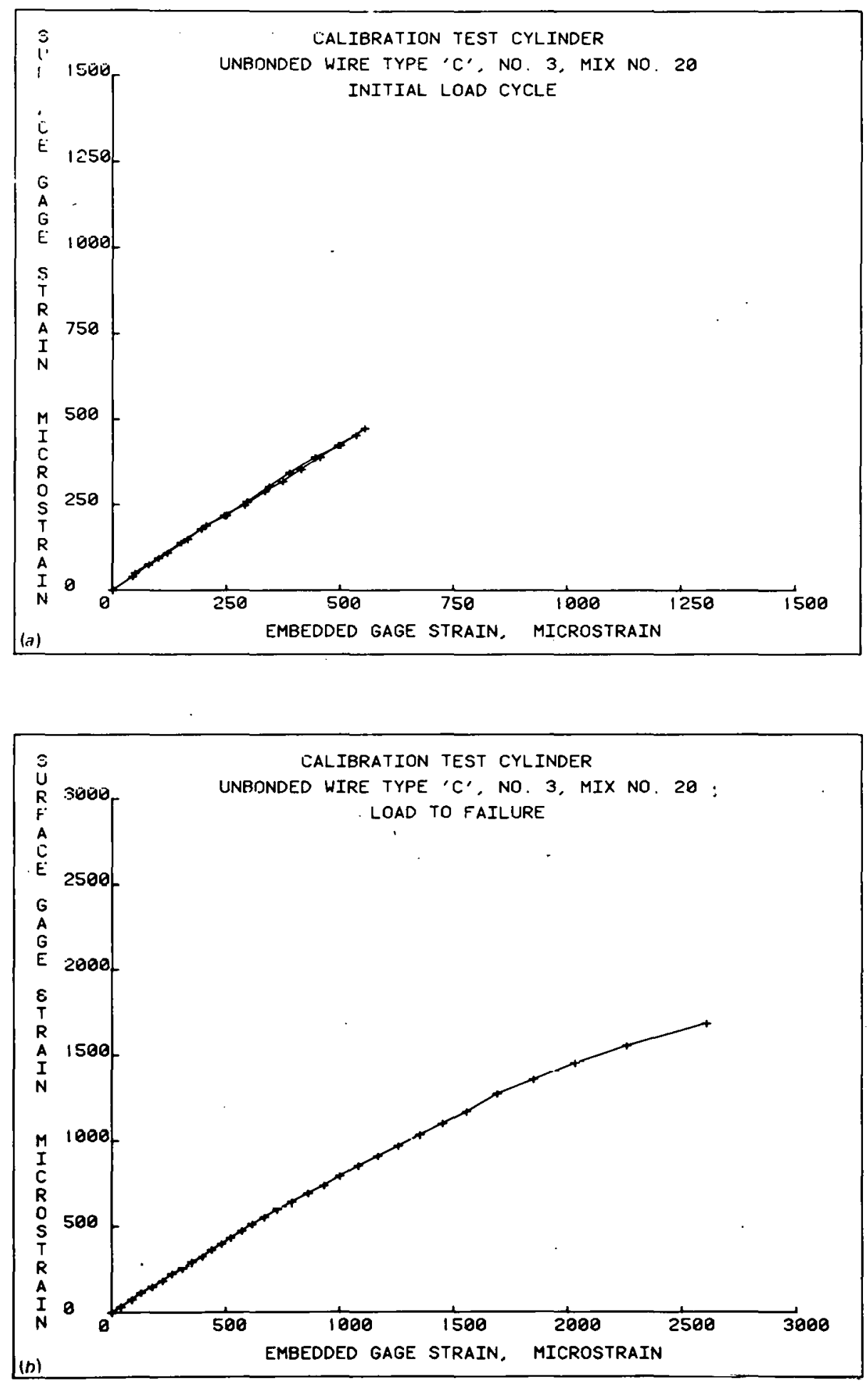

Fig. 51. Surfare strain gage vs embedded gage output (unbonded wire gage, Type C, No. 3). 
ORNL-DWG 78-4494
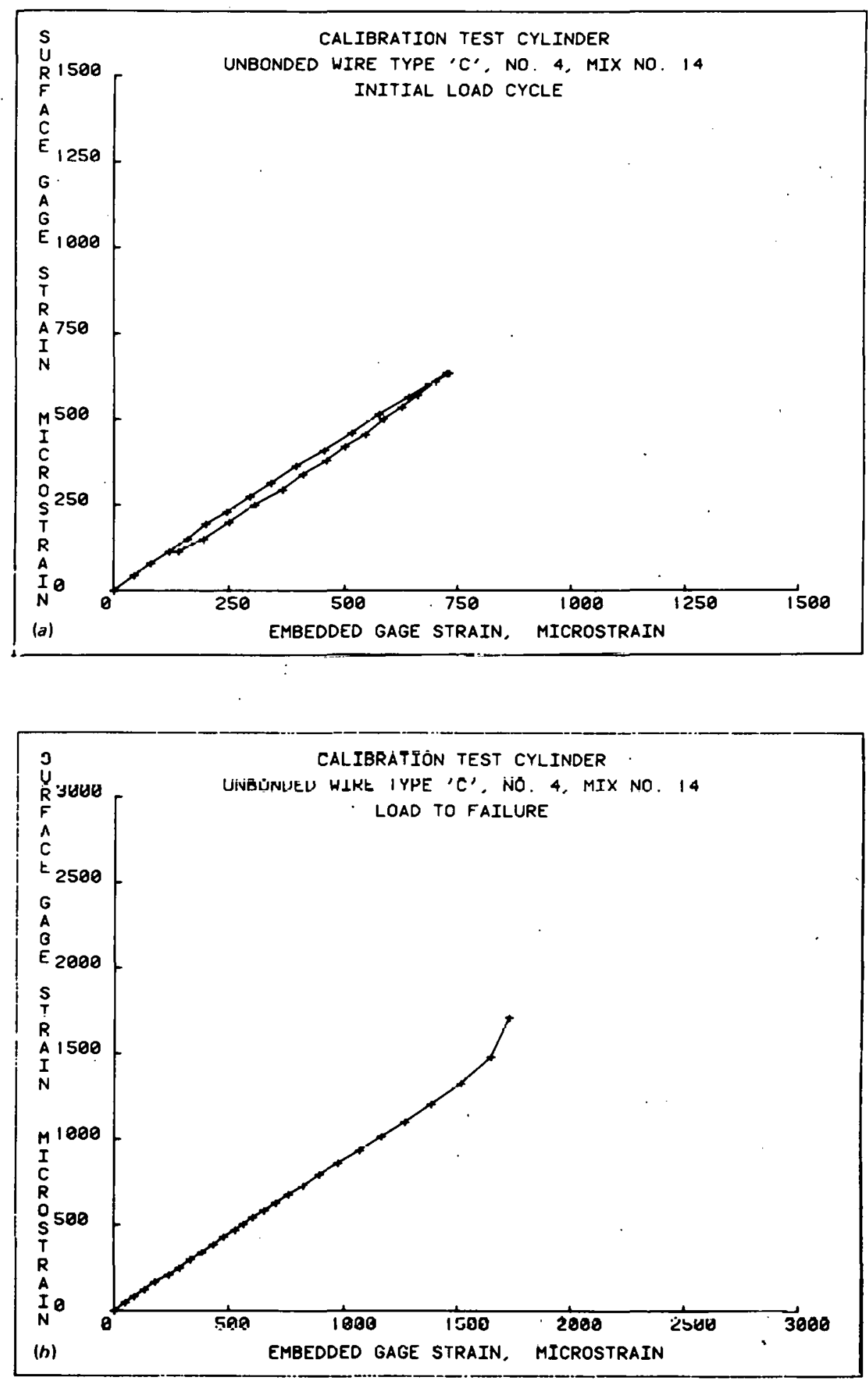

Fig. 52. Surface strain gage vs embedded gage output (unbonded gage, Type C, No. 4). 

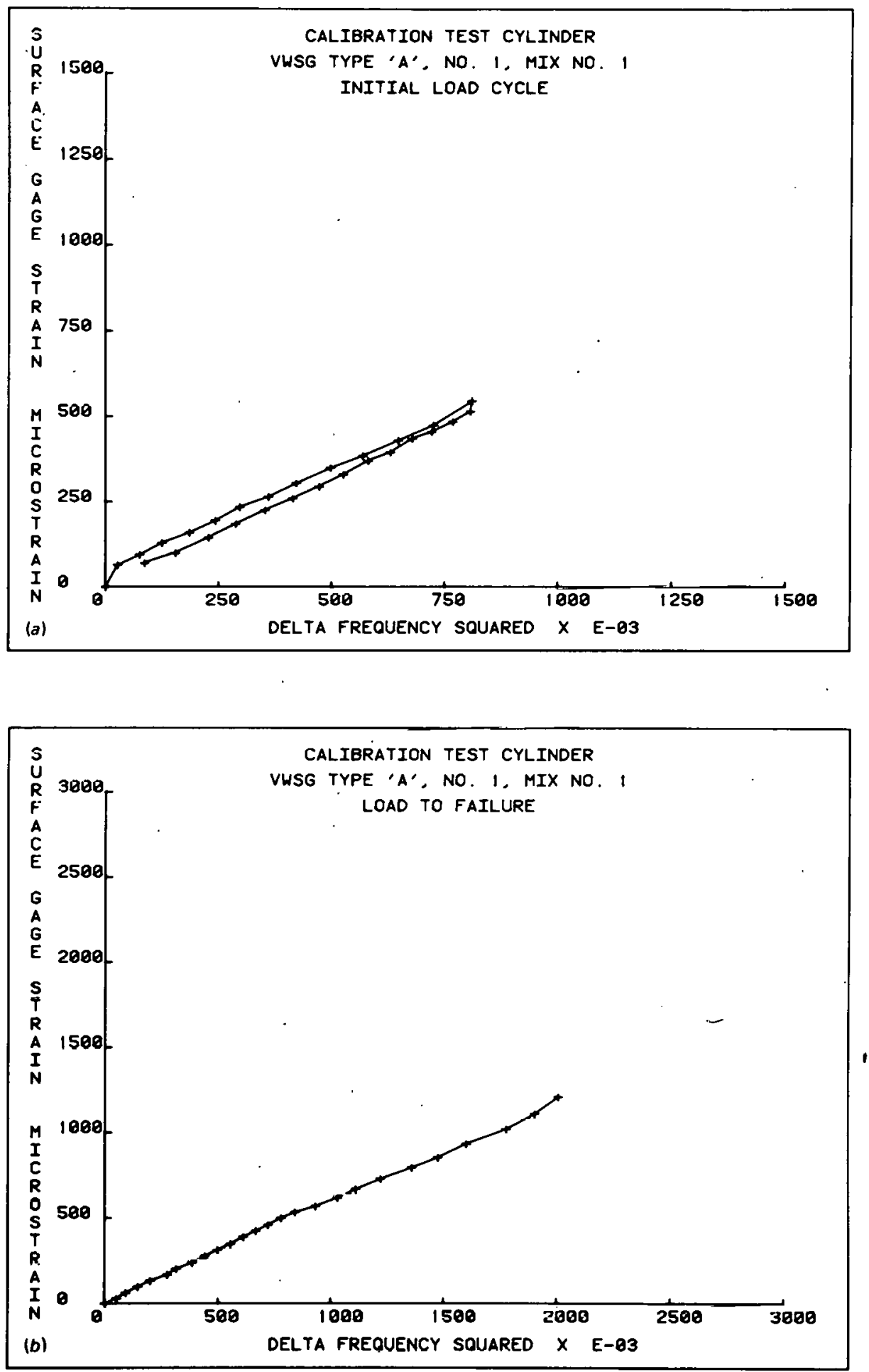

Fig. 53. Surface strain gage vs embedded gage output (VWSG, Type A, No. 1). 
ORNL-DWG 78-4496
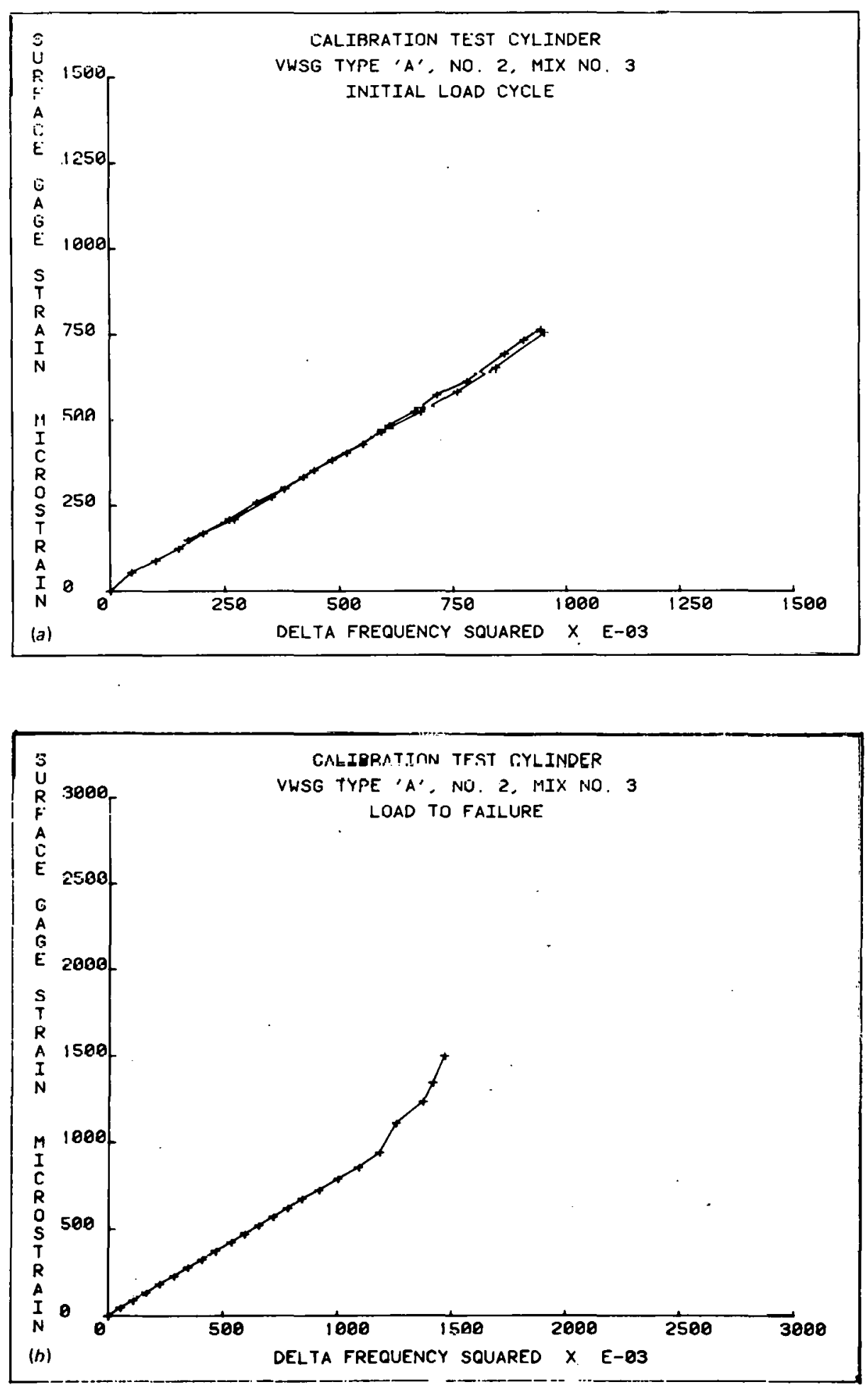

Fig. 54. Surface strain gage vs embedded gage output (VWSG, Type A, No. 2). 
ORNL-DWG 78-4497
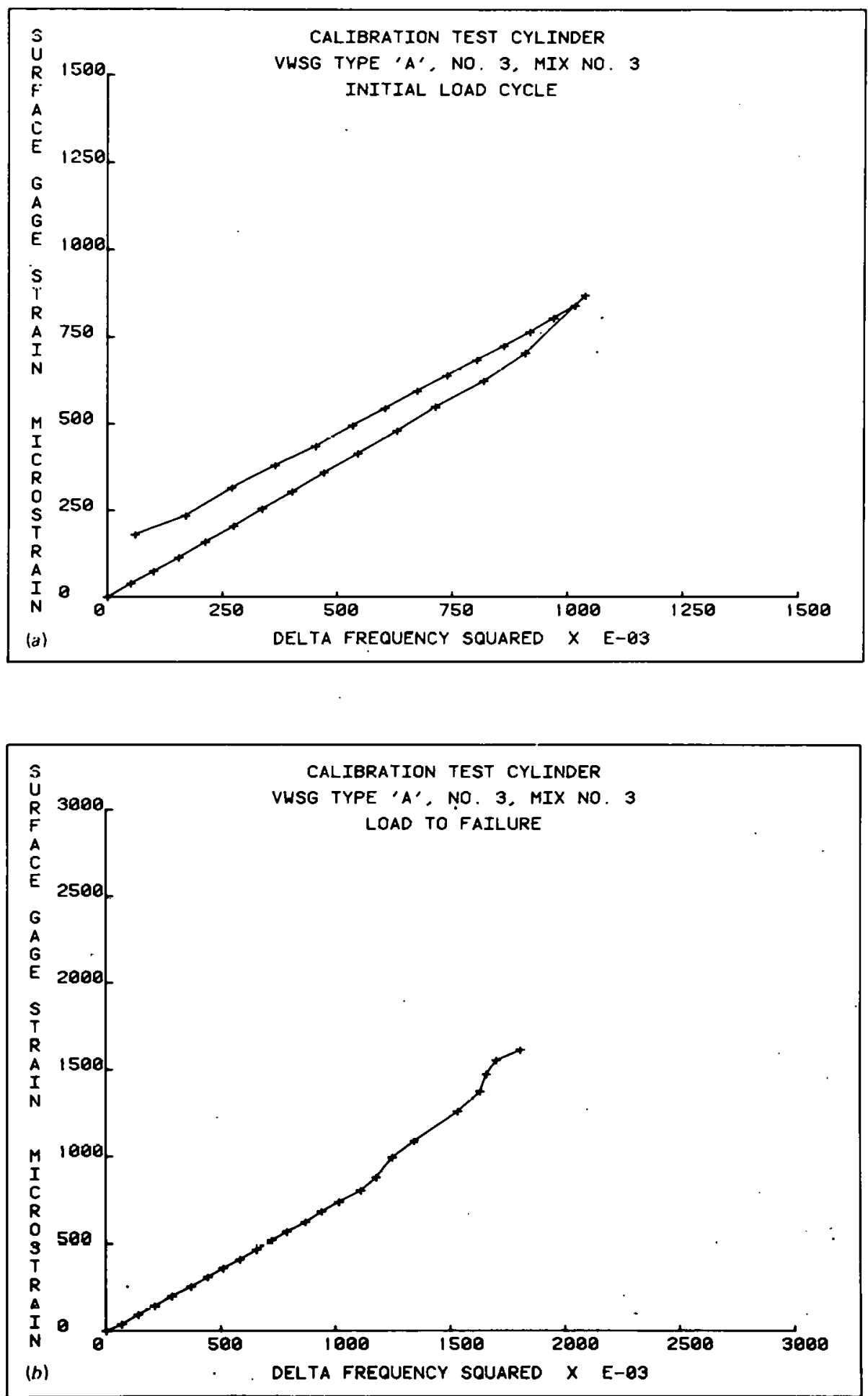
No, 3) .

Fig. 55. Surface strain gage vs embedded gage output (VWSG, Type A, 
ORNL-DWG 78-4498
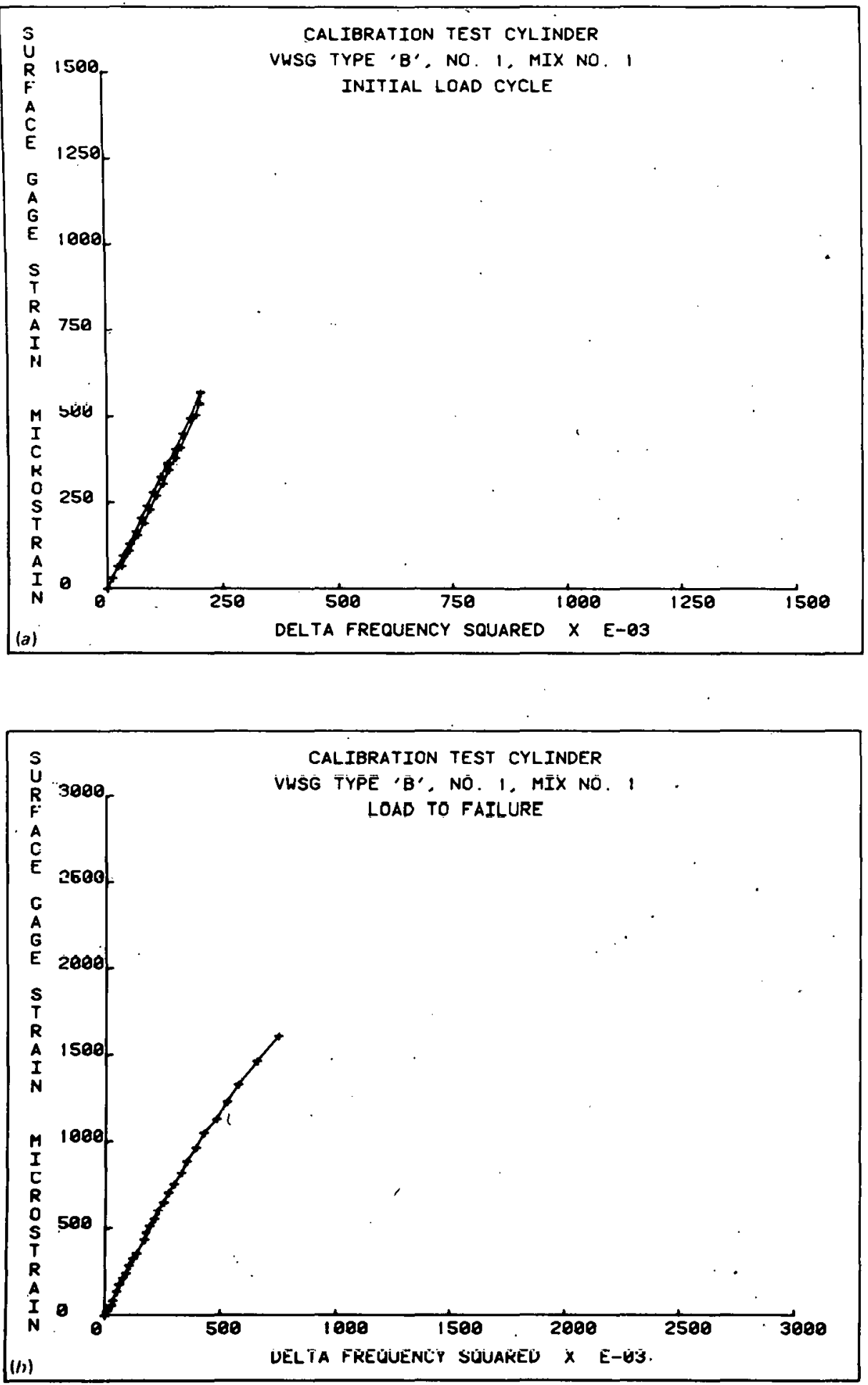

Fig. 56. Surface strain gage vs embedded gage output (VWSG, Type B, No. 1). 
.

ORNL-DWG 78-4499
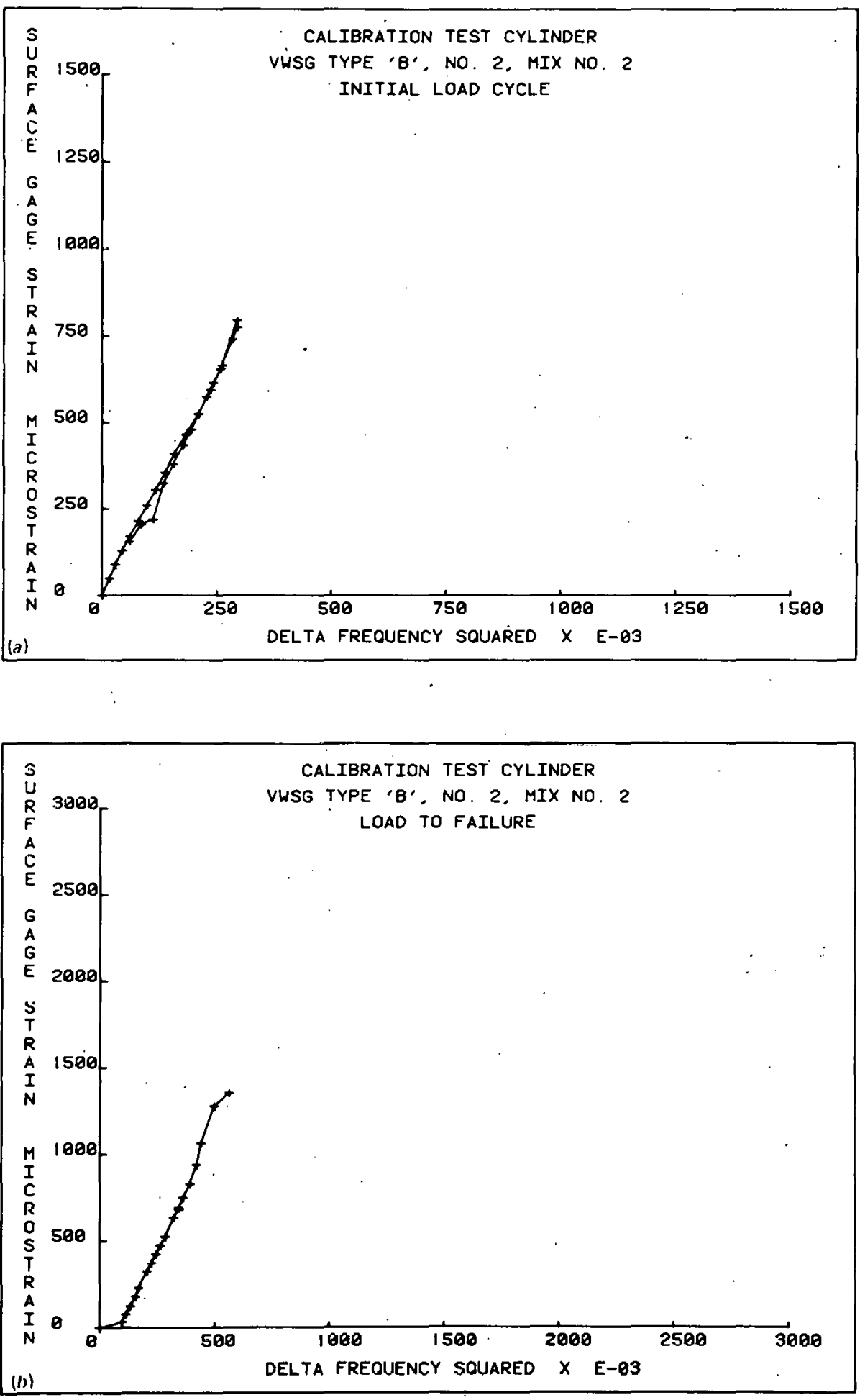

Fig. 57. Surface strain gage vs embedded gage output (VWSG, Type B, No. 2). 
ORNL-DWG 78-4500
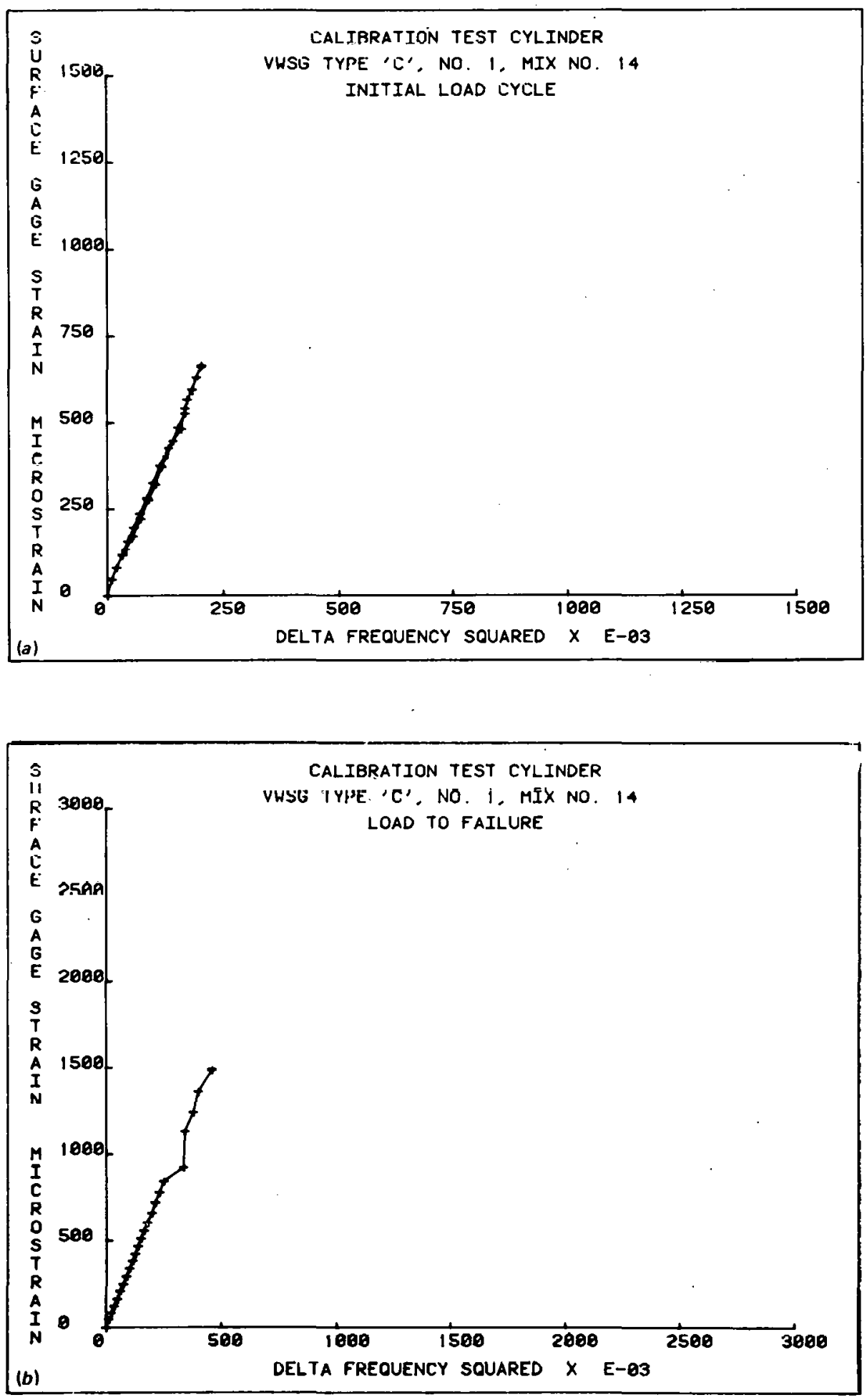

Fig. 58. Surface strain gage vs embedded gage output (VWSG, Typc C, No. 1). 
ORNL-DWG 78-4501
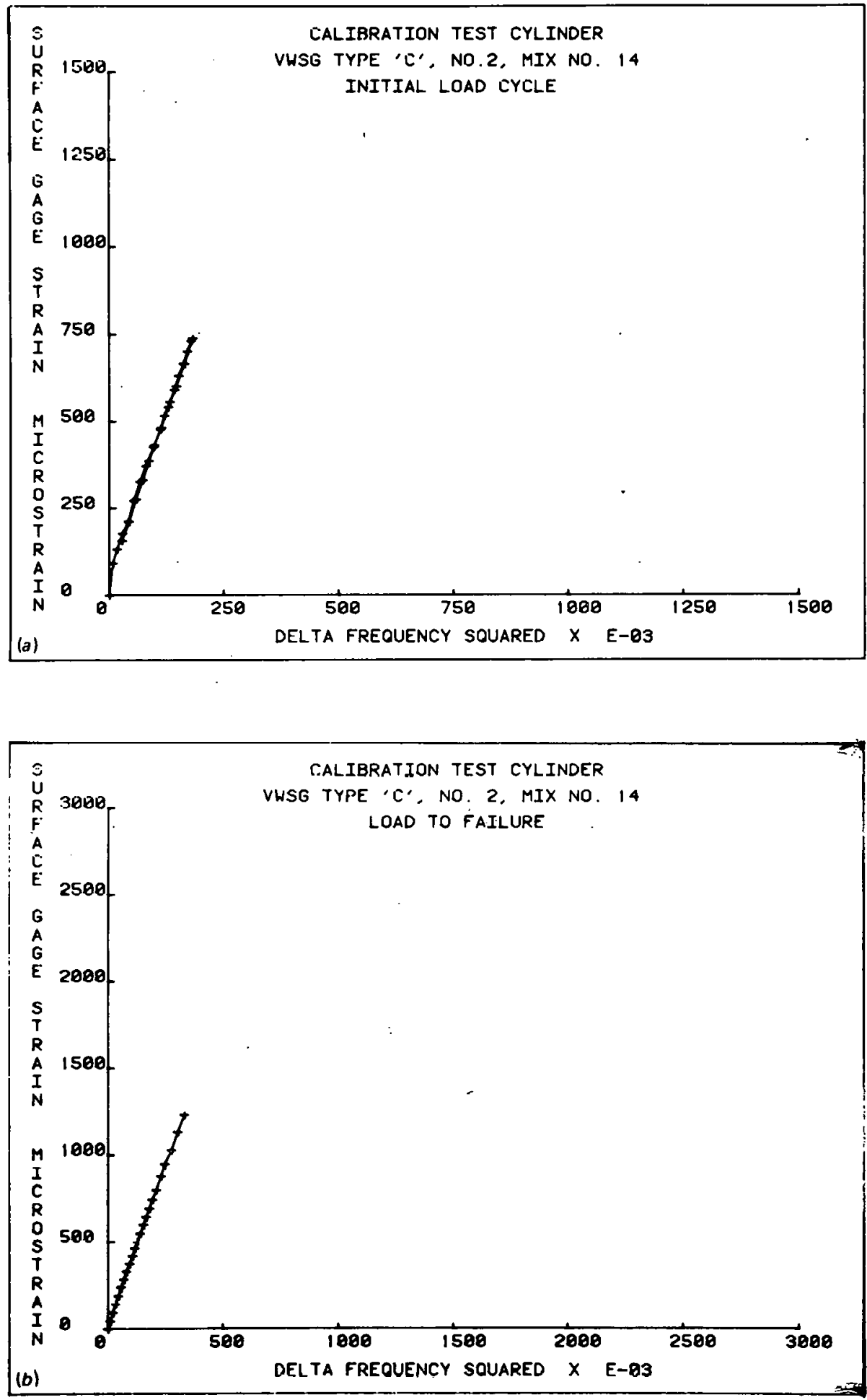

Fig. 59. Surface strain gage vs embedded gage output (VWSG, Type C, No. 2). 
ORNL-DWG 78-4502
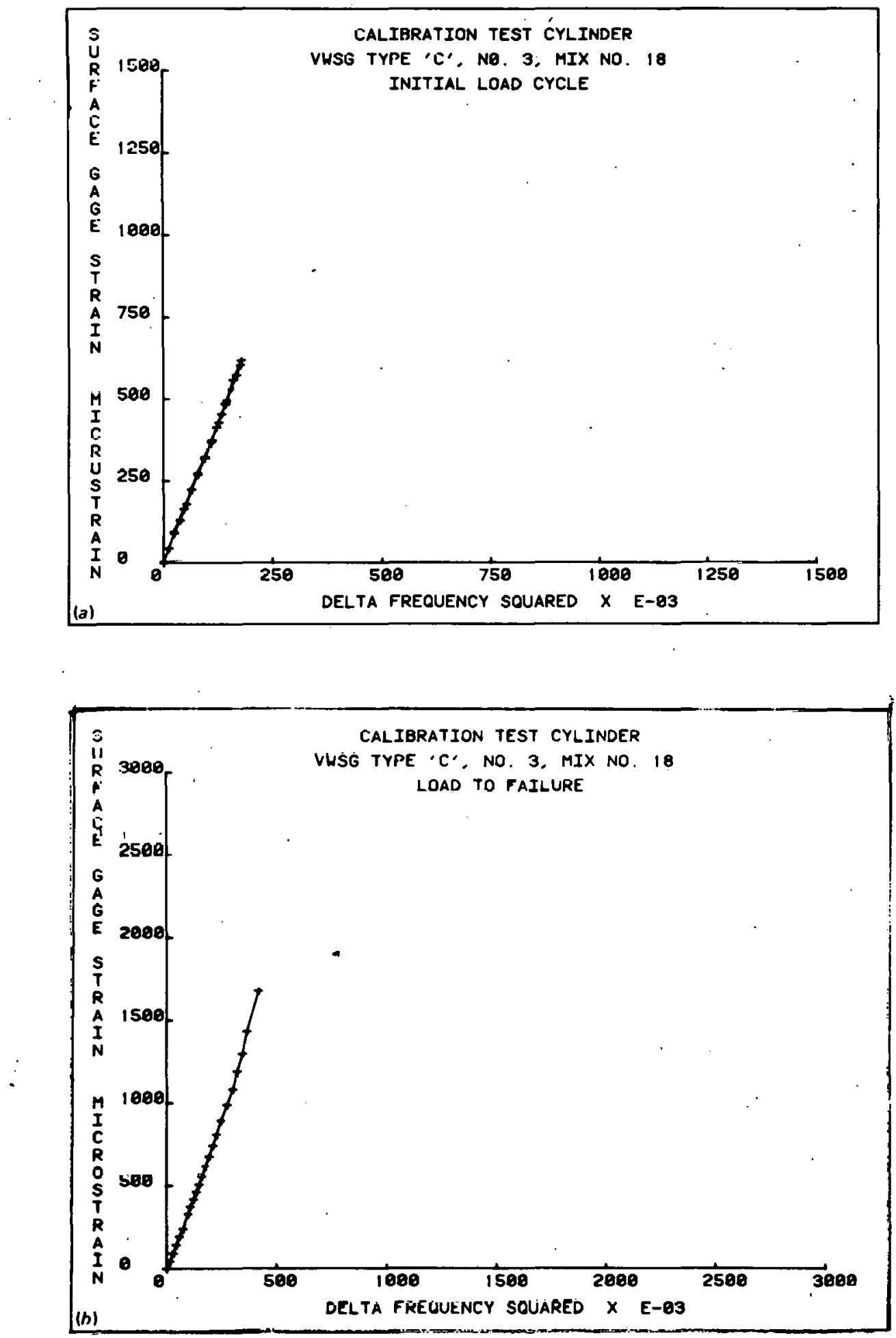

1

Fig. 60. Surface strain gage vs embedded gage output (VWSG, Type C, No. 3). 
ORNL-DWG 78-4503
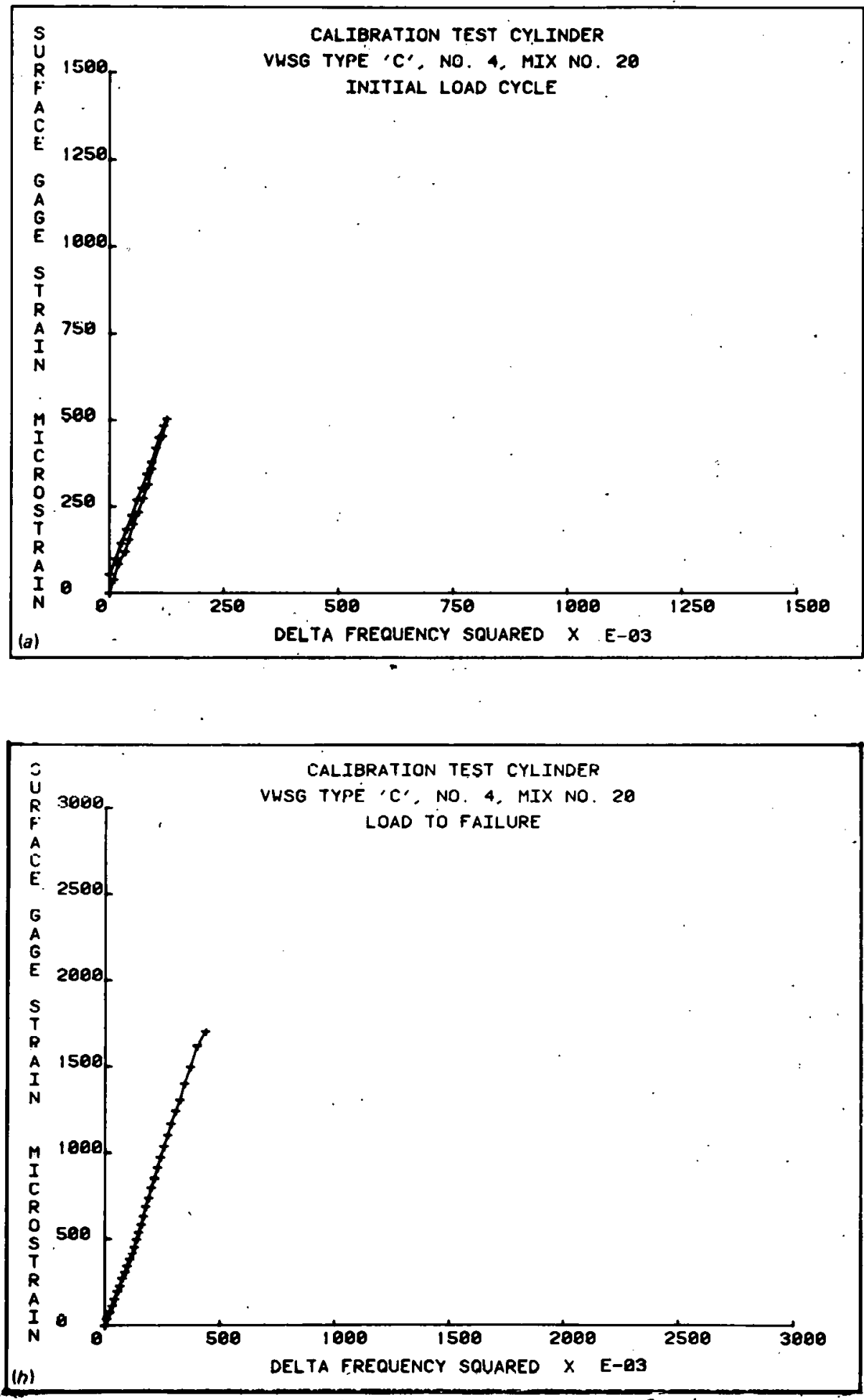

Fig. 61. Surface strain gage vs embedded gage output (VWSG, Type C, No. 4). 
ORNL-DWG 78-4504
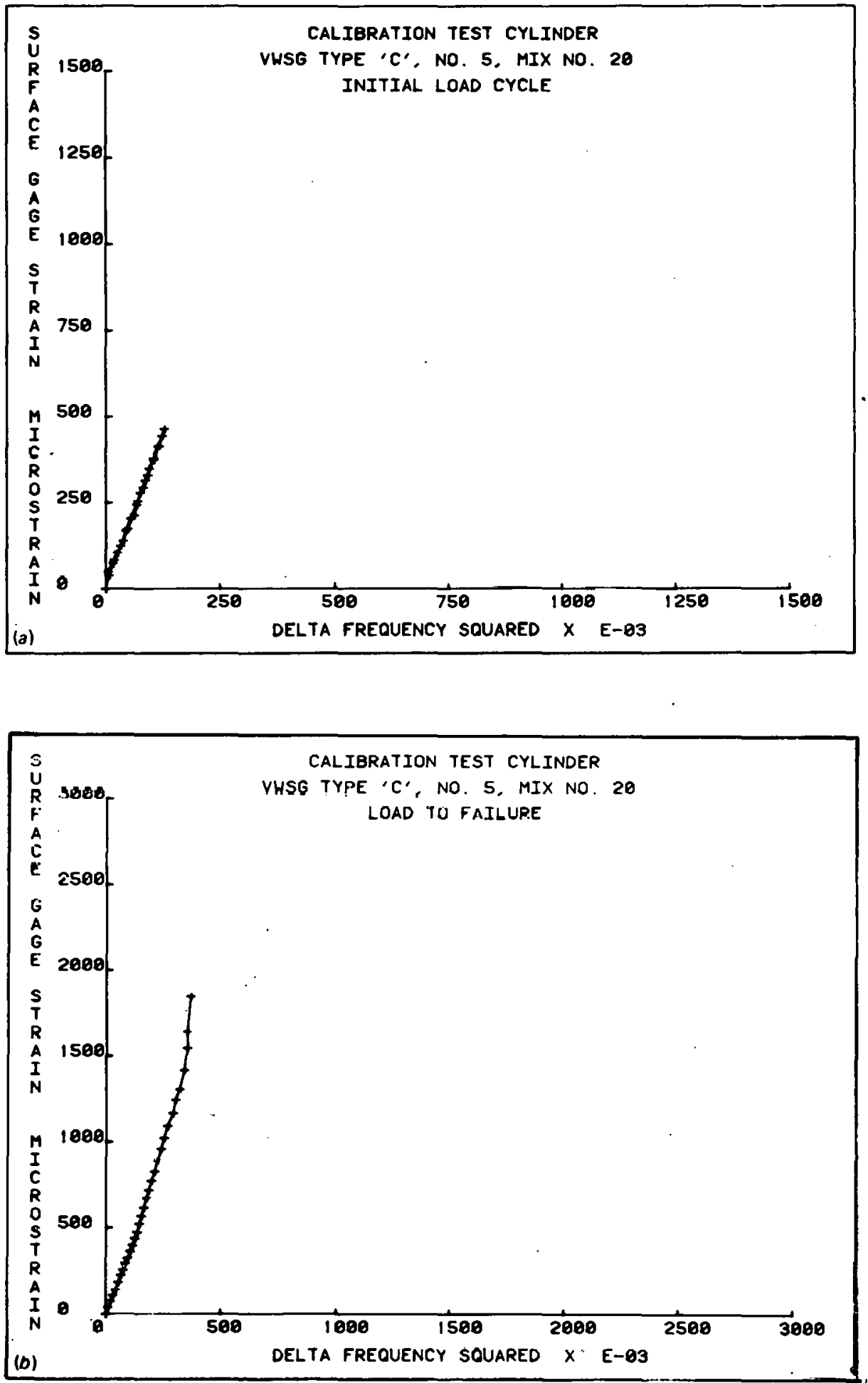

Fig. 62. Surface strain gage vs embedded gage output (VWSG, Type C, No. 5). 
ORNL-DWG 78-4505
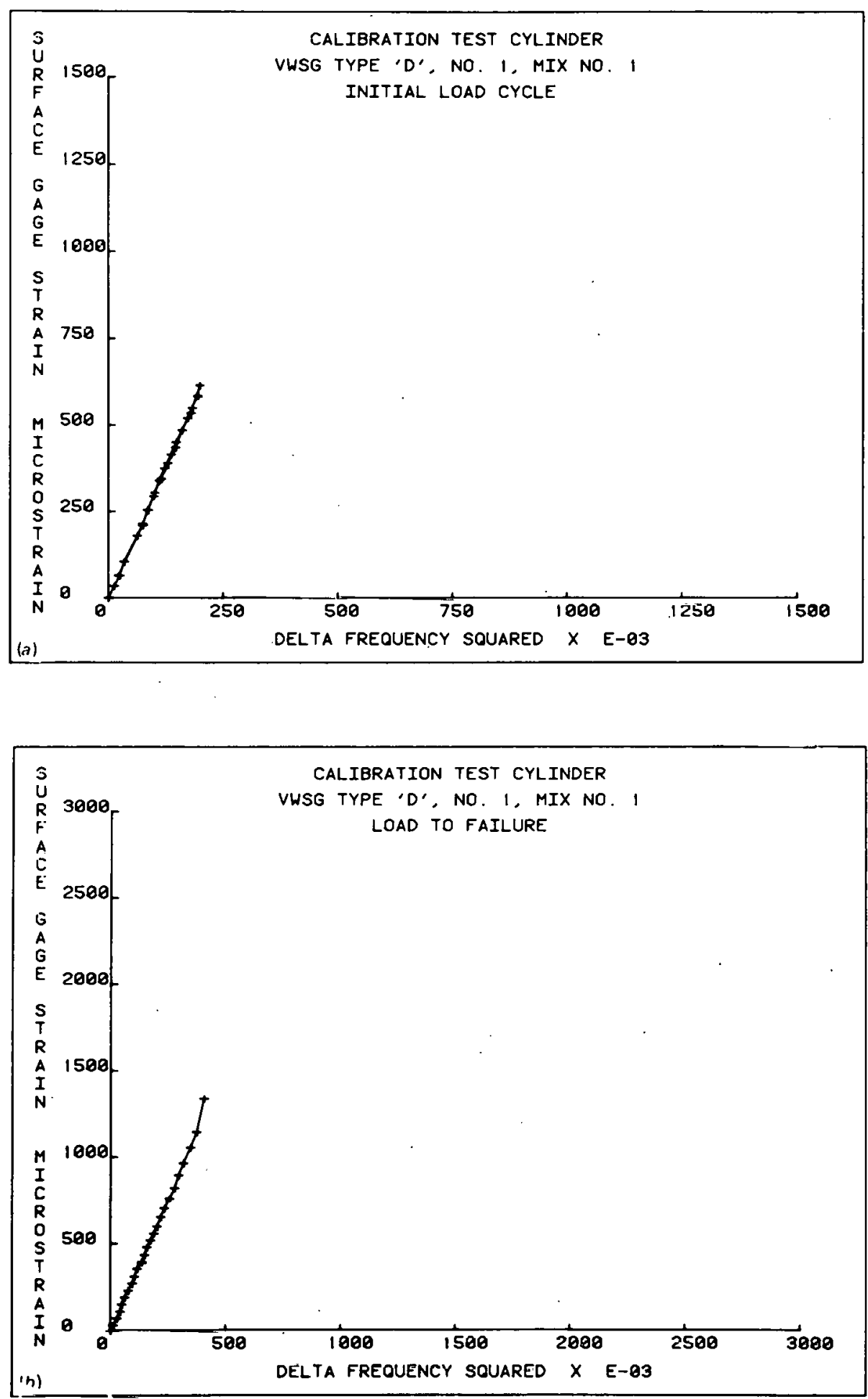

Fig. 63. Surface strain gage vs embedded gage output (VWSG, Type D, №. 1). 
ORNL-DWG 78-4506
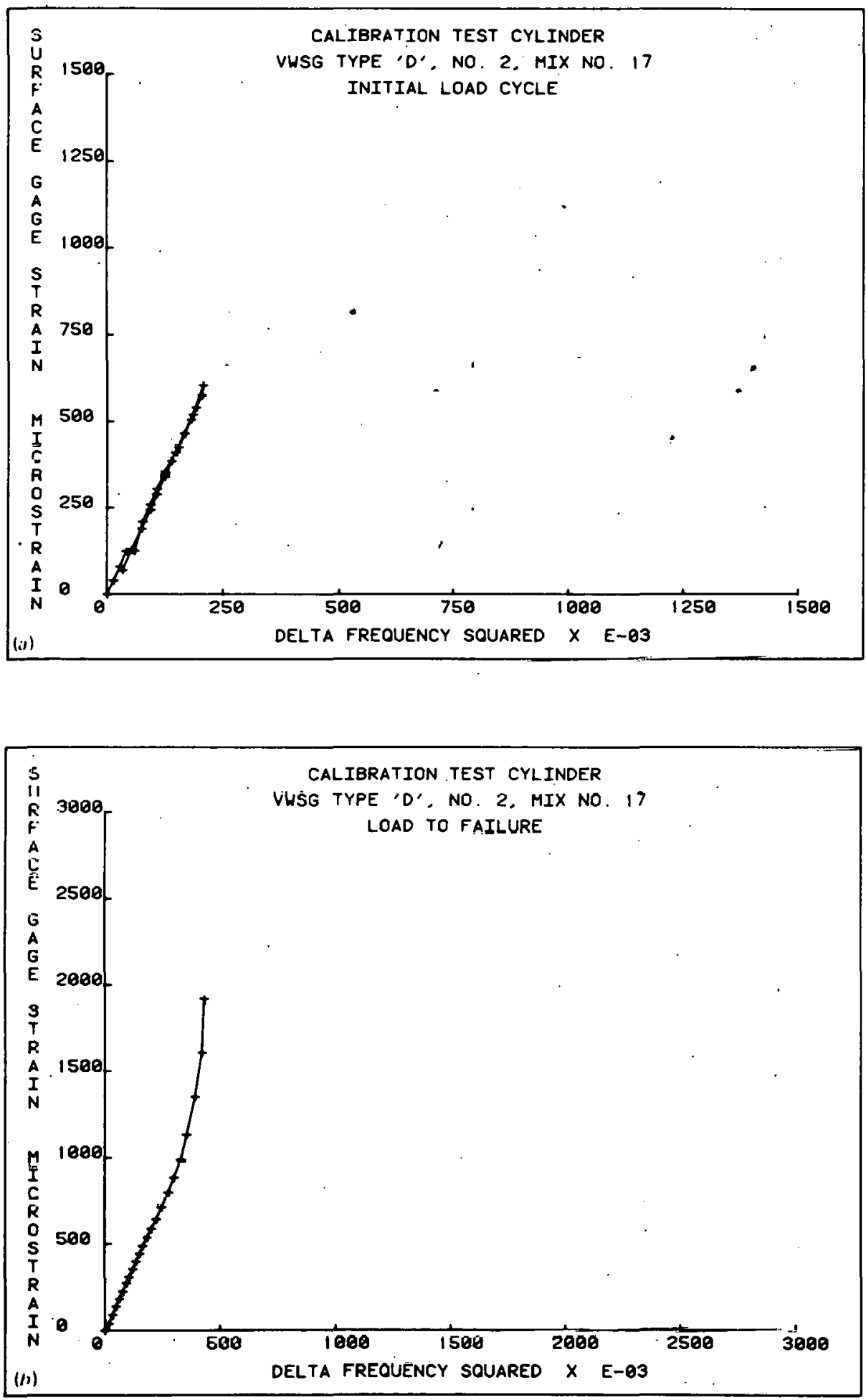

Fig. 64. Surface strain gage vs embedded gage output (VWSG, Type D, No. 2). 
ORNL-DWG 78-4507
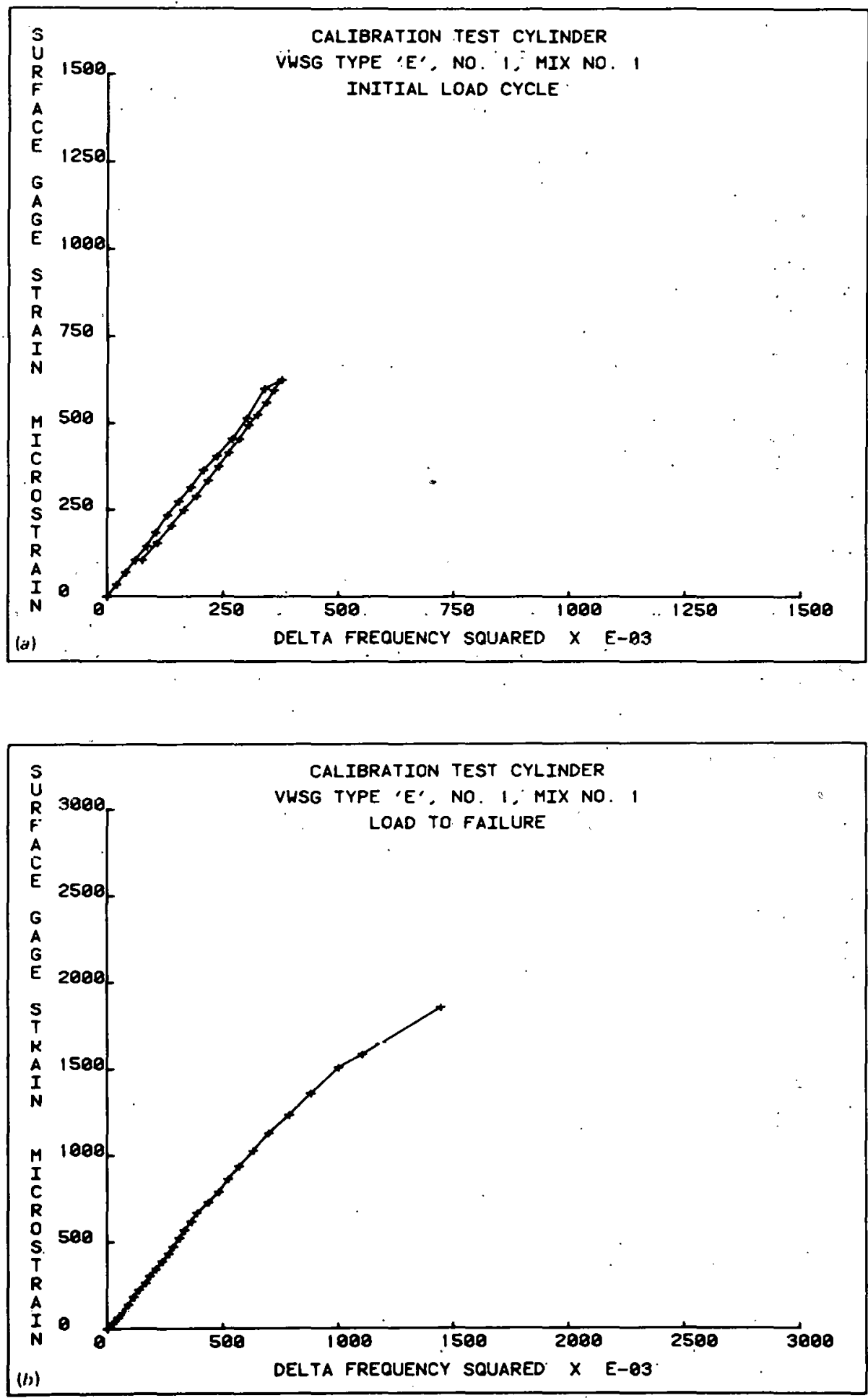

No. 1).

Fig. 65. Surface strain gage vs embedded gage output (VWSG, Type E, 
ORNL-OWG 78-4508
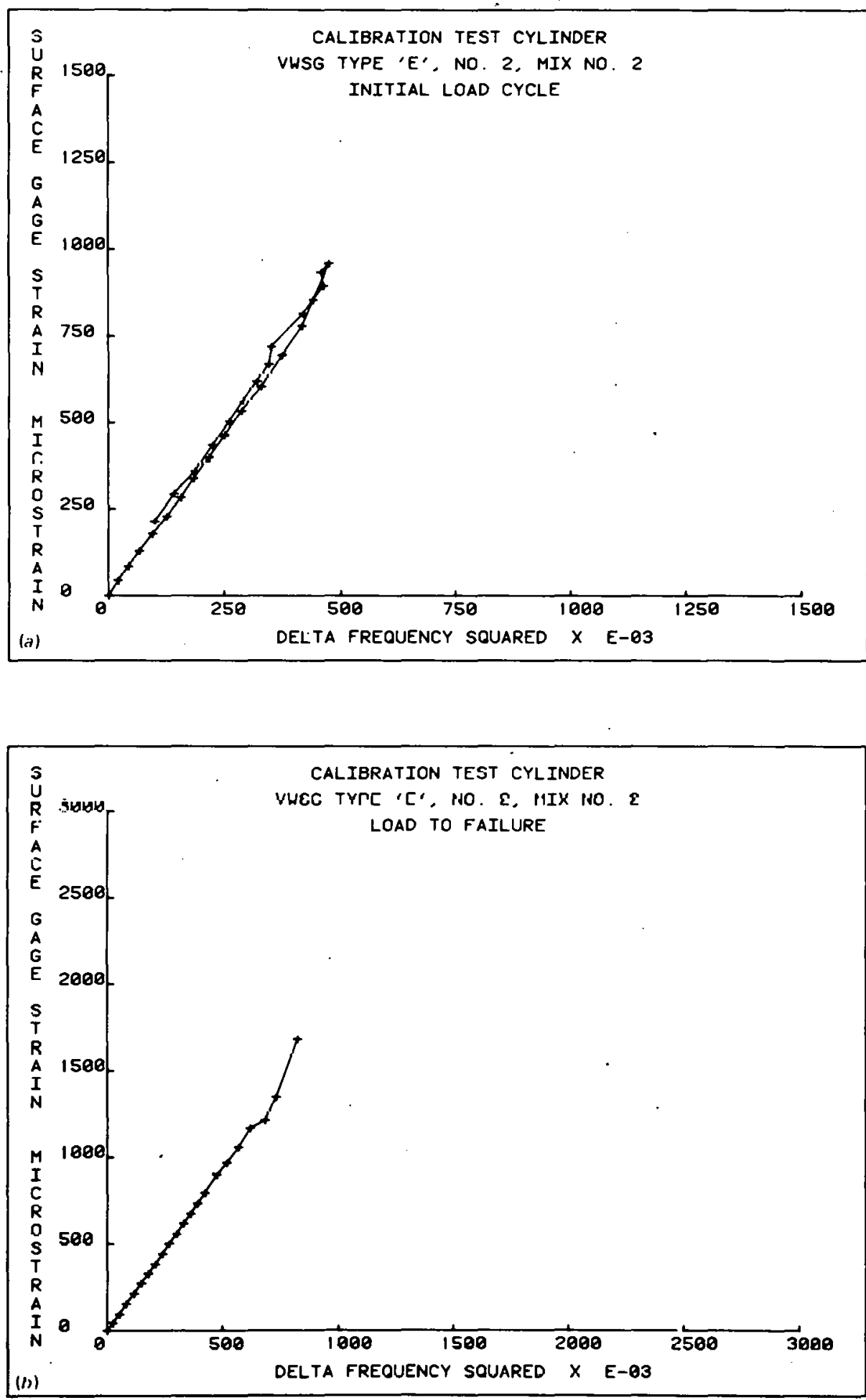

Fig. 66. Surface strain gage vs embedded gage output (VWSG, Type E, No. 2). 
ORNL-DWG 78-4509
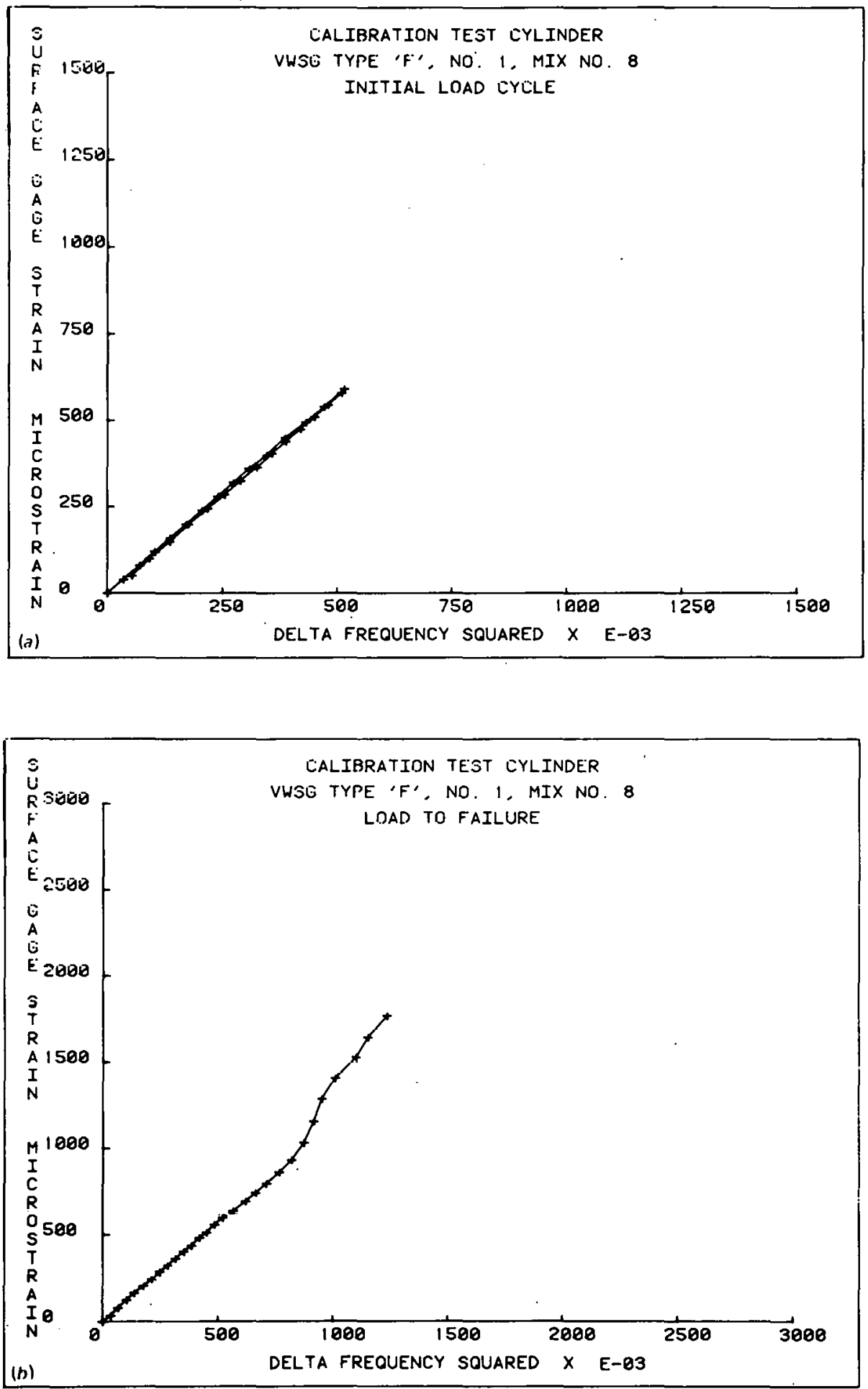

- Fig. 67. Surface strain gage vs embedded gage output (VWSG, Type F, No. 1). 
ORNL-DWG 78-4510
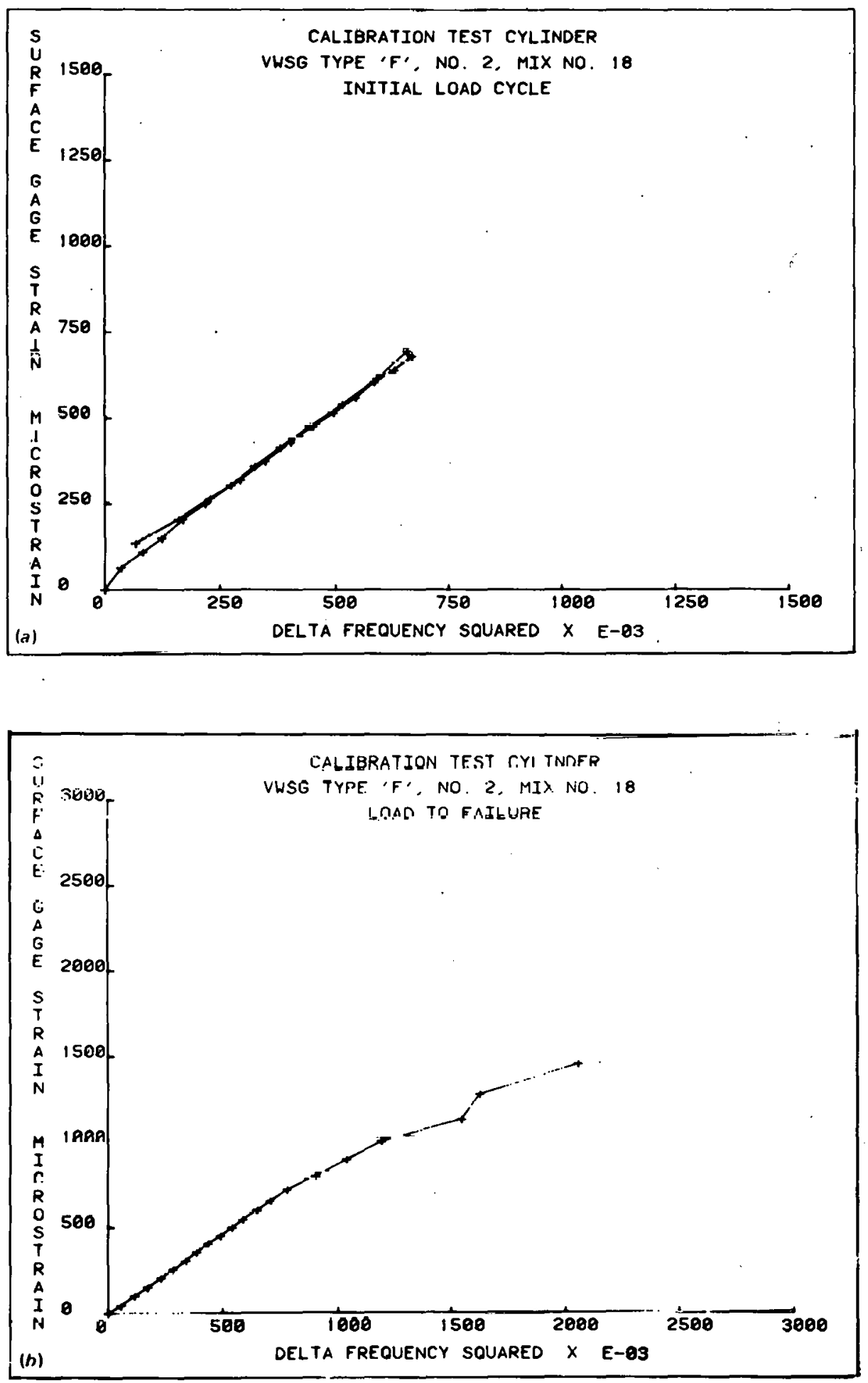

Fig. 68. Surface strain gage vs embedded gage output (VWSG, Typé F, No. 2). 
ORNL-DWG 78-4511
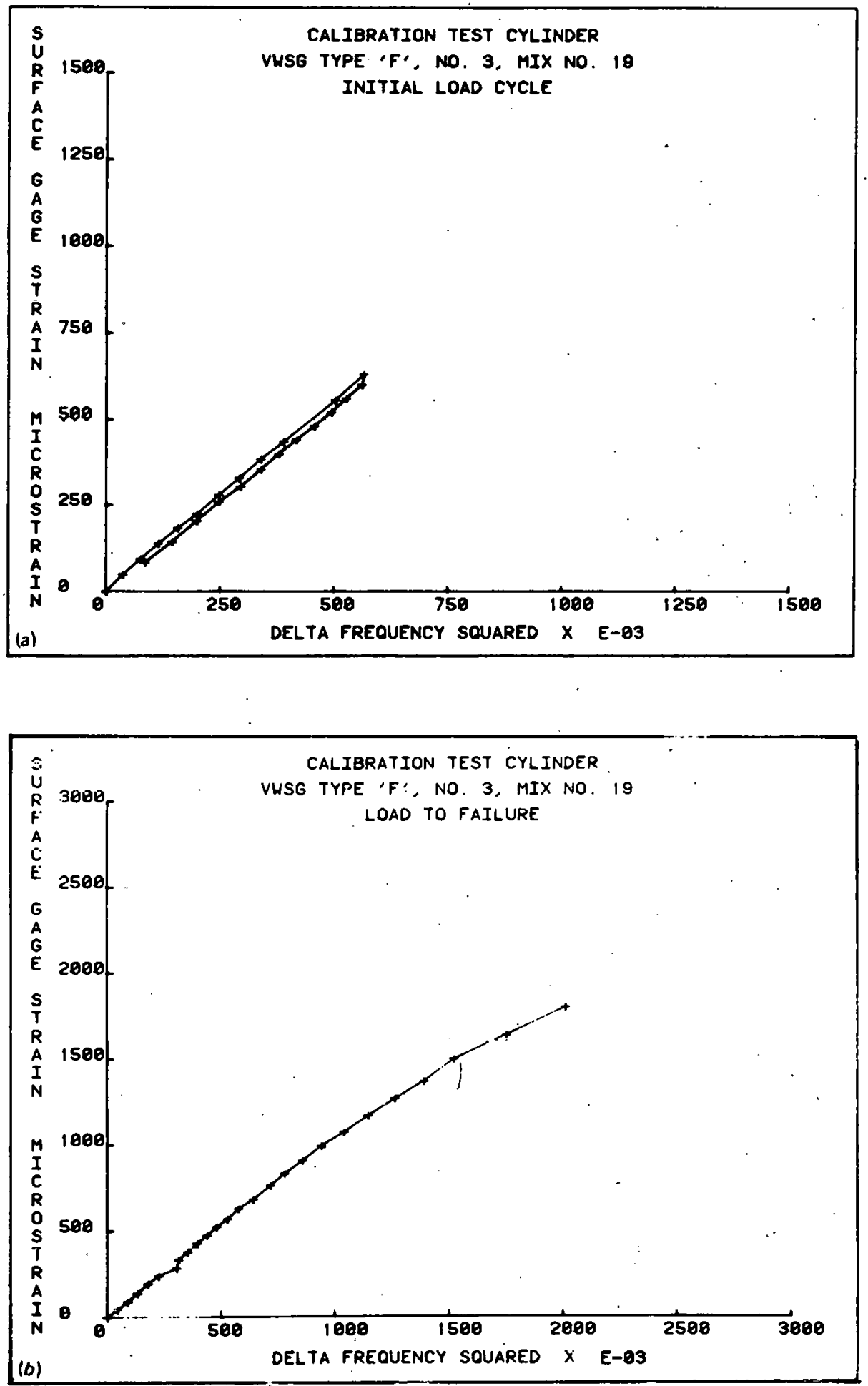

Fig. 69. Surface strain gage vs embedded gage output (VWSG, Type F, No. 3). 
ORNL-DWG 78-4512
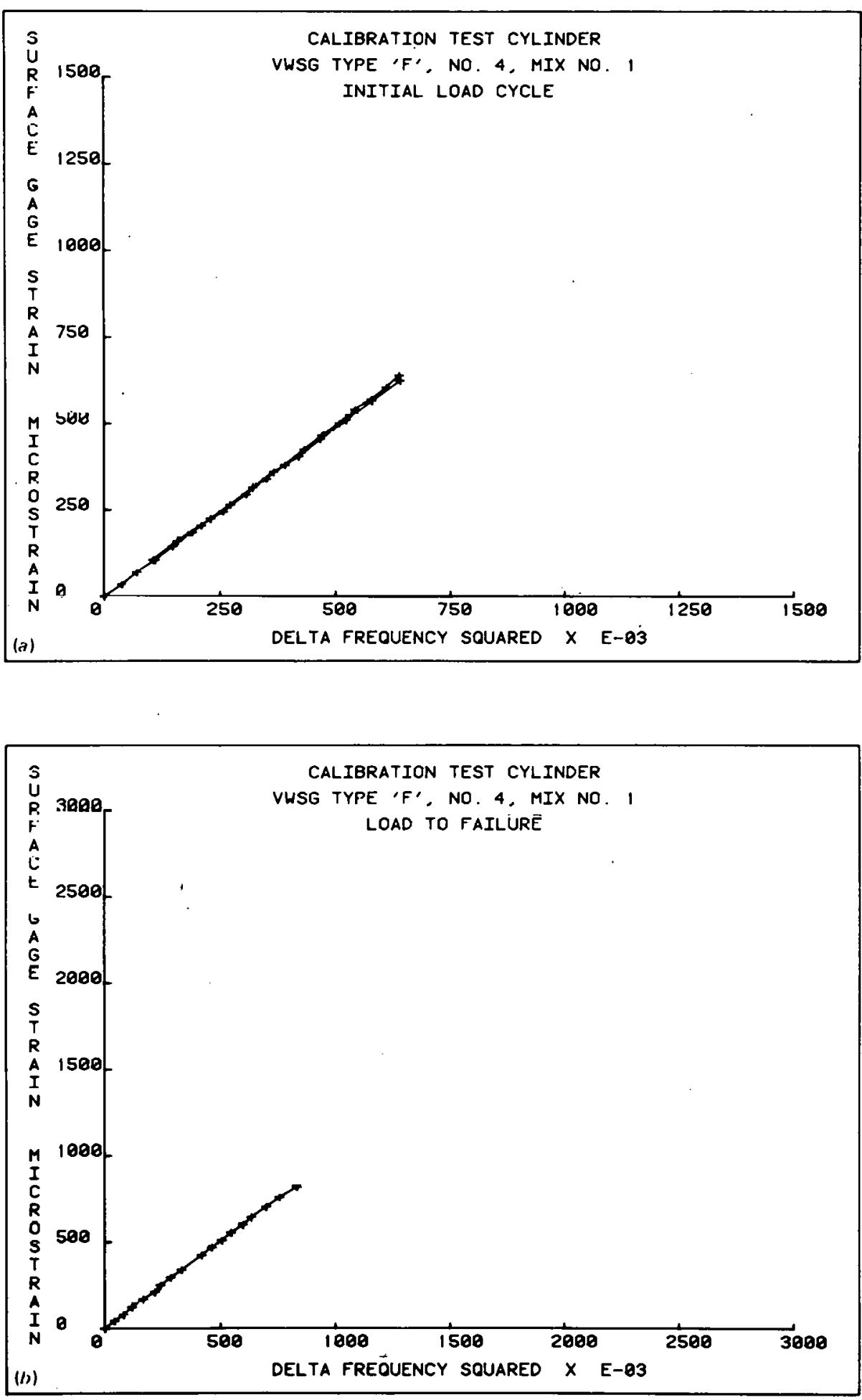

Fig. 70. Surface strain gage vs embedded gage output (VWSG, Type F, No. 4). 
ORNL-DWG 78-4513
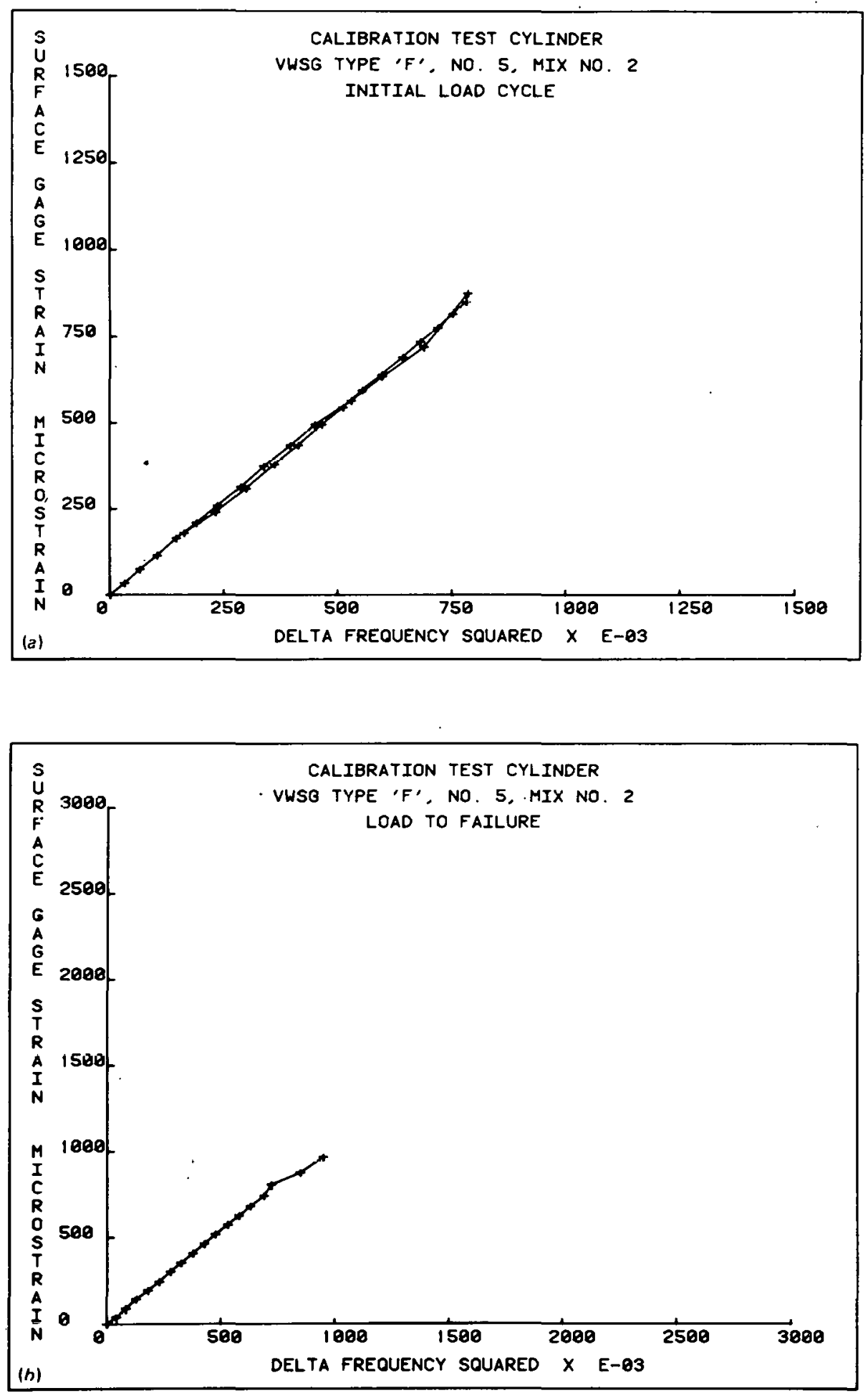
No. 5).

Fig. 71. Surface strain gage vs embedded gage output (VWSG, Type F, 
ORNL-DWG 78-4514
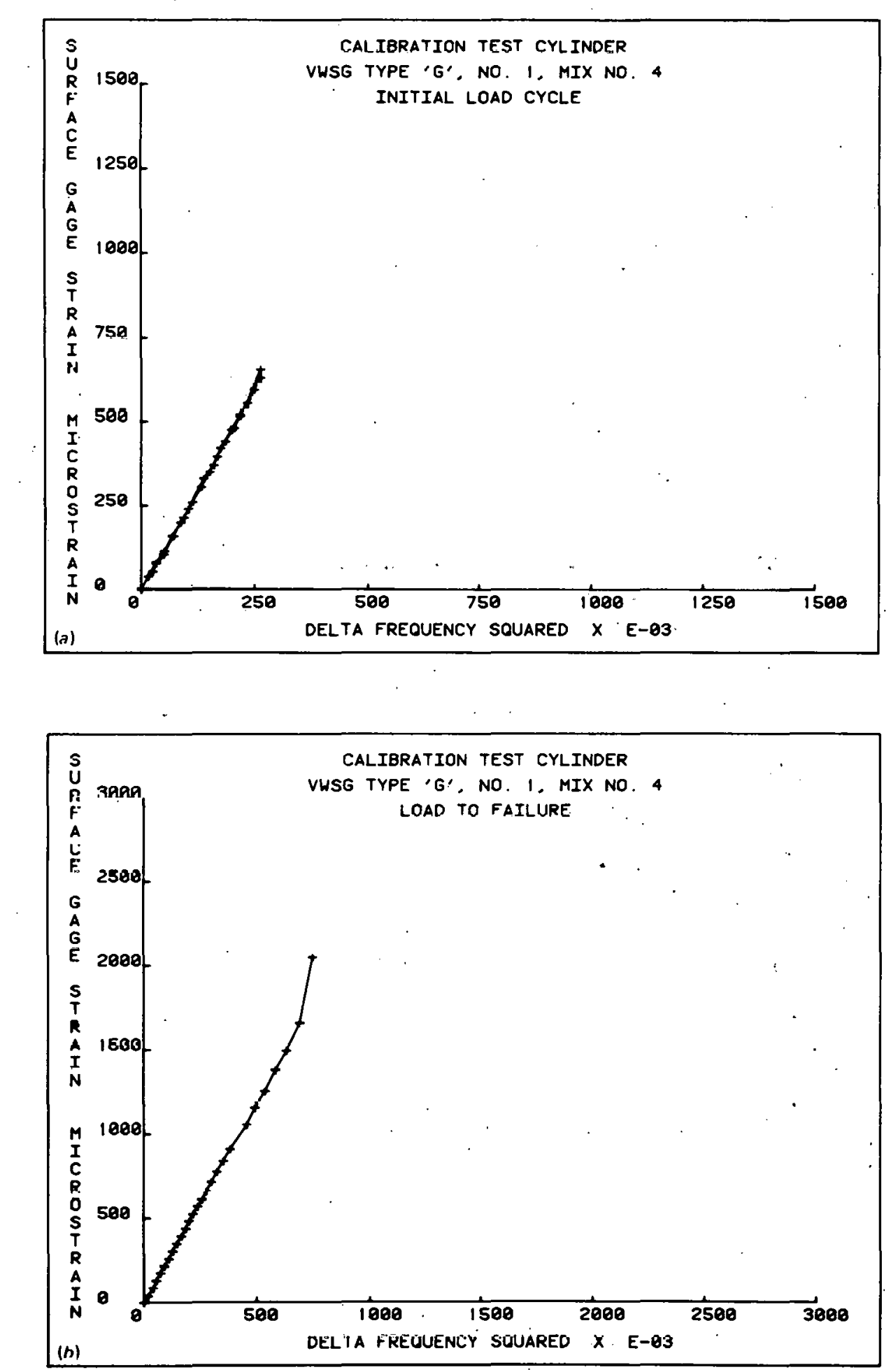
No. 1).

Fig. 72. Surface strain gage vs embedded gage output (VWSG, Type G, 
ORNL-DWG 78-4515
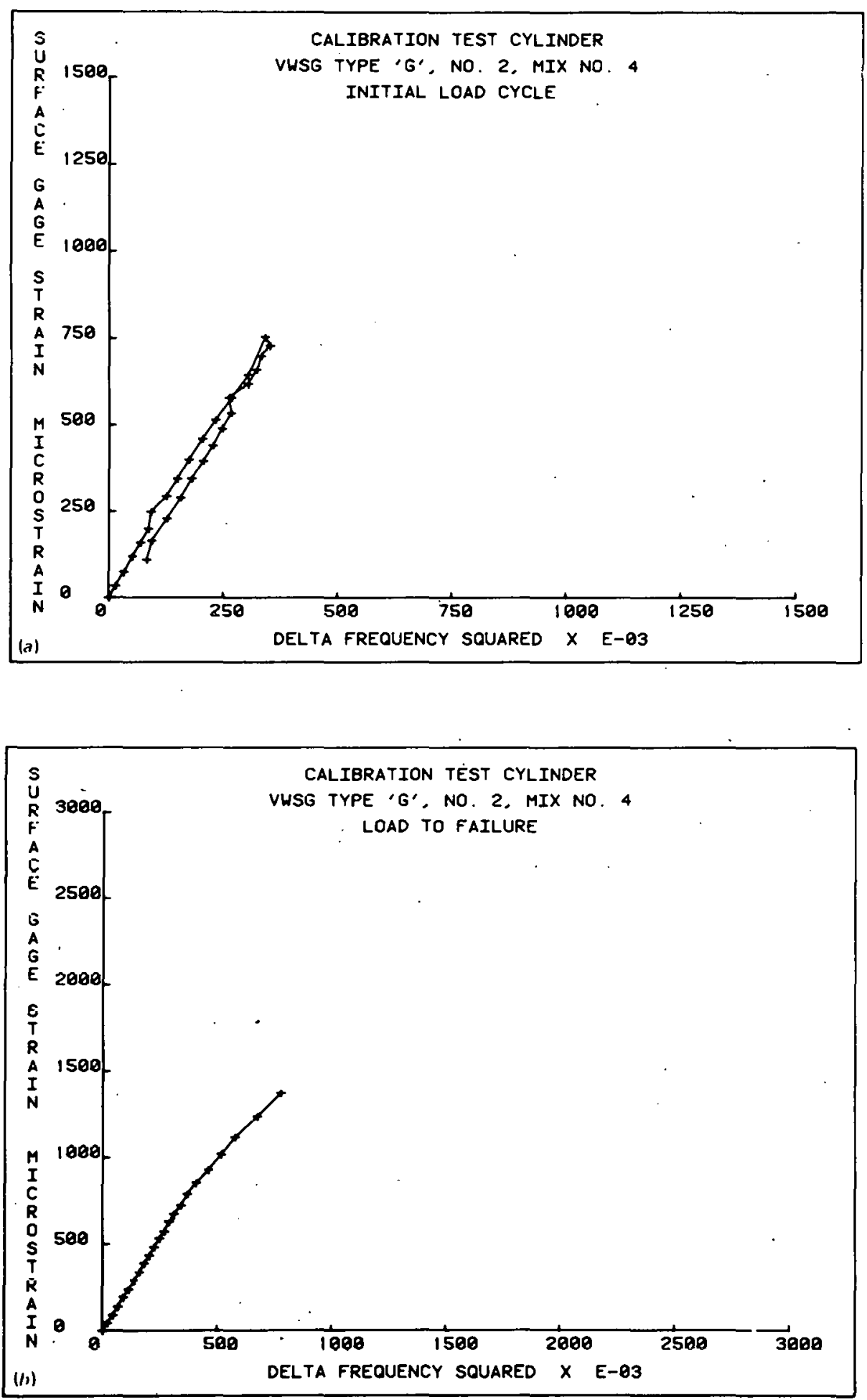

Fig. 73. Surface strain gage vs embedded gage output (VWSG, Type G, No. 2). 
ORNL-DWG 78-4516
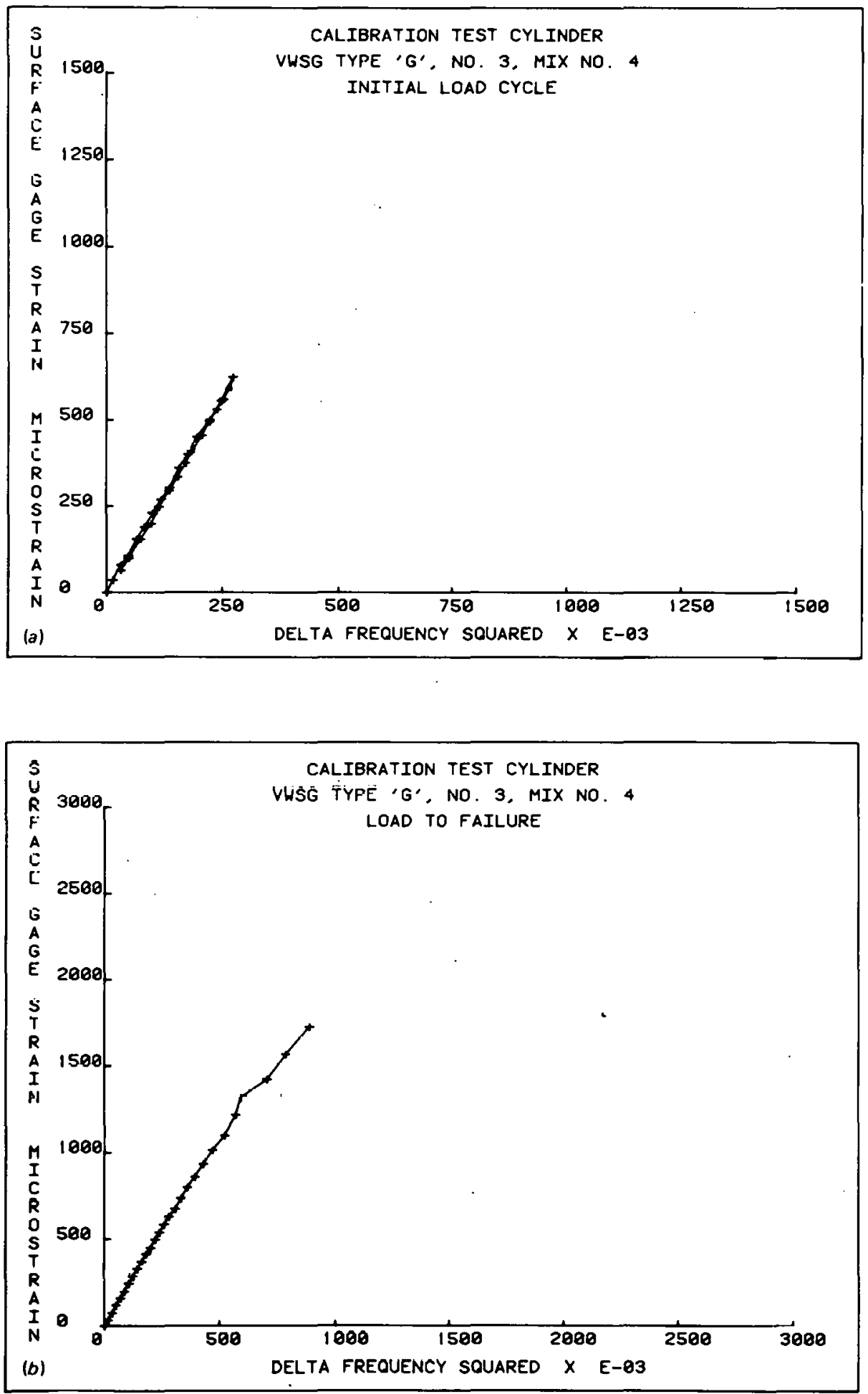

Fig. 74. Surface strain gage vs embedded gage output (VWSG, Type G, No. 3). 
ORNL-DWG 78-4517
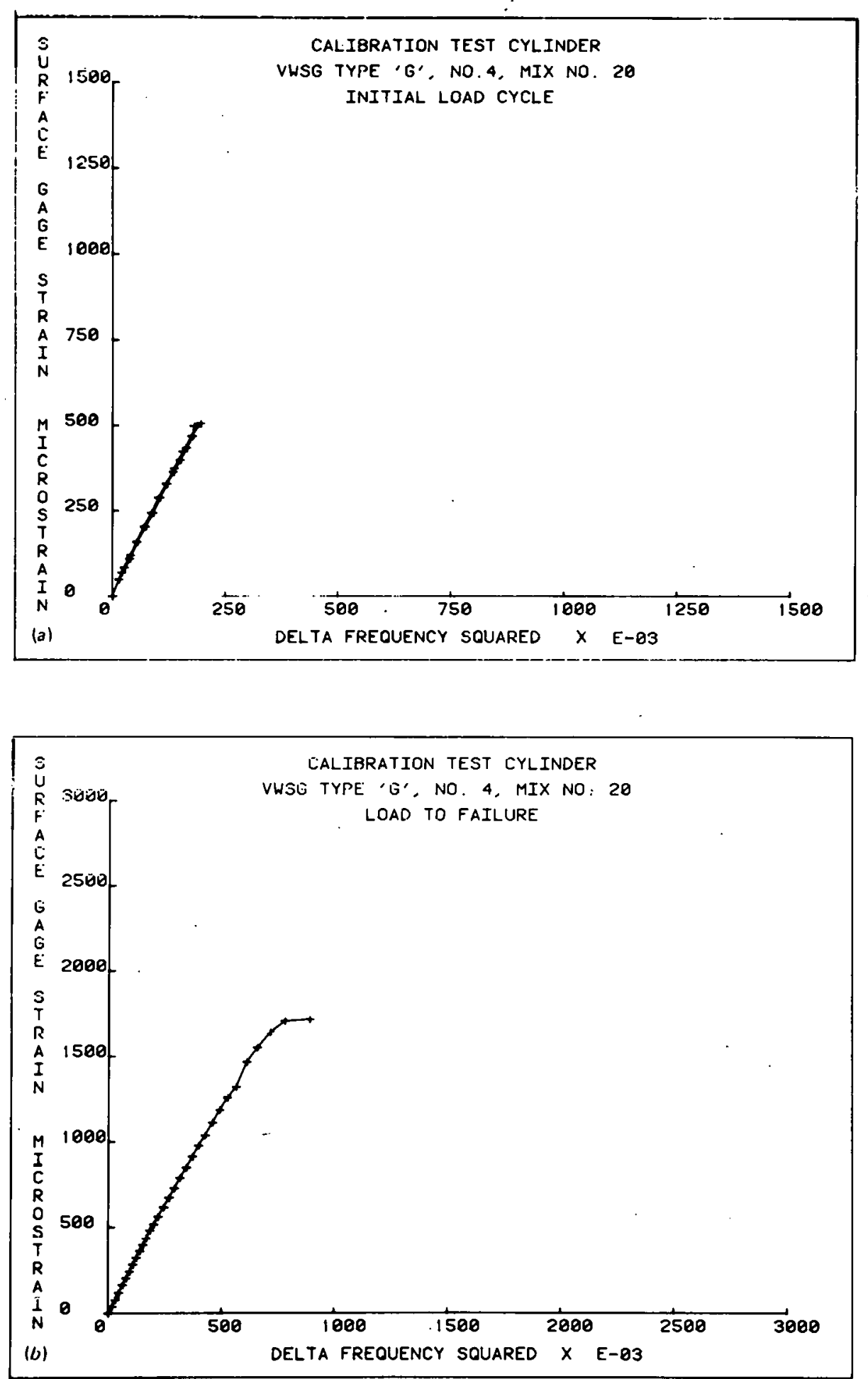

Fig. 75. Surface strain gage vs embedded gage output (VWSG, Type G, No, 4). 
ORNL-DWG 78-4518
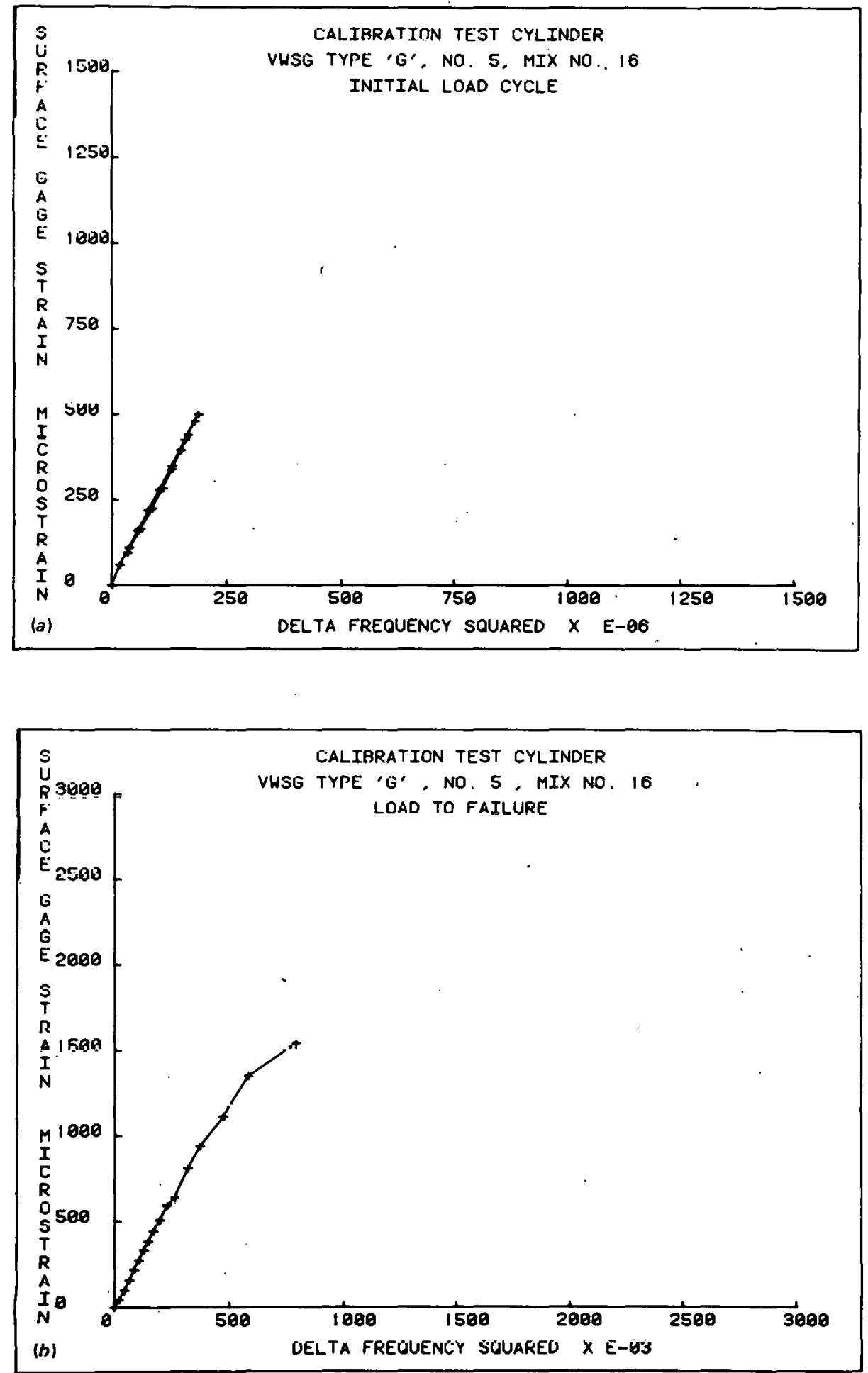

Fig. 76. Surface strain gage vs embedded gage output (VWSG, Type G, No. 5). 
ORNL-DWG 78-4519
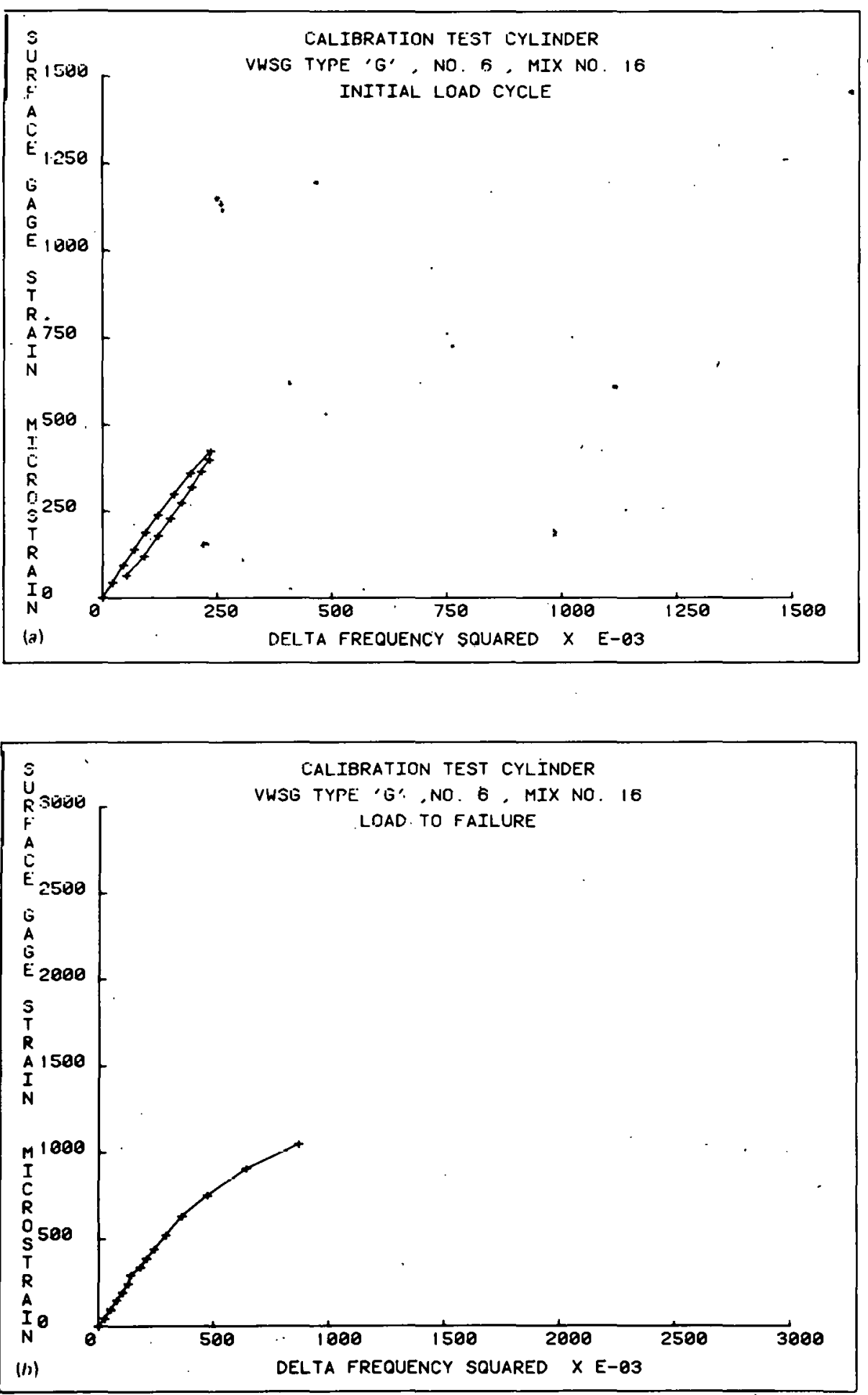

Fig. 77. Surface strain gage vs embedded gage output (VWSG, Type G, No. 6). 
ORNL-OWG 78-4520
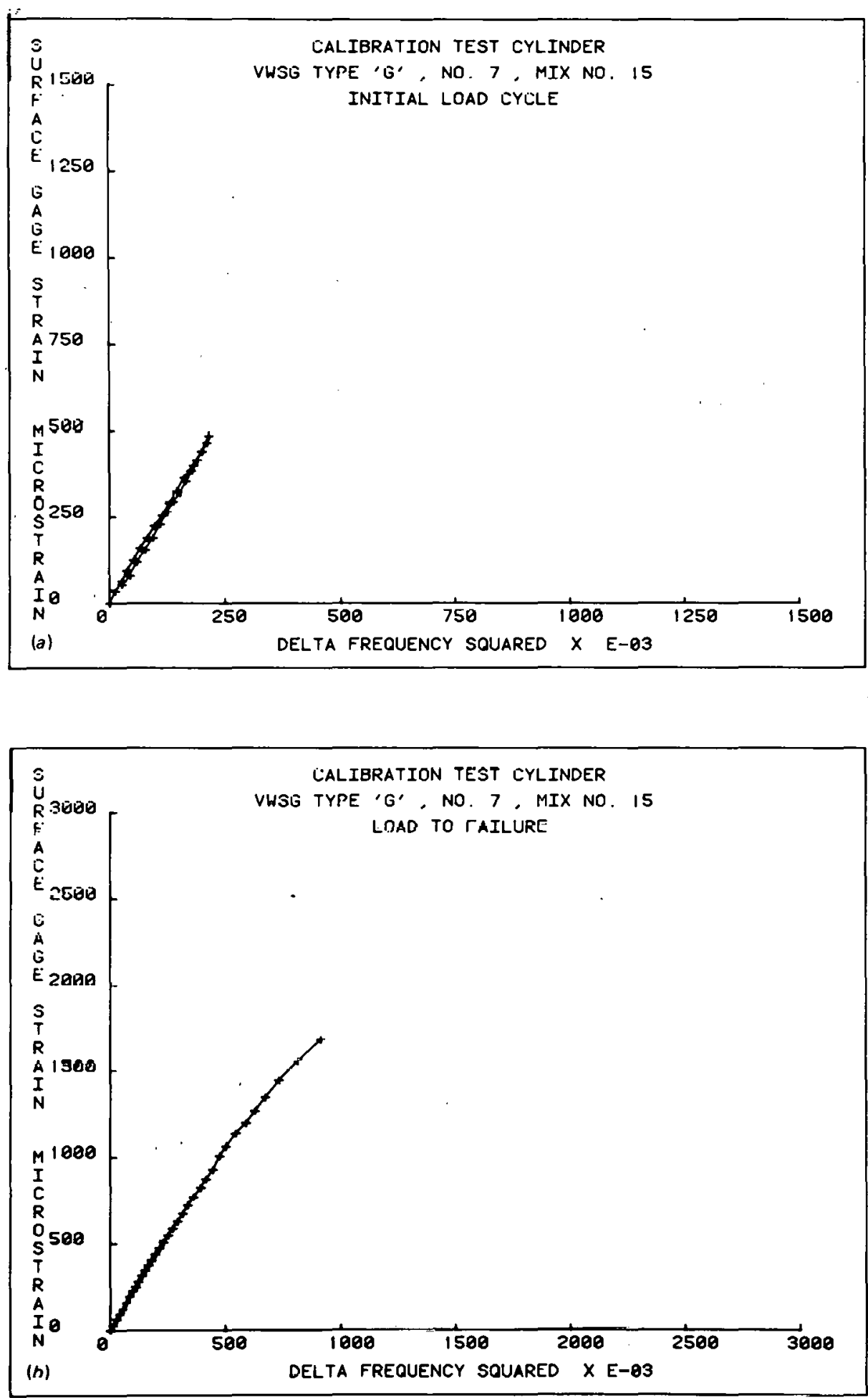

Fig. 78. Surface strain gage vs embedded gage output (VWSG, Type G, No. 7). 
ORNL-DWG 78-4521

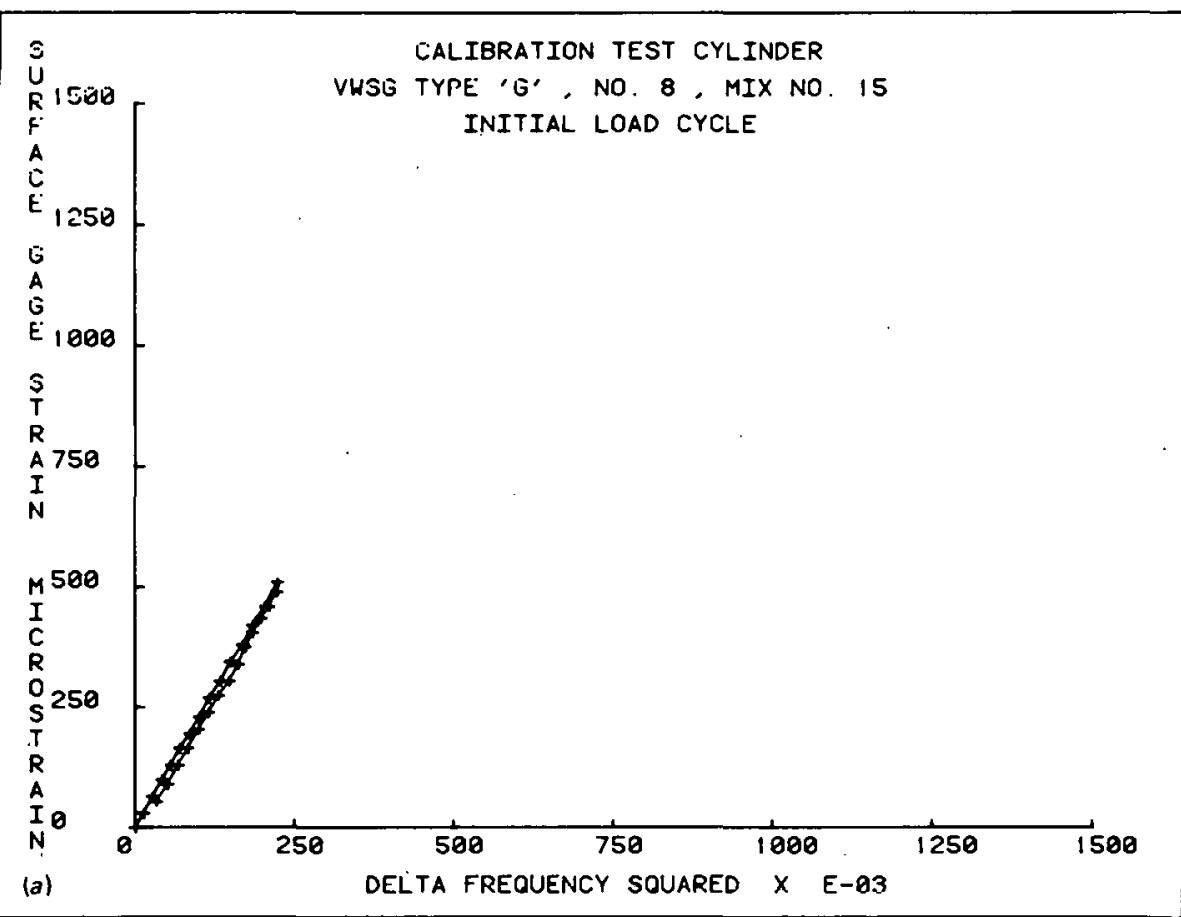

$\therefore$

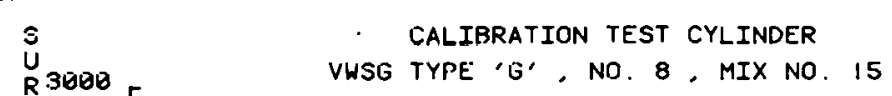

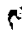

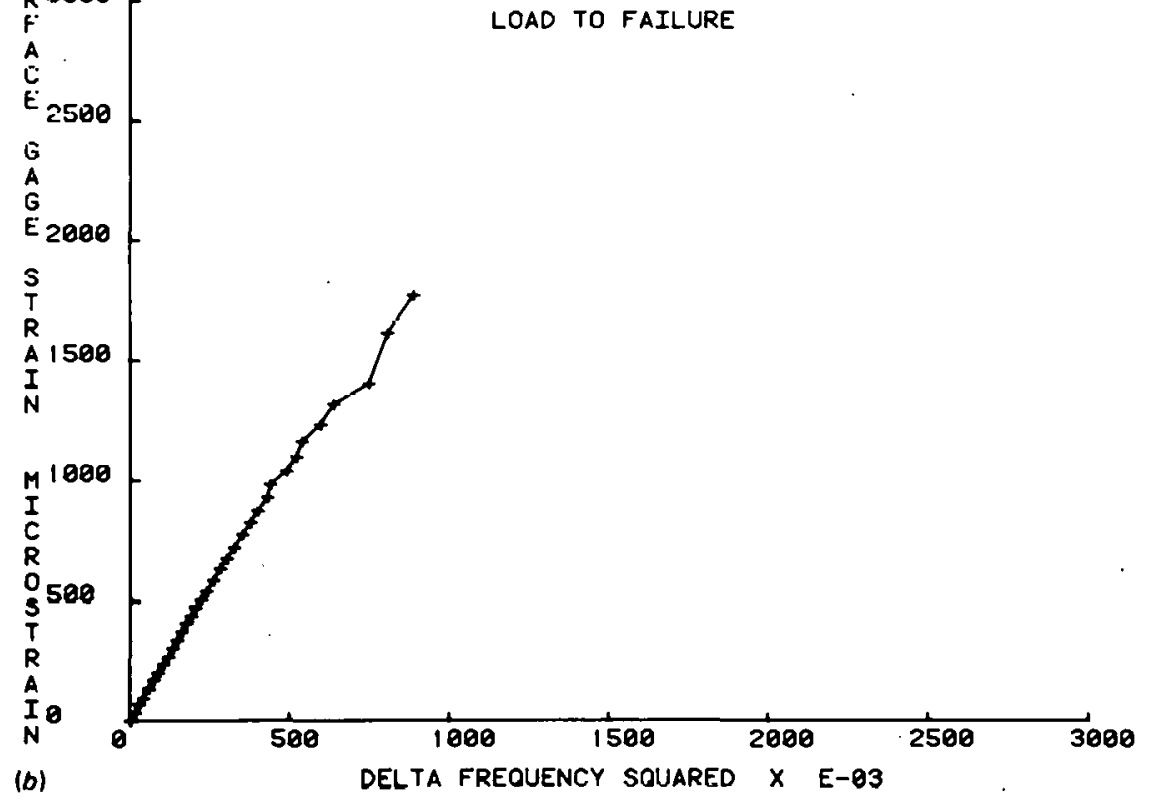

Fig. 79. Surface strain gage vs embedded gage output (VWSG, Type G, No. 8). 
ORNL-DWG 78-4522
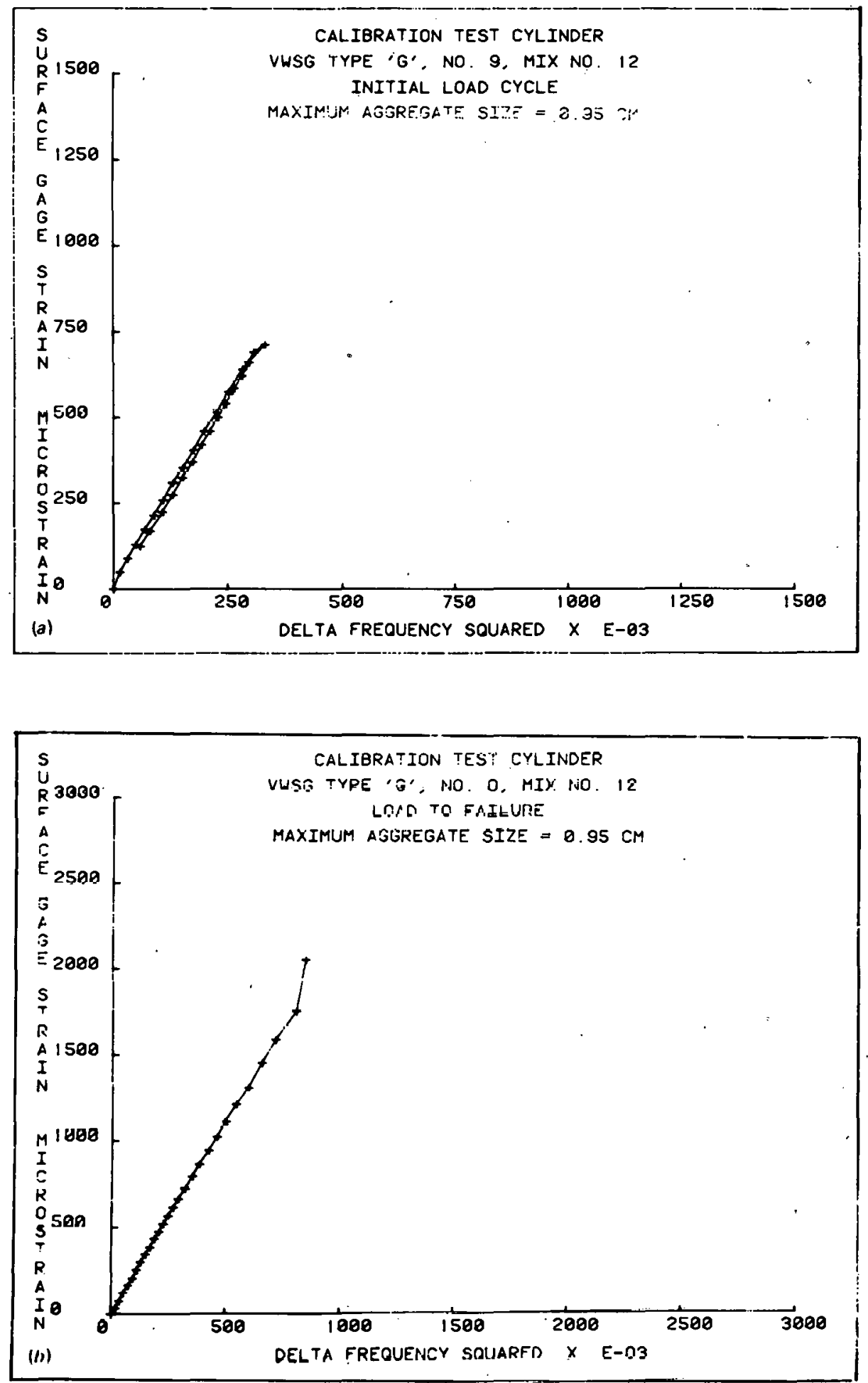
No. 9).

Fig. 80. Surface strain gage vs embedded gage output (VWSG, Type G, 
ORNL-DWG 78-4523
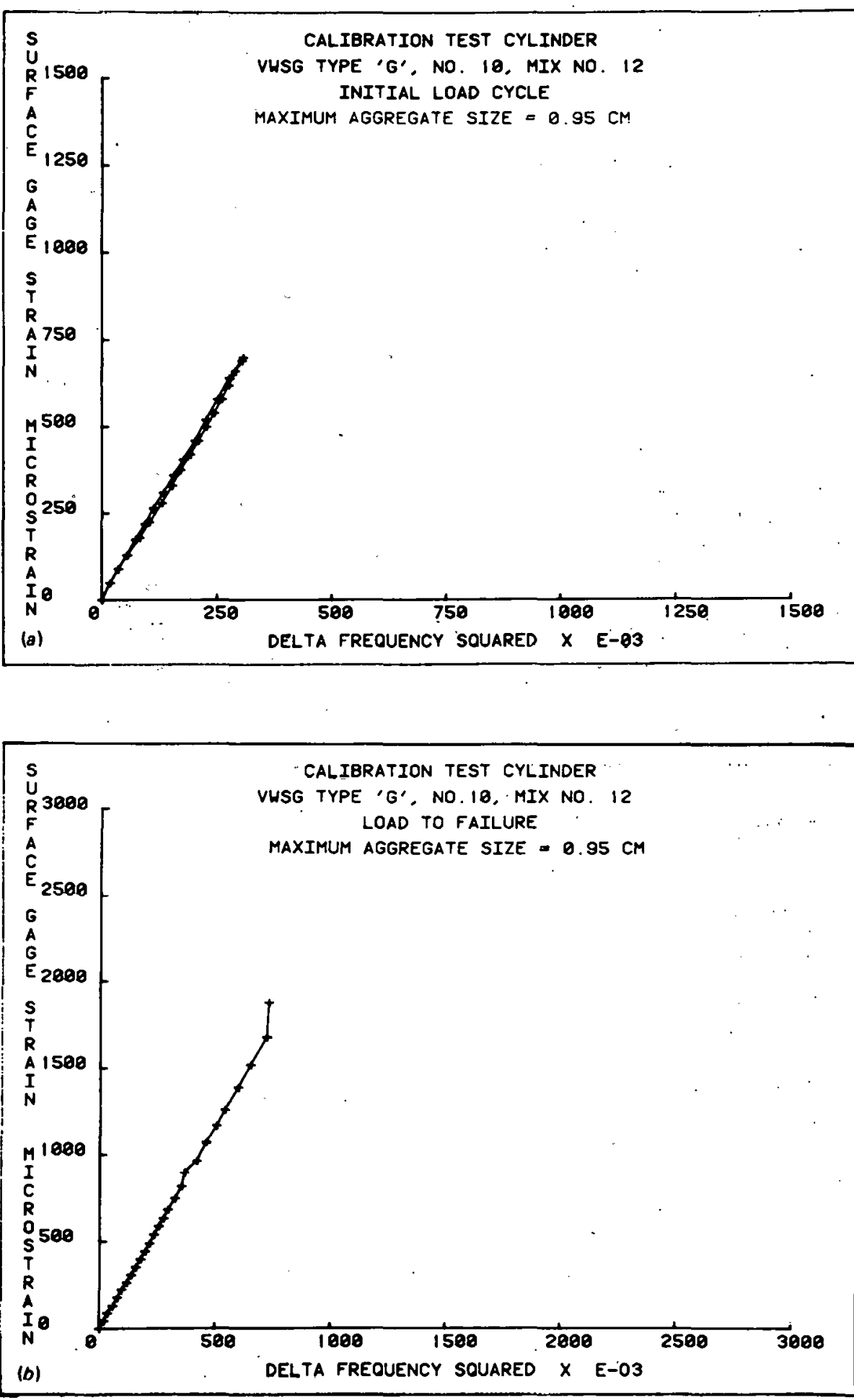

Fig. 81. Surface strain gage vs embedded gage output (VWSG, Type G, Nó. 10). 
ORNL-DWG 78-4524
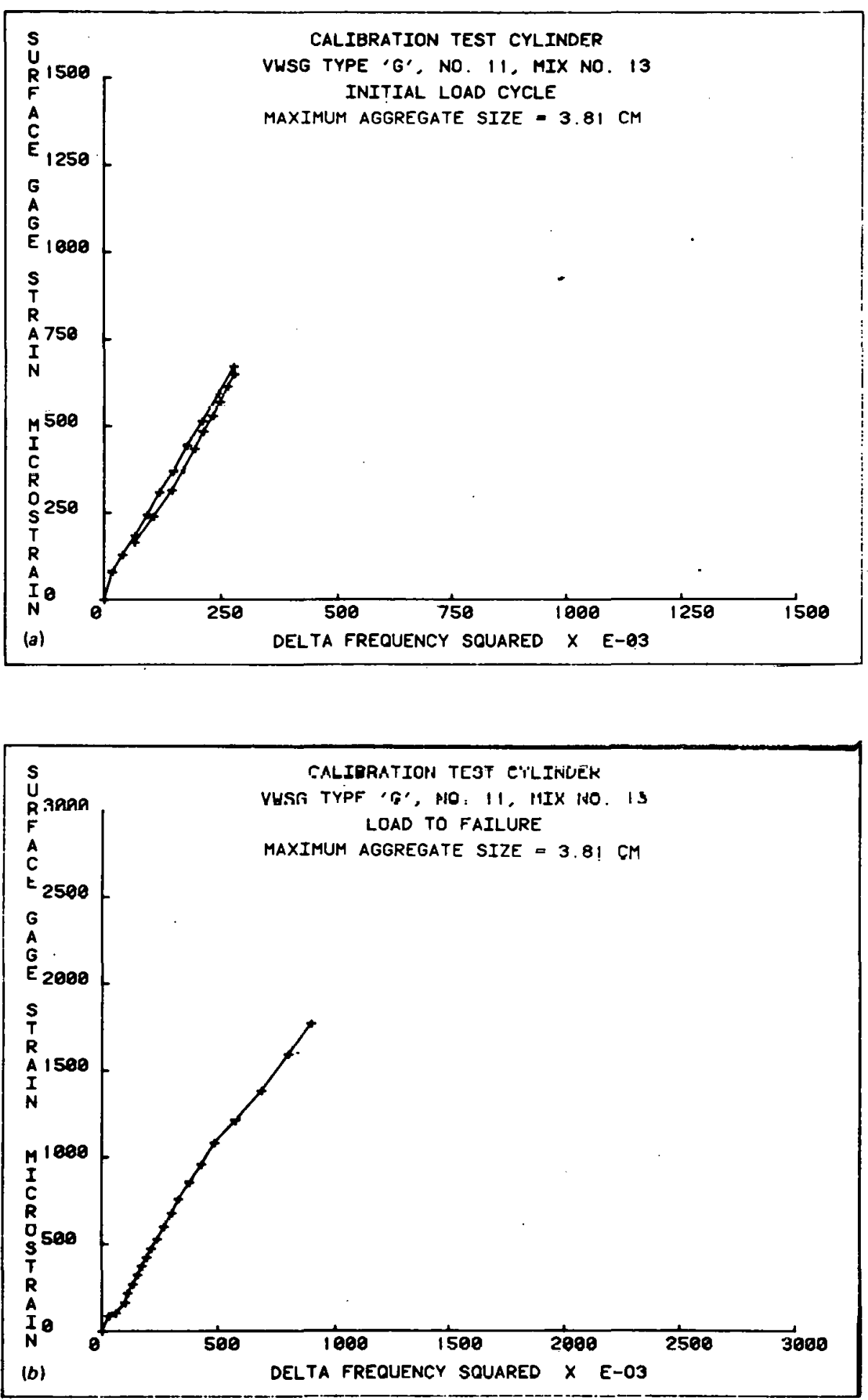

\section{$r$}

9

Fig. 82. Surface strain gage vs embedded gage output (VWSG, Type G, No. 11). 
ORNL-OWG 78-4525
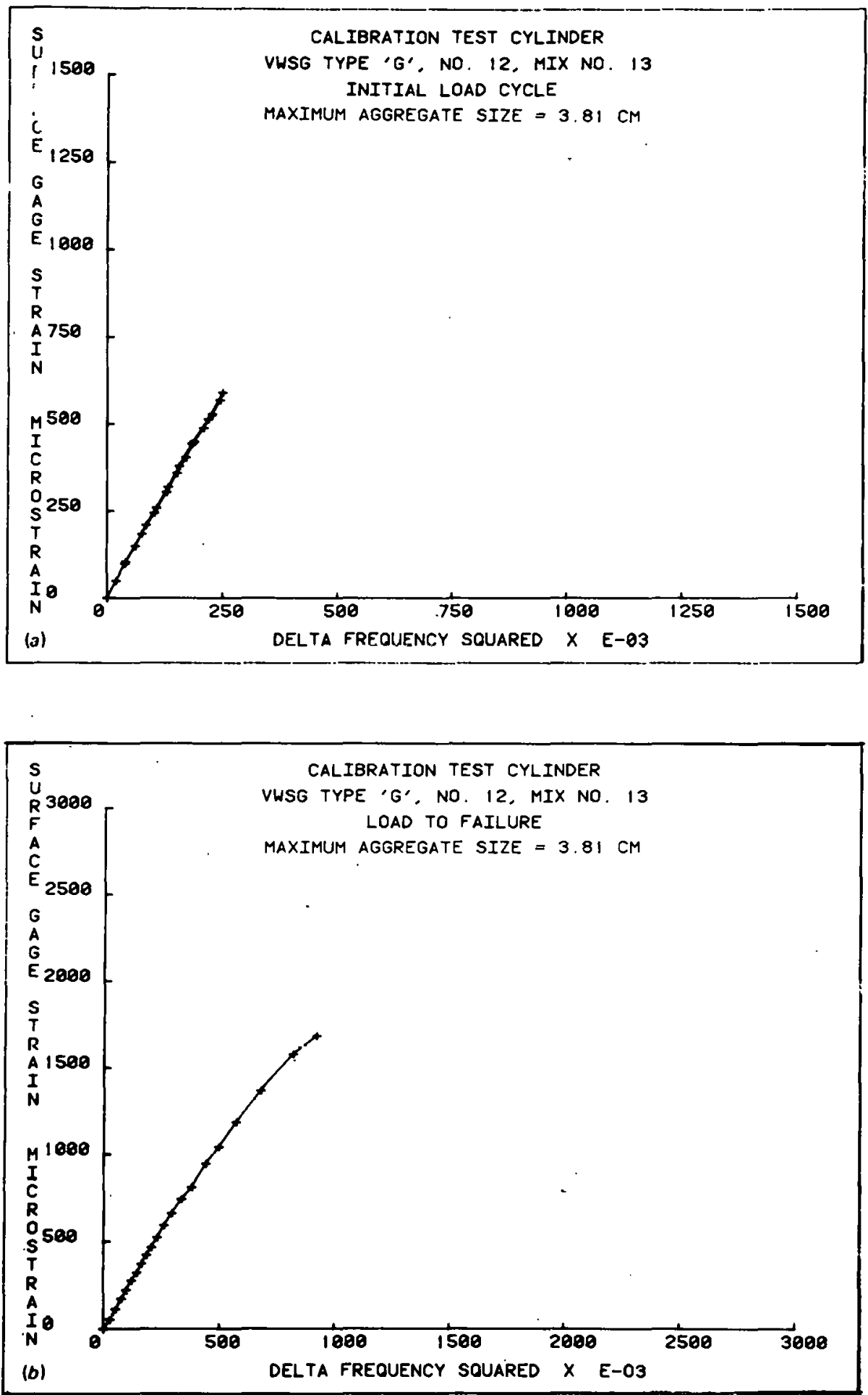

Fig. 83. Surface strain gage vs embedded gage output (VWSG, Type G, Nu. 12). 


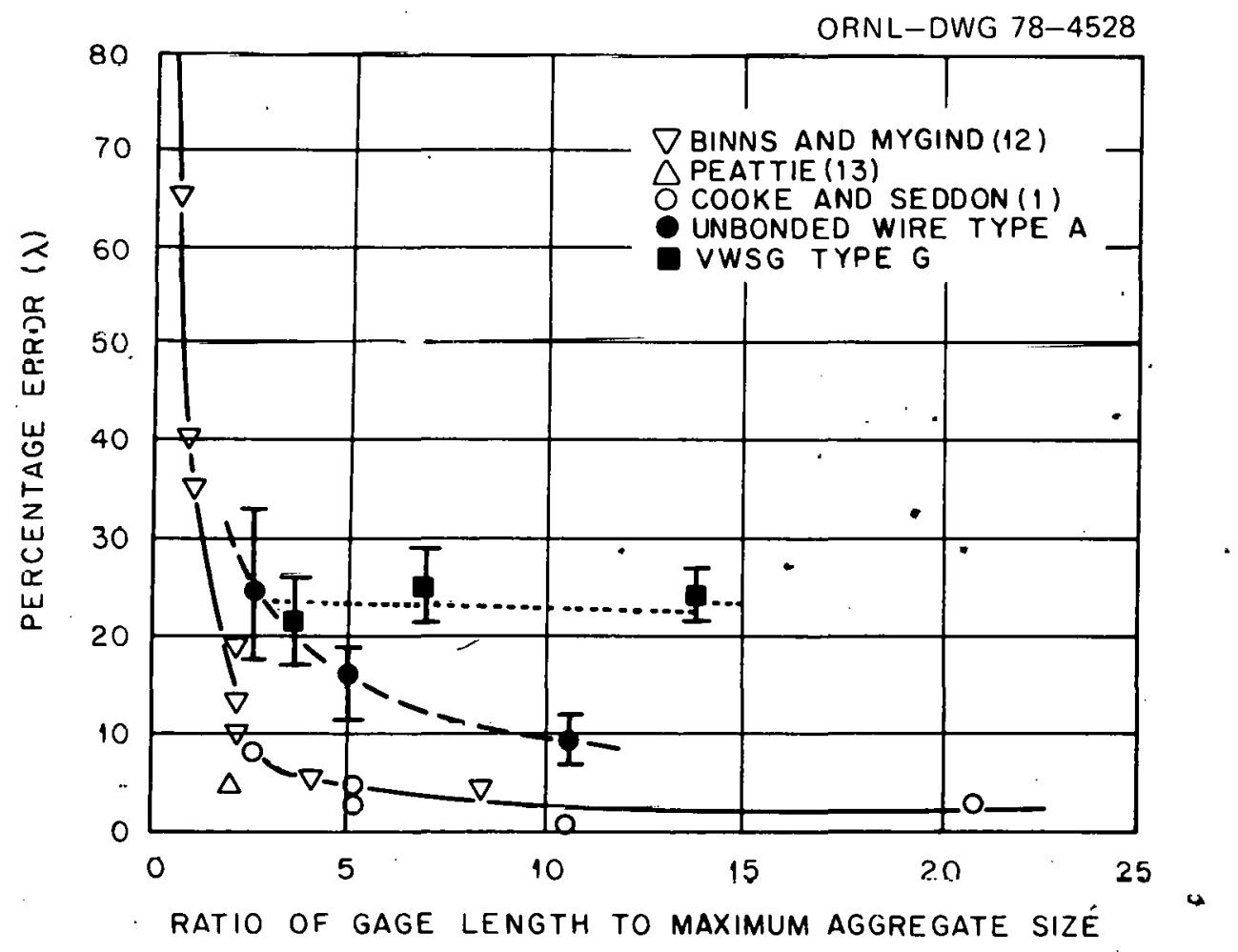

F1g. 84. Effect of ratio of gage length to maximum aggregate size on strain meter performance. 


\section{REFERENCES}

1. R. W. Cooke and A. E. Seddon, "The Laboratory Use of Bonded-Wire Electrical Resistance Strain Gauges on Concrete at the Building Research Station," Magazine of Concrete Research, 31-38 (March 1956).

2. V. Bertero et a1., "Instrumentation and Techniques for Study of Concrete Properties at Elevated Temperatures," American Concrete Institute Special Publication 34, Concrete for Nuclear Reactors (III), 1377-1419 (1972).

3. N. Hast, Measuring Stresses and Deformations in Solid Materials, Centraltryckercit, Stockholm, 1943.

4. J. Boussinesq, Application des potentiels à l'étude l'equilibre et du mouvement des solides élastiques, Gauthier-Villars, Paris, 1885.

5. Y. C. Loh, Internal Stress Gauges for Cementitious Materials, Report NR 064-331, Massachusetts Institute of Technology, Department of Civil and Sanitary Engineering, Cambridge, Mass. (July 1951).

6. H. G. Geymayer, Strain Meters and Stress Meters for Embedment in Models of Mass Concrete Structures, U.S. Army Engineer Waterways Experiment Station, Corps of Engineers, Vicksburg, Miss., pp. 1-58 (January 1968).

7. Private communication with Mr. Sullivan, U.S. Army Engineer Waterways Experiment Station, Corps of Engineers, Vicksburg, Mississippi, with D. J. Naus, ORNL, February 1975.

8. H. D. Morgan and K. R. McLachlan, "Some Recent Developments in the Design and Use of Strain Gages for Full-Scale Testing of Structures," Reunion Intermational des Laboratoires d'Essais et de Recherches sur les Materiaux et les Constmetions Symposium on the Conservation of Structures, Lisbon, 1955, Vol. II, pp. 870-84.

9. N. Mayer and U. Flesch, "A Fluidic Strain Measuring System for Prestressed Concrete Reactor Pressure Vessels," Paper A1, Proceedings of the 5th Cranfield Fluidics Conference, Uppsala, Sweden, June $13-16,1972$.

10. N. Czaika et a1., "Instrumentation for Use in Prestressed Concrete Reactor Pressure Vessels," Joumal for the Society for Experimental Stress Analysis, 82-88 (1974).

11. Private communication with Dr. G. Jüri Komendant, University of California, Berkeley, with D. J. Naus, ORNT, February 1978.

12. R. D. Binns and H. S. Mygind, "The Use of Electrical Resistance Strain Gauges, and the Effect of Aggregate Size on Gauge Length in Connection with the Testing of Concrete," Magazine of Concrete Research 1(1), 35-39 (1949). 
13. K. R. Peattie, "Tests on Concrete With Electrical Resistance Strain Gauges," Engineering 172(4472), 468 (October 1951). 
ORNL/TM-6191/V1

Dist. Category UC-77

\section{Internal Distribution}

\author{
1. S. J. Ball \\ 2. D. E. Bartine \\ 3. M. E. Bender \\ 4-9. J. P. Callahan \\ 10. D. A. Canonico \\ 1.1. .J. A. C.linard \\ 12. J. A. Conlin \\ 13. J. H. Coobs \\ 14. W. E. Cooper \\ 15. J. M. Corum \\ 16. J. R. DiStefano \\ 17. W. G. Dodge \\ 18. J. R. Dougan \\ 19. W. P. Eatherly \\ 20. D. N. Fanning \\ 21. Uri Gat \\ 22. D. W. Goodpasture \\ 23. A. G. Grindell \\ 24. W. L. Greenstreet \\ 25. R. C. Gwaltney \\ 26. J. F. Harvey \\ 27. F. J. Homan \\ 28-36. P. R. Kasten \\ 37. M. Levenson \\ 38. A. L. Lotts \\ 39. R. E. MacPherson
}

40. A. P. Malinauskas

41. W. J. McAfee

42. J. G. Merkle

43. R. K. Nanstad

44-53. D. J. Naus

54. K. J. Notz

55. C. B. Oland

56. H. Postma

57. G. C. Robinson

58. J. P. Sanders

59. M. R. Sheldon

60. G. M. Slaughter

61. G. C. Smith

62. J. E. Smith

63. H. E. Tramme11

64. M. Tobias

65. D. B. Trauger

66. J. R. Weir, Jr.

67. G. D. Whitman

68. R. P. Wichner

69. G. T. Yahr

70. ORNL Patent Office

71-72. Central Research Library

73. Document Reference Section

74-78. Laboratory Records Department

79. Laboratory Records, ORNL-RC

\section{Consultants and Subcontractors}

80. E. G. Burdette, Civil Engineering Department, University of Tennessee, Knoxville, TN 37916

81. R. H. Gallagher, Civil Engineering Department, Cornell University, Ithaca, NY 14850

\section{Externa1 Distribution}

82-83. Director, Division of Nuclear Research and Applications, DOE, Washington, D.C. 20545

84. Director, Reactor Division, DOE-ORO

85-86. Director, Research and Technical Support Division, DOE-ORO

87-263. For distribution as shown in TID-4500 under category UC-77, Gas-Cooled Reactor Technology 